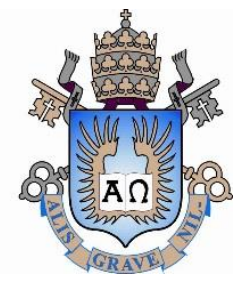

Luisa Fernanda Rivera Criollo

\title{
Monitoramento e avaliação da regulamentação sobre rotulagem de alimentos alergênicos no Brasil: proposição de indicadores e métricas
}

Dissertação de Mestrado

Dissertação apresentada como requisito parcial para obtenção do título de Mestre pelo Programa de Pós-Graduação em Metrologia (Área de concentração: Metrologia para Qualidade e Inovação) da PUC-Rio.

Orientadores: Profa. Maria Fatima Ludovico de Almeida Prof. Rodrigo Flora Calili 


\section{Pontifícia Universidade Católica $_{\text {a }}$}

Luisa Fernanda Rivera Criollo

\section{Monitoramento e avaliação da regulamentação sobre rotulagem de alimentos alergênicos no Brasil: proposição de indicadores e métricas}

Dissertação apresentada como requisito parcial para obtenção do título de Mestre pelo Programa de PósGraduação em Metrologia (Area de concentração: Metrologia para Qualidade e Inovação) da PUC-Rio. Aprovada pela Comissão Examinadora abaixo assinada.

Profa. Maria Fatima Ludovico de Almeida

Orientadora

Programa de Pós-Graduação em Metrologia - PUC-Rio

Prof. Rodrigo Flora Calili Co-orientador Programa de Pós-Graduação em Metrologia - PUC-Rio

Profa. Maria Angela Campelo de Melo Departamento de Administração (IAG) - PUC-Rio

Profa. Stella Regina Reis da Costa Universidade Federal Rural do Rio de Janeiro

Prof. Marcio da Silveira Carvalho

Coordenador Setorial do Centro

Técnico Científico - PUC-Rio

Rio de Janeiro, 24 de junho de 2016 
Todos os direitos reservados. É proibida a reprodução total ou parcial do trabalho sem autorização da universidade, do autor e do orientador.

\section{Luisa Fernanda Rivera Criollo}

Graduou-se em Engenharia de Alimentos pela Universidad Agraria de Colômbia em 2013. Mestranda do Programa de Pós-Graduação em Metrologia da PUC-Rio

Ficha Catalográfica

Criollo, Luisa Fernanda Rivera

Monitoramento e avaliação da regulamentação sobre rotulagem de alimentos alergênicos no Brasil: proposição de indicadores e métricas/ Luisa Fernanda Rivera Criollo; Orientadora: Maria Fatima Ludovico de Almeida; Coorientador: Rodrigo Flora Calili - 2016.

116 f. : il. (color.) ; $30 \mathrm{~cm}$

Dissertação (mestrado) - Pontifícia Universidade Católica do Rio de Janeiro, Programa de Pós-Graduação em Metrologia, 2016.

Inclui bibliografia.

1. Metrologia - Teses. 2. Regulamentação. 3. Segurança de alimentos. 4. Rotulagem de alimentos alergênicos. 5. Monitoramento e avaliação. 6. Indicadores e métricas. 7. Métodos multicritério de apoio à decisão. I. Almeida, Maria Fatima Ludovico de. II. Calili, Rodrigo Flora. III. Pontifícia Universidade Católica do Rio de Janeiro. Programa de Pós-Graduação em Metrologia para a Qualidade e Inovação. IV. Título.

CDD: 389.1 
A mi mamá Susana Eugenia Criollo y a mi papá Julio Cesar Rivera por todo su amor, ejemplo y apoyo incondicional, motivándome y creyendo siempre en mí y en mis sueños, los amo. 


\section{Agradecimentos}

A Deus e à Maria que são minha fonte de fé, porque iluminam meu caminho para sempre sair adiante em busca de meu sonhos e da minha felicidade.

A meu pais Susana Eugenia Criollo e Julio Cesar Rivera pelo infinito amor e apoio incondicional; Sempre me incentivaram para cumprir minhas metas e acreditaram em mim sempre. Obrigada pelos ensinamentos e seu exemplo, que a cada dia fazem de mim uma pessoa melhor.

A minha irmã Diana Maria por seus conselhos, amor, apoio e motivação. Tiveram momentos que só ela sabia me entender...

A meu sobrinho Juan Pablo, meu amor chiquito, que amo e adoro como se fosse meu!! o melhor que tem acontecido nesses últimos nove anos.

A meu companheiro de vida, meu namorado e príncipe azul Juan Pablo, pelo infinito amor, paciência, compreensão e apoio incondicional, que acreditou em mim e me escolheu como sua companheira de travessia. Muito obrigada por me fazer acreditar no amor verdadeiro, cheio de sobressaltos, mas sempre pensando que podemos muito mais do que imaginamos. Esta é uma vitória de nós dois!

A meus sogros Dona Paty e Don Gabriel, pela ajuda, apoio e motivação para sempre sair adiante vitoriosos. Também a minhas cunhadas Caro e Pao, muito obrigada por sua linda amizade.

A minha orientadora Professora Fatima Ludovico pela excelente orientação, ajuda e confiança depositada em mim, por compartilhar comigo seu amplo conhecimento com a melhor disposição. Obrigada por sempre procurar o melhor para nosso trabalho sem economizar esforços. A meu co-orientador Professor Rodrigo Calili, pelo apoio e contribuição neste trabalho.

Aos Professores e à equipe do Programa de Pós-graduação em Metrologia (Pos-MQI), em especial ao Professor Mauricio Frota pela oportunidade que me deu, acreditando no meu potencial desde o primeiro momento. Às secretarias Marcia e Paula, pela inigualável ajuda e excelente trabalho. Sempre foram pessoas 
muito amáveis e pacientes.

À Capes e à PUC-Rio pelo apoio financeiro.

À minha querida amiga Monica pela amizade, companhia, compressão, apoio, cumplicidade, conselhos, brincadeiras e até brigas...só tenho palavras de gratidão para você.

A meus colegas e amigos de mestrado, Cristiane e Ian, pela amizade, apoio e motivação e a Jose Daniel e Khrissy pelos conselhos e ajuda em Estatística e Português.

A meus amigos colombianos Lore, Dalma, Dilia, Magui, Leidy Marito, Renato, Jonh e Elioti, por sua amizade, ajuda e compressão nos momentos difíceis longe de minha família.

A meus vizinhos e amigos, Raquel e Jorge, por toda sua ajuda e apoio.

A todos, que de alguma forma contribuíram para a realização desta dissertação, meus agradecimentos sinceros. 


\section{Resumo}

Criollo, Luisa Fernanda Rivera; Almeida, Maria Fatima Ludovico de (Orientadora); Calili, Rodrigo Flora (Co-orientador). Monitoramento e avaliação da regulamentação sobre rotulagem de alimentos alergênicos no Brasil: proposição de indicadores e métricas. Rio de Janeiro, 2016. 116 p. Dissertação de Mestrado - Programa de Pós-Graduação em Metrologia. Área de concentração: Metrologia para Qualidade e Inovação, Pontifícia Universidade Católica.

O objetivo da dissertação é propor um conjunto de indicadores e métricas para o monitoramento e avaliação da regulamentação sobre rotulagem de alimentos alergênicos no Brasil, após sua implementação. No contexto institucional no qual a pesquisa se insere, considera-se que esse esforço propiciará ao órgão regulador, bem como aos diversos atores envolvidos na implementação da regulamentação em foco, o ferramental adequado para o monitoramento e a avaliação pretendida. A pesquisa pode ser considerada aplicada, descritiva e metodológica. Quanto aos meios de investigação, foi usado o método de construção de indicadores proposto pelo Ministério do Planejamento, Orçamento e Gestão, integrado a dois métodos de apoio à decisão: método analítico hierárquico (AHP) para definição dos pesos dos critérios classificatórios e a técnica TOPSIS para hierarquização dos indicadores propostos por categoria de requisitos da regulamentação, a partir dos graus atribuídos pelos especialistas. Destacam-se como resultados: a ferramenta de seleção e classificação de indicadores; e um conjunto consistente de indicadores de MA, visando à melhoria contínua do processo da regulamentação em foco e a comunicação do desempenho do órgão regulador neste campo da segurança de alimentos.

\section{Palavras-chave}

Metrologia; regulamentação; segurança de alimentos; rotulagem de alimentos alergênicos; monitoramento e avaliação; indicadores e métricas; métodos multicritério de apoio à decisão. 


\section{Abstract}

Criollo, Luisa Fernanda Rivera; Almeida, Maria Fatima Ludovico de (Advisor); Calili, Rodrigo Flora (Co-advisor). Monitoring and evaluation of food allergenic labeling regulation in Brazil: a proposal of indicators and metrics. Rio de Janeiro, 2016. 116 p. MSc. Dissertation - Programa de Pós-Graduação em Metrologia. Área de concentração: Metrologia para Qualidade e Inovação, Pontifícia Universidade Católica.

The objective of this dissertation is to propose a set of indicators and respective metrics for monitoring and evaluating (ME) the food allergenic labeling regulation in Brazil, after its implementation. Within the institutional context in which the research is situated, it is assumed that this effort will provide the regulatory agency as well as the various actors involved in the implementation of the focused regulation, the proper tools for monitoring and evaluating its regulatory results. This research can be considered applied, methodological and descriptive. During the applied phase, a method proposed by the Ministry of Planning, Budget and Management was used for defining an initial list of indicators, and then two multi-criteria decision methods were employed: analytical hierarchical process (AHP) for the definition of weights for classification criteria; and the TOPSIS technique for final ranking of selected indicators by category of legal requirements. The main results are highlighted as follows: a tool for selection and classification of ME indicators; and a consistent set of indicators proposed for monitoring and evaluating the food allergenic labeling regulation from the perspective of continuous improvement of the whole process; and an effective communication of the regulatory body in the field of food safety.

\section{Keywords}

Metrology; regulation; food safety; food allergenic labeling; monitoring and evaluation; indicators and metrics; multi-criteria decision methods. 


\section{Sumário}

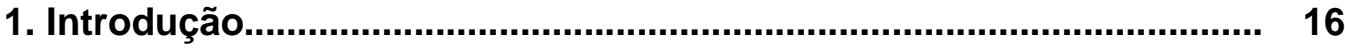

1.1 Definição do problema de pesquisa.................................................... 19

1.2 Objetivos: geral e específicos...................................................... 19

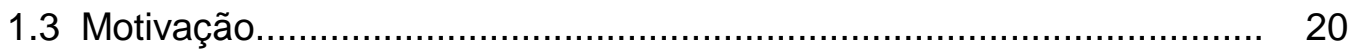

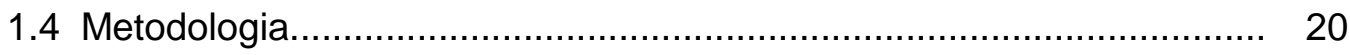

1.4.1 Fase exploratória e descritiva...................................................... 21

1.4.2 Pesquisa aplicada.................................................................... 22

1.4.3 Fase conclusivo-propositiva........................................................... 23

1.5 Estrutura da dissertação..................................................................... 23

2. Gerenciamento da segurança de alimentos e da qualidade na cadeia produtiva de alimentos........................................................ 26

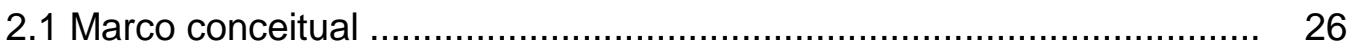

2.2 Normalização e regulamentação aplicáveis.......................................... 28

2.2.1 Codex Alimentarius.......................................................................... 29

2.2.2 Boas Práticas de Fabricação - BPF............................................ 30

2.2.3 Programa de Análise de Perigos e Pontos Críticos de Controle APPCC.

2.2.4 Norma ISO 22000: requisitos para sistemas de gestão da qualidade dos alimentos.

2.3 Segurança de alimentos e o papel da Anvisa no contexto nacional..... 34

2.4 Considerações finais sobre o capítulo............................................. 36

3. Regulamentação sobre rotulagem de alimentos alergênicos no Brasil.

3.1 Antecedentes.

3.2 Proposta de Resolução (RDC) pela Anvisa

3.3 Identificação dos fatores de contexto da regulamentação....................... 42

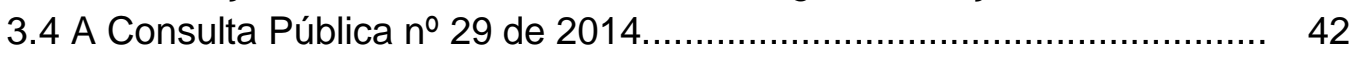

3.5 Considerações finais sobre o capítulo............................................. 43

4. Monitoramento e avaliação como Instrumentos de gestão pública.. 46

4.1 Conceituação e função básica dos indicadores................................... 46

4.2 Taxonomias de indicadores....................................................... 48

4.3 Construção de indicadores.............................................................. 50

4.4 Métodos multicritério de apoio à decisão.......................................... 55

4.4.1 Visão geral e quadro comparativo................................................. 56

4.4.2 Método analítico hierárquico - AHP.......................................... 57

4.4.3 Técnica para avaliar o desempenho de alternativas pela similaridade

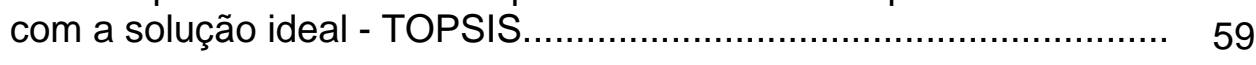

4.5 Considerações finais sobre o capítulo............................................ 60 


\section{Indicadores para monitoramento e avaliação da regulamentação sobre rotulagem de alimentos alergênicos.}

5.1 Construção da matriz de indicadores de MA para a regulamentação em foco

5.1.1 Avaliação do objetivo da regulamentação e resultados esperados.... 64

5.1.2 Identificação das partes interessadas............................................... 66

5.1.3 Definição dos tipos de indicadores................................................ 66

5.1.4 Definição dos critérios de seleção de indicadores............................ 67

5.1.5 Proposição de indicadores iniciais.................................................... 68

5.2 Pré-teste da matriz de avaliação quantitativa de indicadores de MA.... 72

5.3 Aplicação do método AHP para definição dos pesos dos critérios classificatórios.

5.4 Aplicação da técnica TOPSIS para hierarquização final dos indicadores selecionados por categoria de requisitos legais.

5.4.1 Indicadores referentes à categoria "Presença das informações obrigatórias nos rótulos de alimentos alergênicos e

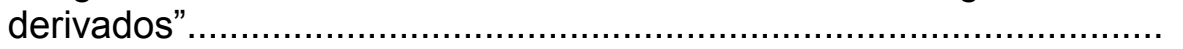

5.4.2 Indicadores referentes à categoria "Presença intencional de alimentos alergênicos e derivados".

5.4.3 Indicadores referentes à categoria "Possibilidade de contaminação cruzada com alimentos alergênicos e seus derivados" ................................................................... 8

5.4.4 Indicadores referentes à categoria "Presença da declaração obrigatória "Contém Glúten" ou "Não Contém Glúten" nos rótulos de alimentos embalados.

5.4.5 Indicadores referentes à categoria "Adequação da informação obrigatória nos rótulos dos alimentos alergênicos e derivados em relação aos parâmetros das regulamentações aplicáveis"....

5.5 Resultado final da hierarquização dos indicadores de MA para a regulamentação em foco.

5.6 Considerações finais sobre o capítulo.

6. Conclusões e recomendações.

Referências bibliográficas

Apêndice 1 - Matriz de avaliação quantitativa de indicadores de MA para a regulamentação sobre rotulagem de alimentos alergênicos e derivados..

Anexo 1 - Descrição do método analítico hierárquico - AHP.

Anexo 2 - Descrição da técnica para avaliar o desempenho de alternativas pela similaridade com a solução ideal - TOPSIS.

Anexo 3 - Proposta de Resolução (RDC) que dispõe sobre rotulagem de alalimentos alergênicos no Brasil.... 


\section{Lista de Figuras}

Figura 1.1 - Desenho da pesquisa, seus componentes e métodos......... 21

Figura 1.2 - Mapa conceitual da pesquisa............................................. 22

Figura 4.1 - Gestão do processo de implementação de um programa governamental............................................................ 48

Figura 4.2 - Ciclo de gestão de programas governamentais.................. 49

Figura 4.3 - Fluxograma da construção de indicadores......................... 50 


\section{Lista de Quadros}

Quadro 3.1 - Categorias de requisitos legais da regulamentação técnica aplicável a alimentos embalados que causam alergias e seus derivados...

Quadro 4.1 - Exemplos de critérios para seleção de indicadores......

Quadro 4.2 - Quadro-resumo dos métodos multicritério de apoio à decisão.

Quadro 5.1 - Bases para a construção da matriz de indicadores de MA da regulamentação sobre rotulagem de alimentos alergênicos e derivados no Brasil.

Quadro 5.2 - Síntese da avaliação dos objetivos da regulamentação e resultados esperados

Quadro 5.3 - Definição dos critérios eliminatórios e classificatórios de indicadores de MA.

Quadro 5.4 - Lista inicial de indicadores de MA para a categoria "Presença das informações obrigatórias nos rótulos de alimentos embalados, incluindo alergênicos".....

Quadro 5.5 - Lista inicial de indicadores de MA para a categoria "Presença intencional de alimentos alergênicos e seus derivados"....

Quadro 5.6 - Lista inicial de indicadores de MA para a categoria "Possibilidade de contaminação cruzada com alimentos alergênicos e seus derivados".

Quadro 5.7 - Lista inicial de indicadores de MA para a categoria 'Presença da declaração obrigatória 'Contém Glúten' ou 'Não Contém Glúten' nos rótulos de alimentos embalados...

Quadro 5.8 - Lista inicial de indicadores de MA para a categoria "Adequação das informações obrigatórias nos rótulos de alimentos embalados alergênicos e derivados".

Quadro 5.9 - Lista geral dos indicadores de MA da regulamentação em foco hierarquizados por categoria de requisitos legais 


\section{Lista de Tabelas}

Tabela 5.1 - Perfil dos participantes da etapa de definição dos critérios classificatórios.

Tabela 5.2 - Comparação pareada dos critérios para classificação de indicadores de MA da regulamentação sobre rotulagem de alimentos alergênicos e derivados

Tabela 5.3 - Pesos dos critérios classificatórios e RC dos julgamentos pelos especialistas.

Tabela 5.4 - Matriz de avaliação quantitativa de indicadores propostos para a categoria "Presença das informações obrigatórias nos rótulos de alimentos embalados, incluindo alergênicos e derivados".

Tabela 5.5 - Soluções ideais PIS e NIS para os critérios classificatórios: categoria "Presença das informações obrigatórias gerais nos rótulos de alimentos embalados alergênicos e derivados".

Tabela 5.6 - Distâncias euclidianas (positivas e negativas) dos indicadores da categoria "Presença das informações obrigatórias nos rótulos de alimentos embalados, incluindo alergênicos e derivados".

Tabela 5.7 - Proximidades relativas de cada indicador em relação à PIS para a categoria "Presença das informações obrigatórias nos rótulos de alimentos embalados, incluindo alergênicos e derivados".

Tabela 5.8 - Hierarquização dos indicadores da categoria "Presença das informações obrigatórias nos rótulos de alimentos embalados, incluindo alergênicos e derivados".

Tabela 5.9 - Matriz de avaliação quantitativa de indicadores propostos para a categoria "Adequação das informações obrigatórias do rótulo em relação aos parâmetros das regulamentações aplicáveis"..............................................

Tabela 5.10 - Soluções ideais PIS e NIS para os critérios classificatórios: categoria "Adequação das informações obrigatórias do rótulo em relação aos parâmetros das regulamentações aplicáveis".....

Tabela 5.11 - Distâncias euclidianas (positivas e negativas) dos indicadores propostos para a categoria "Adequação das informações obrigatórias do rótulo em relação aos parâmetros das regulamentações aplicáveis".

Tabela 5.12 - Proximidades relativas dos indicadores em relação à PIS para a categoria "Adequação das informações obrigatórias do rótulo em relação aos parâmetros das regulamentações aplicáveis". 
Tabela 5.13 - Hierarquização dos indicadores para a categoria "Adequação da informação em relação aos parâmetros das regulamentações aplicáveis"...................................... 85

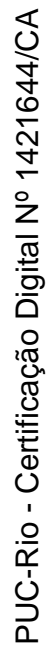




\section{Siglas}

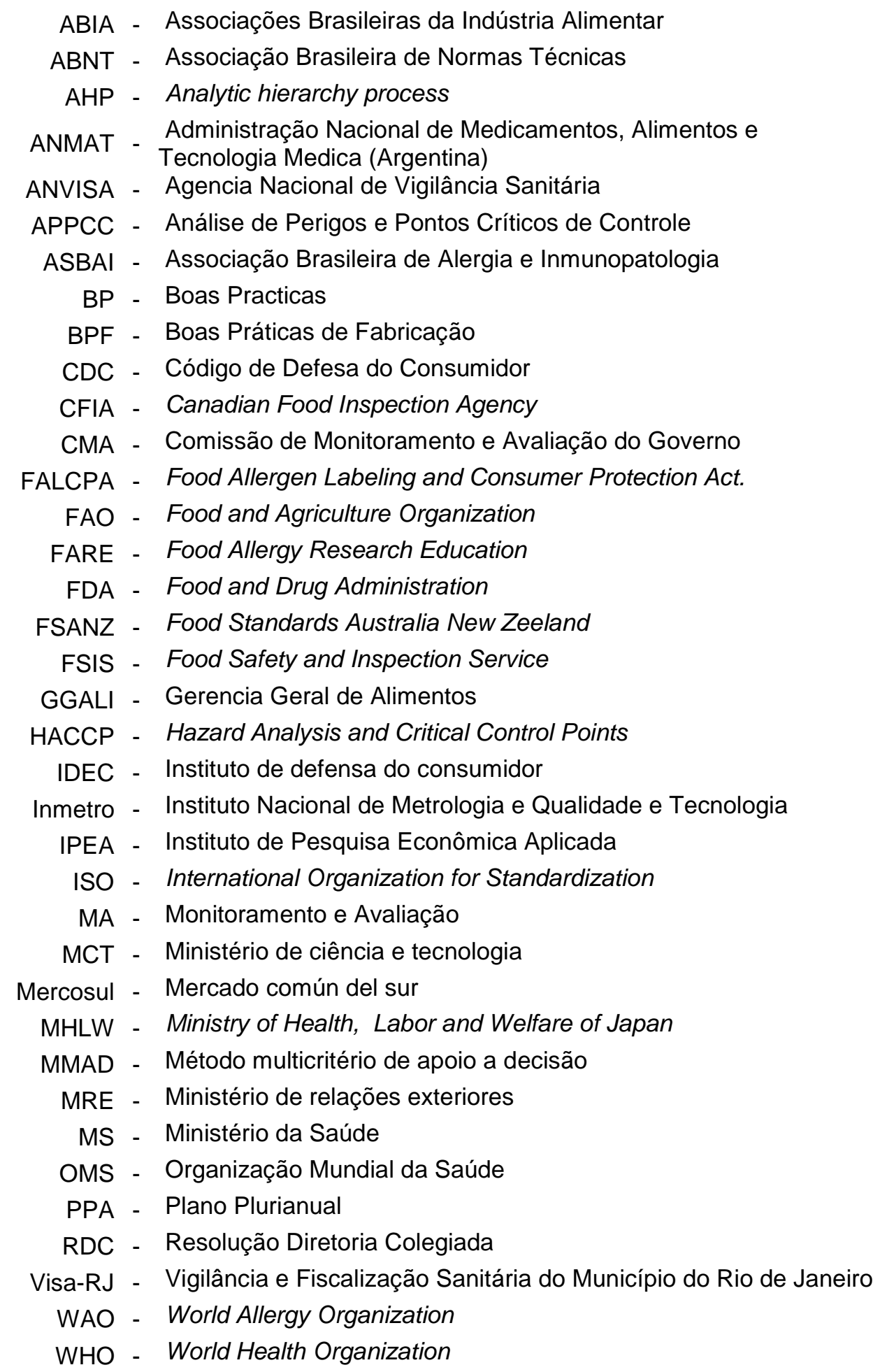




\section{1 \\ Introdução}

O tema controle de alimentos alergênicos tem sido objeto de políticas públicas, regulamentação e normalização em diversos países. Na perspectiva da indústria de alimentos, desde 1990 programas de controle de alergênicos vem sendo desenvolvidos e a inspeção visual da limpeza tornou-se o padrão para a avaliação da eficácia de limpeza dos equipamentos que são compartilhados.

Já os indivíduos que podem desenvolver reações adversas graves a determinados alimentos têm procurado cada vez mais informações sobre os alimentos que consomem. Na maioria dos casos, a única opção razoável para impedir o aparecimento de reações adversas é restringir o consumo de alimentos que causam alergias. Assim, reveste-se de fundamental importância rótulos com informações claras e legíveis sobre a composição dos alimentos, que permitam que os consumidores com alergia identifiquem a presença de componentes causadores de complicações clínicas e assim evitar seu consumo.

Já foram mapeados mais de 170 alimentos que podem causar alergia às pessoas. No entanto, $90 \%$ de casos de alergias alimentares são devido à ingestão de oito ingredientes principais: ovos, leite, peixes, crustáceos, castanhas, amendoim, trigo e soja (Anvisa, 2016).

No Brasil, a regulamentação para rotulagem geral de alimentos embalados encontra-se harmonizado no âmbito do Mercosul e seus requisitos foram internalizados ao ordenamento jurídico nacional, por meio da Resolução RDC ${ }^{\circ}$ 259/2002. Tal regulamento define a lista de informações obrigatórias que devem ser declaradas na rotulagem dos alimentos embalados, com o objetivo maior de prestar informação sobre as características básicas do produto e os aspectos relacionados à segurança do alimento. No entanto, os requisitos para declaração da lista de ingredientes são limitados e diminuem a efetividade das informações fornecidas para quem é alérgico a determinados alimentos (Anvisa, 2013).

A título de ilustração, uma das limitações refere-se à declaração dos nomes dos ingredientes baseada em terminologias técnicas ou científicas que não 
descrevem sua origem. Embora estejam corretos do ponto de vista técnico, alguns termos como albumina e caseína não são termos do cotidiano da maioria dos consumidores, que não conseguem associá-los, respectivamente, a derivados do leite e do ovo.

Outro exemplo de limitação das informações dos rótulos diz respeito às exceções para declaração dos componentes de ingredientes compostos. Alguns ingredientes podem ser declarados por termos genéricos, que não identificam sua origem, como por exemplo, óleos vegetais, amido e especiarias. Também nesses casos de ingredientes compostos, os consumidores com alergias ou intolerâncias alimentares podem não ter acesso a informações essenciais para sua saúde (Anvisa, 2013).

Adicionalmente, os requisitos de legibilidade estabelecidos na legislação têm se mostrado insuficientes para que o consumidor consiga visualizar e ler as informações que estão declaradas nos rótulos. Dentre as principais dificuldades observadas, destacam-se o excesso de informações, a localização na embalagem, o contraste e o tamanho das letras.

Dentre as normas, diretrizes e recomendações que integram o Codex Alimentarius (WHO/FAO, 2016), destaca-se para fins da presente pesquisa a adoção de medidas para garantir a rotulagem clara e precisa de alimentos alergênicos e derivados. Nessa perspectiva, diversos países têm adotado regulamentos técnicos que tornam obrigatória a declaração de componentes alergênicos e têm investido em pesquisas para melhorar os requisitos existentes. No entanto, as principais referências internacionais possuem diferenças na abrangência, lista de alimentos e forma de declaração.

Particularmente, no contexto brasileiro, em função da ausência de estudos nacionais sobre o tema e do aumento de casos de alergias alimentares, a Anvisa apresentou, em 2011, uma proposta no âmbito do Mercosul, que incluía regras específicas para a declaração de ingredientes alergênicos na rotulagem dos alimentos.

Após quatro anos, as discussões sobre a proposta de revisão do regulamento técnico de rotulagem geral avançaram muito pouco. Assim, a Diretoria Colegiada (Dicol) da Anvisa, durante a Reunião Ordinária Interna n. 009/2014, ocorrida em 27/03/2014, aprovou por unanimidade que a Gerência Geral de Alimentos (GGALI) adotasse as providências necessárias para concluir com urgência uma 
proposta de Resolução sobre a rotulagem de alimentos alergênicos para ser submetida à Consulta Pública (Anvisa, 2013).

A GGALI desenvolveu uma revisão bibliográfica e documental sobre a produção científica sobre o tema e a regulamentação internacional, com o objetivo de caracterizar o problema e identificar alternativas regulatórias. Em uma reunião com representantes de diferentes segmentos da sociedade realizada em abril de 2014, a GGALI fez uma apresentação sobre a proposta de regulamentação da rotulagem de alimentos alergênicos e derivados, que abordou diversos aspectos relacionados ao tema, tais como: prevalência de alergia alimentar, severidade e impacto das manifestações clínicas, alimentos envolvidos, limites de segurança de alergênicos, importância da rotulagem para prevenção dos efeitos adversos, problemas relacionados à falta ou baixa qualidade da rotulagem (Anvisa, 2013).

A iniciativa veio ao encontro das demandas da sociedade recebidas pela Agência nos últimos anos. De fato, vinham ocorrendo ações civis públicas pleiteando que a Anvisa regulamentasse a declaração obrigatória de alergênicos e derivados nos rótulos de produtos, como cereais contendo glúten, crustáceos, ovos, peixe, amendoim, soja, leite (incluindo lactose), castanhas, mostarda e gergelim. Ilustra-se com a Campanha Põe no Rótulo, que clamava pela regulamentação sobre a rotulagem de alergênicos, de forma clara, completa e legível.

Todos esses movimentos levaram a Diretoria Colegiada da Anvisa, em reunião realizada em maio de 2014, a aprovar a realização da Consulta Pública ${ }^{\circ}$ 29/2014, que teve como objetivo submeter o assunto a comentários e sugestões do público em geral. O prazo previsto para envio das contribuições foi de 60 dias, a partir do dia 16 de junho de 2014.

A proposta de regulamentação sobre rotulagem de alimentos alergênicos e derivados visava estabelecer os requisitos para a declaração obrigatória na rotulagem de alimentos embalados das fontes reconhecidas por causarem alergias ou intolerâncias alimentares em pessoas sensíveis. Os requisitos aplicavam-se aos alimentos, ingredientes, aditivos alimentares, coadjuvantes de tecnologia e matérias-primas embalados na ausência dos consumidores, inclusive aqueles destinados exclusivamente ao processamento industrial e os destinados aos serviços de alimentação (Anvisa, 2013). 
Complementava a Resolução RDC no 259, de 20 de setembro de 2002, que aprova o regulamento técnico para rotulagem de alimentos embalados, e a Lei ${ }^{\circ}$ 10.674, de 16 de maio de 2003, que estabelece a obrigatoriedade de informação sobre a presença ou ausência de glúten em produtos alimentícios comercializados.

Consciente da importância das ferramentas de monitoramento e avaliação (MA) como instrumentos para medir a eficiência e a eficácia da regulamentação em foco, a Anvisa incluiu a seguinte questão na Consulta Pública nº 29/2014:

"Em sua opinião, quais aspectos da norma proposta necessitam de monitoramento e avaliação após sua implementação? Como isso pode ser feito? Inclua sugestão de indicadores, se achar pertinente" (Anvisa, 2014c).

A questão acima inspirou e norteou o delineamento da pesquisa aqui reportada, na perspectiva de endereçar à Anvisa um conjunto de indicadores e métricas para monitorar e avaliar a regulamentação em foco, após sua implementação.

\section{1 Definição do problema de pesquisa}

Considerando-se a importância do monitoramento e avaliação como instrumento da gestão pública e a necessidade da Anvisa de dispor de indicadores para monitorar e avaliar a regulamentação sobre rotulagem de alimentos alergênicos e derivados, definiu-se a seguinte questão principal a ser respondida ao longo da pesquisa:

"Que indicadores e respectivas métricas devem ser considerados pelo órgão regulador para monitorar e avaliar a regulamentação sobre rotulagem de alimentos alergênicos e derivados no Brasil, após sua implementação?”.

\section{2}

\section{Objetivos: geral e específicos}

Na perspectiva de contribuir para a Anvisa implementar efetivamente uma sistemática de MA da regulamentação sobre rotulagem de alimentos alergênicos e derivados no Brasil, o objetivo geral desta dissertação é propor um conjunto de indicadores e métricas para o monitoramento e avaliação da regulamentação sobre a rotulagem de alimentos alergênicos no Brasil, após sua implementação. Em termos específicos, a dissertação busca: 
- Discutir a importância da regulamentação de rotulagem de alimentos alergênicos e derivados para a segurança de alimentos, particularmente no contexto brasileiro;

- Identificar os aspectos da regulamentação sobre rotulagem de alimentos alergênicos e derivados no Brasil que necessitam de monitoramento e avaliação após sua implementação;

- Elaborar a matriz inicial de indicadores de MA da regulamentação em foco;

- Desenvolver a ferramenta de seleção e classificação de indicadores de MA, com suporte de métodos de apoio à decisão multicritério;

- Propor indicadores e métricas para o monitoramento e avaliação da regulamentação sobre rotulagem de alimentos alergênicos e derivados no Brasil, após sua implementação.

\section{3 \\ Motivação}

No contexto institucional no qual a pesquisa se insere, considera-se que esse esforço propiciará ao órgão regulador, bem como aos diversos atores envolvidos na implementação da regulamentação em foco, o ferramental adequado para o monitoramento e a avaliação de seus resultados.

Espera-se contribuir para o MA do cumprimento do novo regulamento, na perspectiva de minimização da exposição do consumidor alérgico a produtos que possam representar um risco para sua saúde.

Para a Anvisa, os resultados da pesquisa aqui reportados constituem elementos centrais para o desenvolvimento e implantação de uma sistemática de MA, focalizando a implementação da regulamentação abordada.

Finalmente, acredita-se que a ferramenta de seleção e classificação de indicadores desenvolvida poderá ser útil para definição futura de indicadores de monitoramento e avaliação de outras regulamentações voltadas para a garantia de segurança do consumidor.

\section{4 Metodologia}

A Figura 1.1 apresenta a sequência da pesquisa em suas três grandes fases: (i) exploratória e descritiva; (ii) pesquisa aplicada; (iii) conclusivo-propositiva. 
Conforme a taxonomia proposta por (Vergara, 2002;2005) a pesquisa pode ser considerada aplicada, descritiva e metodológica (quanto aos fins).
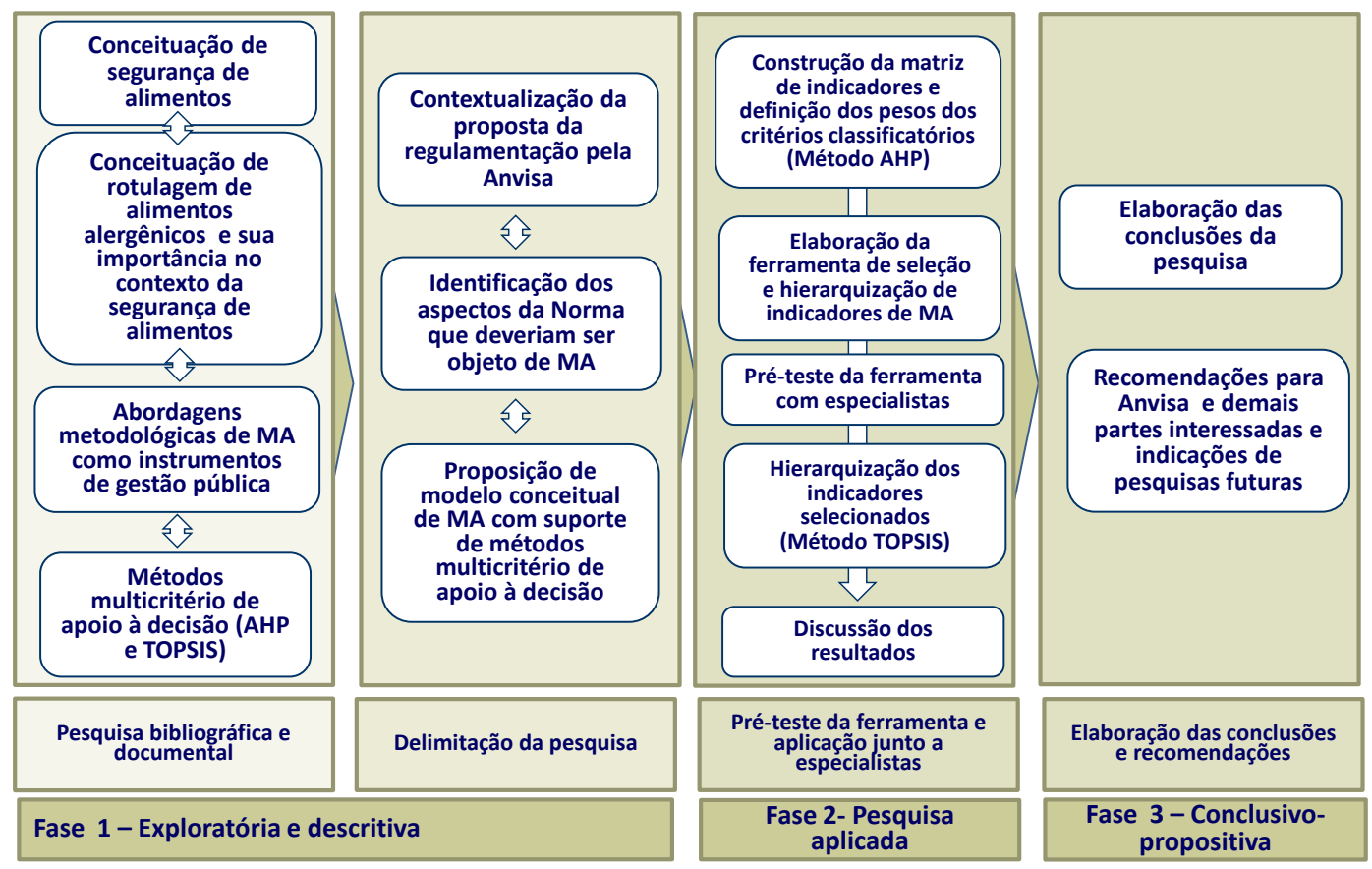

Figura 1.1 - Desenho da pesquisa, seus componentes e métodos Fonte: Elaboração própria.

Quanto aos meios de investigação, a metodologia compreendeu pesquisa bibliográfica e documental sobre os temas centrais da pesquisa, como indicado na fase exploratória e descritiva da Figura 1 . Na fase aplicada, foi usado o método de construção de indicadores proposto pelo Ministério do Planejamento, Orçamento e Gestão, integrado a dois métodos de apoio à decisão: AHP para definição dos pesos dos critérios classificatórios e TOPSIS para hierarquização dos indicadores propostos por categoria de requisitos da regulamentação, a partir dos graus atribuídos pelos especialistas. Destacam-se como resultados a ferramenta de seleção e classificação de indicadores, bem como um conjunto consistente de indicadores de MA, visando à melhoria contínua do processo da regulamentação em foco e a comunicação do desempenho do órgão regulador no campo da segurança de alimentos.

\subsection{1 \\ Fase exploratória e descritiva}

Apresenta-se na Figura 1.2 uma visão geral e esquemática dos resultados desta fase, representada no formato de um mapa conceitual, no qual o tema 
principal e os subtemas específicos contemplados no referencial teórico são interligados para responder a questão principal da pesquisa (definida no item 1.1).

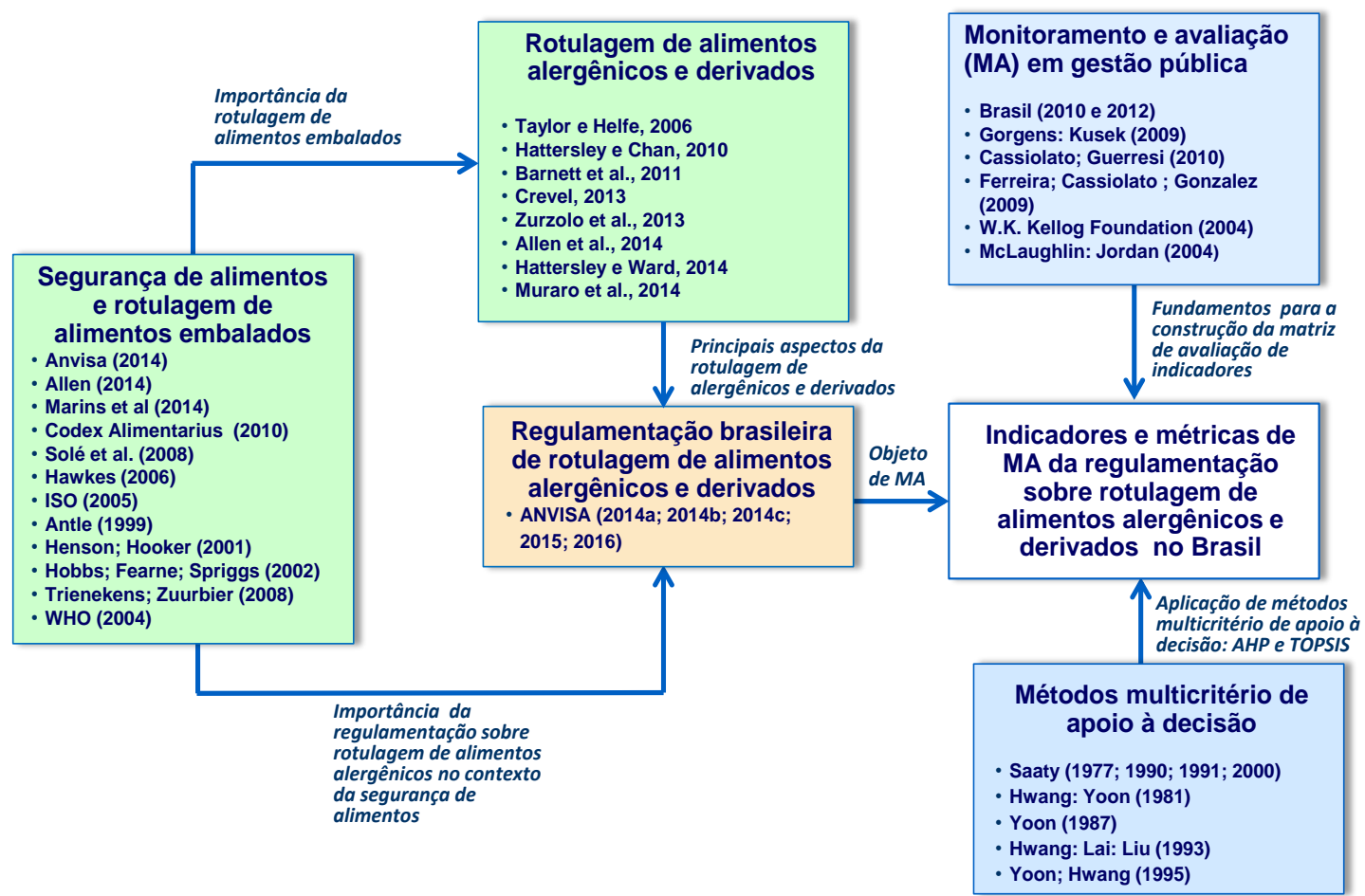

Figura 1.2 - Mapa conceitual da pesquisa

Fonte: Elaboração própria.

A fase 1 - exploratória e descritiva - foi iniciada com pesquisa bibliográfica e documental, com o objetivo de levantar trabalhos conceituais e documentos normativos sobre o tema central da pesquisa - rotulagem de alimentos alergênicos e derivados - integrando abordagens conceituais e metodológicas relacionadas com a questão principal da pesquisa.

Em seguida, buscou-se ainda identificar estudos e documentos sobre segurança de alimentos e rotulagem de alimentos embalados, na perspectiva de contextualizar e discutir a importância da regulamentação em foco para a minimização de riscos à saúde dos consumidores sensíveis a alimentos alergênicos e derivados.

\section{4 .2}

\section{Pesquisa aplicada}

Uma vez selecionados, os resultados da revisão bibliográfica e documental que nortearam a definição dos objetivos da pesquisa, desenvolveu-se a fase da 
pesquisa aplicada propriamente dita, conforme mostrado na Figura 1.1 (Fase 2 Pesquisa Aplicada). As principais etapas desta fase foram: (i) construção da matriz de indicadores de MA e definição dos pesos dos critérios de classificação, utilizando-se o método analítico hierárquico (sigla em inglês, AHP); (ii) elaboração da ferramenta de seleção e hierarquização de indicadores de MA, conforme método proposto pelo Ministério do Planejamento, Orçamento e Gestão (Brasil, 2010; 2012); (iii) realização de pré-teste da ferramenta com mestrandos do Programa de Pós-graduação em Metrologia, visando sua melhoria; (iv) aplicação da ferramenta junto a um grupo de especialistas e mestrandos do referido Programa para comprovar suas funcionalidades; (v) uso da técnica TOPSIS, com o objetivo de hierarquizar os indicadores selecionados, por categoria de requisitos da regulamentação em foco, a partir dos graus atribuídos pelos especialistas; e (vi) apresentação e discussão dos resultados.

\subsection{3}

\section{Fase conclusivo-propositiva}

Nesta fase, formularam-se as conclusões da pesquisa e um conjunto de recomendações à Anvisa e aos diversos atores interessados na aplicação dos indicadores propostos e na efetiva implementação da regulamentação de alimentos alergênicos embalados. Encaminharam-se nesta fase propostas de estudos futuros, como desdobramentos naturais da presente pesquisa.

\section{5}

\section{Estrutura da dissertação}

Esta dissertação encontra-se estruturada em seis capítulos, incluindo esta introdução.

No capítulo 2, apresentam-se o marco conceitual relativo ao gerenciamento da segurança e qualidade na cadeia produtiva de alimentos e os principais referenciais normativos utilizados pelas indústrias alimentícias para atingir um padrão elevado de qualidade e confiabilidade. Incluem-se nesta revisão o Codex Alimentarius; as Boas Práticas de Fabricação (BPF); o Programa de Análise de Perigos e Pontos Críticos de Controle (APPCC); e a Norma ISO 22.000:2005 para a certificação de sistemas de gestão da segurança de alimentos. Finaliza-se o 
capítulo com uma visão geral sobre a atuação da Anvisa em relação à segurança de alimentos, com especial destaque para o controle de alimentos alergênicos.

O capítulo 3 aborda a experiência recente do Brasil relacionada à regulamentação sobre rotulagem de alimentos alergênicos, desde os antecedentes até a proposta de Resolução (RDC) pela Anvisa. Apresentam-se as referências básicas da Resolução nº 26/2015, que estabeleceu as regras para as declarações de rotulagem relativas à: (i) presença intencional de alimentos alergênicos e seus derivados; (ii) possibilidade de contaminação cruzada com alimentos alergênicos ou seus derivados; e (iii) ausência de alimentos alergênicos e seus derivados. Identificam-se os principais fatores de contexto da regulamentação em foco e os aspectos da Norma que deveriam ser objeto de monitoramento e avaliação por parte da Anvisa. Complementa-se essa visão com uma síntese dos resultados da Consulta Pública 29/2014 sobre a proposta de RDC, realizada no início do segundo semestre de 2014.

No capítulo 4, caracterizam-se as atividades de monitoramento e avaliação (MA) como instrumentos da gestão pública, abrangendo conceituação e função básica dos indicadores, além das diversas taxonomias descritas na literatura especializada. Descreve-se o método para construção de indicadores de MA, proposto pelo Ministério do Planejamento, Orçamento e Gestão (Brasil, 2010; 2012), como método de escolha para a fase aplicada da presente pesquisa. $\mathrm{Na}$ sequência, apresenta-se uma visão geral dos principais métodos multicritério de apoio à decisão, com destaque para o método analítico hierárquico (sigla em inglês, AHP) e a técnica TOPSIS, ambos selecionados para a fase seguinte desta pesquisa. O método AHP será aplicado para definir pesos dos critérios para classificar os indicadores de MA propostos para a regulamentação em foco; e a técnica TOPSIS apoiará a hierarquização final dos indicadores propostos para monitorar e avaliar a regulamentação de rotulagem de alimentos alergênicos e derivados no Brasil.

O capítulo 5 tem por objetivo apresentar e discutir os resultados da fase aplicada da pesquisa até a proposição de um conjunto de indicadores para monitoramento e avaliação (MA) da regulamentação sobre rotulagem de alimentos alergênicos e derivados no Brasil, respondendo à questão principal da dissertação. Inicialmente, apresenta-se o processo de construção da matriz quantitativa de indicadores de MA para a regulamentação em foco, que seguiu a 
abordagem metodológica apresentada e discutida no capítulo anterior. Em particular, descreve-se como foram propostos os indicadores iniciais de MA, a partir da análise das categorias de requisitos legais constantes da RDC nº 26/2015 e de outros regulamentos de rotulagem aplicáveis, incluindo-se a realização de um pré-teste da ferramenta. Na sequência, apresentam-se os resultados da aplicação do método analítico hierárquico (sigla em inglês, AHP) para definição dos pesos dos critérios de classificação dos indicadores propostos na etapa anterior e do uso da técnica TOPSIS para hierarquizar, por categoria de requisitos legais, os indicadores de MA da regulamentação em foco.

No capítulo 6, formulam-se as conclusões da pesquisa e endereçam-se propostas para estudos futuros, como desdobramentos naturais e aprofundamento de aspectos relevantes que emergiram da presente pesquisa. 


\section{2 \\ Segurança de alimentos e qualidade na cadeia produtiva de alimentos}

Apresentam-se o marco conceitual relativo ao gerenciamento da segurança de alimentos e da qualidade na cadeia produtiva de alimentos e os principais referenciais normativos utilizados pelas indústrias alimentícias para atingir um padrão elevado de qualidade e confiabilidade. Incluem-se nesta revisão o Codex Alimentarius; as Boas Práticas de Fabricação (BPF); o Programa de Análise de Perigos e Pontos Críticos de Controle (APPCC); e a Norma ISO 22.000:2005 para a certificação de sistemas de gestão da segurança de alimentos. Finaliza-se o capítulo com uma visão geral sobre a atuação da Anvisa em relação à segurança de alimentos, com especial destaque para o controle de alimentos alergênicos.

\section{1 \\ Marco conceitual}

Há cinco décadas, a indústria de alimentos tem evidenciado o aumento da quantidade e a diversidade de produtos oferecidos. Isso reflete consequentemente nas expectativas dos consumidores, bem como em seus hábitos. Observa-se que compradores do passado, embora comprassem frutas, verduras, carnes e peixes em estabelecimentos locais para o preparo das suas próprias refeições, atualmente, estão em busca de conveniência e funcionalidade, adquirindo alimentos de rápido preparo ou escolhendo opções alimentares para entrega ou, ainda fazendo as refeições fora de casa, como, por exemplo, em restaurantes, lanchonetes, ou local dessa categoria.

Por conseguinte, se outrora a distribuição desses produtos alimentícios era limitada e a produção era suficiente para atender às demandas locais, nos dias de hoje, devido à conquista desses alimentos, pode-se constatar novo perigo, o surto de distúrbios diretamente relacionados a esses elementos, o qual tem o potencial de ocorrer em escala nacional, continental ou mesmo global (Dillon e Griffith, 2000). 
Na segunda metade do século XX, devido ao desenvolvimento industrial, houve consequentes mudanças que impactaram hábitos tradicionais da sociedade brasileira. Dentre essas, ressaltam-se novas práticas alimentares e sociais, como, por exemplo, alimentação fora de casa ('comer fora'), considerada um movimento social ou uma necessidade, devido ao fato da presença feminina não ser exclusivamente doméstica, já que essa mulher passa a compor o mercado formal de trabalho. (Mendonça e Anjos, 2004).

É importante enfatizar que a mudança de cultura alimentar deve-se inclusive ao surgimento de fast-foods, os quais proporcionam funcionalidade e mobilidade às refeições, aliadas à mentalidade moderna e aos hábitos de um mundo globalizado. A ampliação dessa modalidade de serviço deveu-se ao crescimento da população interessada por refeições rápidas e de baixo custo. Sob outra perspectiva, o consumo de bebidas, molhos artificiais, sorvetes, itens industrializados, que normalmente acompanham as refeições, também cresceu proporcionalmente. (Bleil, 1998).

Percebe-se, então, que o cuidado com a segurança referente à produção de alimentos industrializados, nos dias atuais, é muito maior em relação passado. Além disso, as consequências do lançamento de um produto aleatório, que pode representar insegurança no mercado, podem tomar dimensões mundiais, por causa do alto grau de globalização da indústria alimentícia. Todas essas transformações forçosamente levaram às indústrias do ramo a se ajustarem ao novo cenário, incorporando, portanto, práticas pertinentes à segurança alimentar.

Após a segunda guerra mundial, que arruinou uma grande parcela do continente europeu, deixando suas terras sem condições de produzir seu próprio alimento, o conceito de segurança ganhou destaque e desde então circunscreve os seguintes aspectos: (i) quantidade; (ii) qualidade; e (iii) regularidade do acesso aos alimentos.

A quantidade é relativa às questões de acesso e disponibilidade, tratados como temas distintos, devido ao fato de o alimento estar disponível, porém não obrigatoriamente acessível a alguma parcela da população (impactos de origem social: atritos internos, monopólio, entre outros).

A qualidade, além de considerar o consumo de forma digna (em ambiente e de maneira higiênica), indica que o alimento disponível não pode apontar nenhum risco de contaminação ou apodrecimento. 
Maluf, Menezes e Marques (2000) salientam que a população deve ter acesso à alimentação de qualidade, seja relacionada à qualidade nutricional dos alimentos consumidos ou à isenção de substâncias danosas à saúde. Essa questão é concernente à qualidade dos alimentos e sua profilaxia, sendo, portanto, dois elementos de suma importância no contexto atual da segurança de alimentos.

Por fim, a regularidade, deve assegurar à população o acesso constante aos alimentos, de modo que a possibilite ao menos fazer três refeições diárias (Belik, 2003).

O tema segurança de alimentos discutido nesta dissertação está alinhado à ideia da qualidade dos alimentos fabricados, além de dizer respeito ao acesso por todos a alimentos isentos e nutritivos, para uma vida ativa e salutar. Quando se fala em segurança, compreende-se um conjunto de regras (desde o transporte das matérias primas até a chegada do produto na mesa do consumidor), que garantem a adequabilidade ao consumo.

Esse conceito está em consonância com os artigos $3^{\circ}$ e $4^{\circ}$ da Lei 11.346. No Brasil, o Código de Defesa do Consumidor (CDC), promulgado através da Lei ${ }^{\circ}$ 8078 de 11 de setembro de 1990, sucedeu da busca pela qualidade de produtos e serviços e da alegação dos direitos dos consumidores, fenômenos de mercado dos últimos 20 anos. O CDC estabelece ser direito básico do consumidor a proteção da vida, saúde e segurança contra riscos oriundos de práticas que podem resultar na distribuição de produtos e serviços danosos à saúde do consumidor. Assim, o fabricante e o produtor são responsabilizados por quaisquer eventuais danos derivados de produtos imperfeitos (Brasil, 1990).

\section{2 \\ Normalização e regulamentação aplicáveis}

Segundo Capiotto e Lourenzani (2010), a competitividade atual entre as empresas do setor de alimentos exige o crescente aperfeiçoamento e a busca pela inovação dos produtos fornecidos. Um dos planos utilizados para atingir o êxito nos negócios tem sido o uso de metodologias e ferramentas de qualidade. Todos os países possuem órgãos reguladores, (agências de proteção à saúde ou entidades mundiais e regionais) que traçam leis, normas e guias, com o propósito de garantir a qualidade do produto fornecido e a efetivação de requisitos básicos, tais como 
higiene e sanitização. As principais ferramentas da qualidade empregadas a fim de alcançar os objetivos associados à qualidade são as Boas Práticas de Fabricação (BPF) e a Análise de Perigos e Pontos Críticos de Controle (APPCC).

O Codex Alimentarius, expressão latina que significa "Código Alimentar" ou "Legislação Alimentar", refere-se a uma compilação de padrões normativos para alimentos, códigos de práticas, além de outras orientações. Os princípios norteadores do Codex direcionam-se à garantia da segurança dos alimentos e, junto com as BPF, formam os pré-requisitos para a implementação do plano APPCC (Bennet e Steed, 1999).

Eventuais divergências de interpretações causadas pelos vários referenciais existentes podem ocorrer. E com o intuito de compatibilizar internacionalmente as diretrizes relacionadas aos sistemas de gestão da qualidade e segurança de alimentos, a International Organization for Standardization (ISO) compôs uma norma internacional unificada, concernente à concepção e ao desenvolvimento de um sistema de gestão da qualidade e de segurança de alimentos, a norma ISO 22.000:2005 (Capiotto e Lourenzani, 2010).

As normas e regulamentos mencionados serão pormenorizados nos subitens a seguir.

\subsection{1}

\section{Codex Alimentarius}

O Programa Codex Alimentarius surgiu em 1962, com a intenção de facilitar o comércio internacional de alimentos, consolidar práticas íntegras de comercialização, salvaguardar o consumidor, programar normas, códigos de prática, linhas de ação e orientações, com a intenção de definir assim padrões de progresso, fabricação e comercialização de produtos alimentícios (FAO/WHO, 2016).

As regras que integram o Codex sobre a aplicação de medidas sanitárias e fitossanitárias para a inocuidade dos alimentos são importantes para o amparo da saúde pública e para um bom desenvolvimento dos mercados internos e internacionais (FAO/WHO, 2016).

A publicação do Codex Alimentarius objetiva orientar e provocar a elaboração de definições e o estabelecimento de requisitos aplicáveis aos 
alimentos, auxiliando a harmonização e, assim, facilitando o comércio internacional (FAO/WHO, 2016).

As diretrizes e requisitos propostos estão relacionados aos aspectos de higiene e propriedades nutricionais dos alimentos, além de o código de práticas e normas de aditivos alimentares; pesticidas e resíduos de medicamentos veterinários; substâncias contaminantes; rotulagem; classificação; métodos de amostragem e análise de riscos.

O Manual de Procedimentos está, na época atual, em sua $23^{a}$ edição. Nessa, descrevem-se os princípios legais e a atividade prática da Comissão e dos seus órgãos subsidiários (FAO/WHO, 2016).

O Comitê Brasileiro do Codex Alimentarius tem a coordenação e secretaria exercidas pelo Instituto Nacional de Metrologia, Qualidade e Tecnologia (Inmetro), composto por instituições particulares e públicas, como, por exemplo, o próprio Inmetro e o Instituto de Defesa do Consumidor (IDEC); os Ministérios das Relações Exteriores (MRE), Saúde (MS), Fazenda (MF), Ciência e Tecnologia (MCT), Justiça (MJ/DPC) e Desenvolvimento, Indústria e Comércio (MDIC/SECEX); as associações brasileiras da Indústria e Alimentação (ABIA) e de Normas Técnicas (ABNT); e das confederações nacionais da Indústria (CNI), da Agricultura (CNA) e do Comércio (CNC) (Mirilli et al., 1996).

\subsection{2}

\section{Boas Práticas de Fabricação - BPF}

Os sistemas de segurança aplicados na indústria de alimentos foram iniciados na década de 50, com a execução das Boas Práticas de Fabricação (BPF), moldadas da indústria farmacêutica. Em 1963, ocorreu um dos primeiros sinais da implementação propriamente dita, quando os Estados Unidos anunciaram um documento intitulado "Good Manufacturing Pratices (GMP)", o qual comunicava suas atividades e recomendações sobre o assunto. As orientações eram recomendações para a prática de processos de controle de qualidade, que foram integradas à estrutura permitida após a sua publicação pela US Food and Drug Administration (US FDA), em 1973 (Deus e Sá, 2011).

Tais rotinas passaram a vigorar no Brasil na década de 70, através das multinacionais farmacêuticas, tais como Bayer, Roche, Hoechst e Johnson \& 
Johnson e, além disto, empresas do setor de alimentos e de cosméticos (Avon e Nestlé, respectivamente) (Brandimarti, 1999).

Controle como água, as contaminações cruzadas, as pragas, a higiene e o comportamento do manipulador, a higienização das superfícies, o fluxo do processo, bem como outros tópicos, todos seguindo normas pré-estabelecidas foram possíveis, após a adoção das BPF pelas empresas no Brasil. (Wurlitzer, 2003).

A Anvisa, no Brasil, define as BPF como:

"um conjunto de medidas que devem ser adotadas pelas indústrias de alimentos a fim de garantir a qualidade sanitária e a conformidade dos produtos alimentícios com os regulamentos técnicos. A legislação sanitária federal regulamenta essas medidas em caráter geral, aplicável a todo o tipo de indústria de alimentos e específico, voltadas às indústrias que processam determinadas categorias de alimentos" (Anvisa, 2015).

Em síntese, as BPF pretendem assegurar a inteireza do alimento produzido como também da saúde do sujeito que irá consumir o alimento, sendo, portanto, regulamentar. Podem, ainda, ser vantajoso do ponto de vista financeiro a partir do momento que são bem implementados, atendendo à diminuição de custos e à melhoria no rendimento e crescimento de mercado (qualidade associada) (Capiotto e Lourenzani, 2010).

\subsection{3}

\section{Programa de Análise de Perigos e Pontos Críticos de Controle - APPCC}

Conforme Bennet e Steed (1999), o Programa de Análise de Perigos e Pontos Críticos de Controle (APPCC), com principal intenção de desenvolver um programa de qualidade que certificasse o suprimento de alimentos confiáveis para os astronautas da NASA, foi utilizado pela primeira vez em meados dos anos 60 , pela empresa Pillsburg Company. Foi durante a Conferência Nacional para Proteção de Alimentos, realizada nos Estados Unidos, que o Programa foi exibido ao público geral pela primeira vez, em 1971.

Trienekens e Zuurbier (2008) explicam que o Programa APPCC tem como uma abordagem sistemática para identificar, avaliar e controlar algumas determinadas etapas do procedimento de produção de alimentos, críticas para a segurança do produto final. No momento presente, os fundamentos desse 
programa constituem o pilar para a maioria dos sistemas de qualidade e segurança dos alimentos.

Athayde (1999), por exemplo, caracteriza o Programa APPCC a partir de uma série de etapas que abarcam todas as execuções da produção dos alimentos (da obtenção da matéria-prima até o consumo final), dando ênfase ao reconhecimento dos potenciais perigos à segurança do alimento, bem como às disposições para o controle das condições que os propiciam, com a finalidade de definição dos pontos sensíveis do processo.

O Programa APPCC foi elaborado para precaver potenciais perigos, quer sejam de ordem microbiológica, física ou química. Resumidamente, trata-se de uma abordagem profícua para certificar a segurança dos alimentos e preservar a saúde pública (Ji-Hyeon e Soung-Hun, 2007).

A metodologia do Programa, além de didática e ordenada, apoia-se em sete ensinamentos básicos. Uma vez obedecidos esses princípios, pode-se controlar os riscos de gerar malefícios à saúde do consumidor final (Felix, Züge e Vicentini, 2003; Trienekens e Zuurbier, 2008). São os ensinamentos:

- Princípio 1: Condução de análise de perigos (químicos, físicos ou biológicos) e procedimentos de prevenção;

- Princípio 2: Determinação dos pontos críticos de controle (PCC);

- Princípio 3: Estabelecimento dos limites críticos;

- Princípio 4: Estabelecimento dos procedimentos de monitoramento do PCC;

- Princípio 5: Estabelecimento de ação corretiva;

- Princípio 6: Estabelecimento de procedimentos de verificação;

- Princípio7: Estabelecimento de procedimentos de registro e documentação.

Capiotto e Lourenzani (2010) ressaltam que, para garantir a eficiência da sistemática do APPCC é primordial que programas de pré-requisitos (BPF) estejam adequadamente implementados.

Trienekens e Zuurbier (2008) mencionam, além das BPF, outros prérequisitos para a implantação do Programa APPCC, tais como (i) princípios de desenho sanitário (de equipamentos); (ii) especificação de todos os ingredientes utilizados na produção (inclusive embalagens); (iii) programação de manutenções; (iv) requisitos de higiene pessoal; (v) procedimentos documentados para assegurar 
a segregação e uso apropriado de produtos químicos; e (vi) procedimentos de rastreabilidade e de recolhimento devidamente implementados.

Capiotto e Lourenzani (2010) salientam que o APPCC é integralmente mutável, sendo, portanto, passível de alteração e adequação às distintas necessidades de gestão de cada indústria e de cada processo, em conformidade com as suas peculiaridades, além de aceitável a todas as fases da produção, transformação e distribuição de alimentos, apesar da dimensão da organização.

Os autores concluem, então, que, nos dias atuais, as BPF e o Programa APPCC são instrumentos extensamente aconselhados pelos órgãos de vigilância brasileiros, como a Anvisa e o Ministério da Agricultura, Pecuária e Abastecimento (Mapa), sendo seu uso proposto em toda a extensão da cadeia produtiva de alimentos.

\subsection{4}

\section{Norma ISO 22000: requisitos para sistemas de gestão da qualidade dos alimentos}

A família ISO 22000 compõe-se de um conjunto de regras ISSO, direcionadas para a gestão da segurança alimentar. Como as implicações da produção de alimentos incertos, ou não, de acordo com as premissas lícitas podem ser deveras graves, essas normas contribuem para a identificação e para o controle dos riscos de segurança alimentar, considerando a inevitabilidade da garantia de segurança dos alimentos, já que os produtos alimentícios atravessam fronteiras facilmente e podem ser ingeridos em qualquer lugar do planeta (ISO, 2005).

A norma ISO 22000 - 'Sistemas de Gestão da Segurança de Alimentos: Requisitos para qualquer organização da cadeia produtiva de alimentos' foi exposta no dia $1^{\circ}$ de setembro de 2005 , com o intuito de organizar e controlar os riscos e perigos na segurança dos alimentos e buscar incessantemente produtos finais seguros capazes de atender às expectativas dos consumidores finais, assim como aos requisitos regulamentares. Independente do tamanho, da particularidade ou a colocação da cadeia produtivas de alimentos, ela pode ser utilizada por qualquer organização. (Capiotto e Lourenzani, 2010).

De modo geral, a principal intenção da norma ISO 22000 é o equilíbrio, em nível global, dos quesitos da gestão da segurança alimentar. Está direcionada para empresas que busquem um sistema de gerenciamento da segurança de alimentos 
focado, coerente e integrado ao ser comparado ao que é exigido pela legislação, respeitando as condições legítimas aplicáveis (Baptista, 2007).

Sobrea as BPF e os padrões estabelecidos no Codex Alimentarius, a ISO publicou em 2005 a primeira versão da norma ISO 22.000:2005 (ABNT, 2006), como resultado de um processo de harmonização mundial, que levou em consideração normas de diversos países sobre o assunto. Atualmente, a versão de 2005 está sendo revisada, com lançamento da nova versão previsto para meados de 2016 (ISO, 2015).

A tradução da norma ISO 22000 para a língua portuguesa foi realizada em 2006 por representantes de toda a cadeia produtiva de alimentos. A versão brasileira foi denominada ABNT NBR ISO 22.000:2006 - Sistemas de Gestão da Segurança de Alimentos - Requisitos para qualquer organização na cadeia produtiva de alimentos.

Os requisitos da norma ISO 22000 combinam os elementos principais e base, reconhecidos na garantia da segurança, ao longo de toda a cadeia de produção. São eles:

- Comunicação interativa: respalda-se na comunicação entre as partes inteiras da cadeia, sendo elementar para a garantia do controle de todas as ameaças relevantes. Essa comunicação indica basear-se em análises sistemáticas dos riscos e propõe que seja planejada e mantida;

- Gestão de sistema: ocorre quando o sistema de segurança de alimentos é mais eficiente ao ser incorporado às atividades administrativas globais da organização;

- Adoção de um programa de pré-requisitos: referem-se às boas práticas de fabricação;

- Aplicação dos princípios APPCC: menciona os pré-requisitos para a implementação da norma (ABNT, 2006).

Dentre as diversas prerrogativas da implementação da norma apontadas pela ABNT (2006), destacam-se:

- Os requisitos para um sistema de gestão integral para a produção de alimentos resguardados, que estão para além dos requisitos do Programa APPCC;

- Ser reconhecido e praticado internacionalmente;

- A auditabilidade de modo que as organizações sejam livres para escolherem as estratégias e abordagens necessárias para suporte dos requisitos da norma; 
- A possibilidade de harmonização de todas as normas de segurança de alimentos, tornando-se uma componente chave para as empresas do setor;

- A aplicabilidade a qualquer organização introduzida na cadeia produtiva de alimentos;

- A promoção de uma comunicação organizada e direta entre os atores da cadeia;

- A realização de um controle efetivo e dinâmico dos potenciais riscos à segurança dos alimentos;

- A identificação de todas as medidas de domínio para a análise de perigos;

- O gerenciamento sistemático dos programas de pré-requisitos;

- Maior confiabilidade das organizações que elegem essa norma, dilatando a confiança dos consumidores e ampliando o potencial de conquista de novos mercados, cada vez mais exigentes;

- A definição de um sistema de gerenciamento direcionado para a segurança dos alimentos fornecidos por meio de uma estrutura de trabalho objetiva, elucidativa e maleável para as necessidades e expectativas de cada tipo de negócio;

- O fornecimento de uma ferramenta para obtenção de um melhor desempenho da segurança de produto.

\section{3}

\section{Segurança de alimentos e o papel da Anvisa no contexto nacional}

A criação e operação das agências reguladoras integra as práticas do governo federal em conformidade com as exigências sociais e políticas do país. A Agência Nacional de Vigilância Sanitária (Anvisa) foi criada pela Lei no 9.782, de 26 de janeiro de 1999. Trata-se de um órgão independente que elege seus dirigentes por um período de mandato, além de oferecer autonomia financeira.

A Anvisa está vinculada ao Ministério da Saúde e tem como alvo institucional "promover a proteção da saúde da população por intermédio do controle sanitário da produção e da comercialização de produtos e serviços submetidos à vigilância sanitária, inclusive dos ambientes, dos processos, dos insumos e das tecnologias a eles relacionados".

Os produtos e serviços em questão são medicamentos, alimentos, cosméticos, saneantes, oriundos do tabaco, gêneros médicos, sangue e hemoderivados e serviços de saúde em geral. É importante destacar que ainda há 
atuação em portos, aeroportos e fronteiras, no que tange a assuntos internacionais associados à vigilância sanitária (Brasil, 1999).

Mais especificamente na área de alimentos, a Anvisa é a responsável por:

- Aprovar previamente novos produtos alimentícios a serem fabricados ou comercializados no país;

- Controlar novas tecnologias que podem influenciar a saúde da população, de modo a assegurar o tripé: qualidade-eficácia-segurança;

- Associar ao Ministério das Relações Exteriores e controlar os portos, aeroportos e fronteiras;

- Monitorar e fiscalizar os ambientes, processos e insumos ligados aos alimentos;

- Manter e aperfeiçoar as diretrizes técnicas e normativas de todos os produtos conectados à saúde (PRS), como, por exemplo, normas técnicas e padrões de produção, manual de boas práticas de produção;

- Licenciar os estabelecimentos, registrar os alimentos, elaborar normas oficiais (RDC, Portarias), entre outras (Anvisa, 2014).

É também a Anvisa que regulamenta as Boas Práticas de Fabricação aplicáveis à indústria de alimentos, por intermédio dos seguintes documentos:

- Portaria no 1428, de 26 de novembro de 1993: aprova o "Regulamento Técnico para Inspeção Sanitária de Alimentos", as "Diretrizes para o Estabelecimento de Boas Práticas de Produção e de Prestação de Serviços na Área de Alimentos" (Brasil, 1993);

- Portaria no 326, de 30 de julho de 1997: aprova o Regulamento Técnico sobre "Condições Higiênico-Sanitárias e de Boas Práticas de Fabricação para Estabelecimentos Produtores/Industrializadores de Alimentos" (Brasil, 1997);

- Resolução RDC no 275, de 21 de outubro de 2002, que dispõe sobre o Regulamento Técnico de Procedimentos Operacionais Padronizados aplicados aos Estabelecimentos Produtores/Industrializadores de Alimentos e a Lista de Verificação das Boas Práticas de Fabricação (Brasil, 2002).

Em particular, referente à rotulagem de alimentos alergênicos - cerne desta pesquisa - a Resolução de Diretoria Colegiada (RDC) $n^{\circ} 26$, de 2 de julho de 2015, dispõe sobre os requisitos para rotulagem obrigatória dos alimentos fundamentais, causadores de alergias alimentares. O objetivo desta RDC é assegurar que as informações corretas cheguem até o consumidor final, além de 
alertar sobre a existência dos principais alimentos alergênicos e seus derivados, determinando regras para as declarações de rotulagem relativas à: (i) presença intencional de alimentos alergênicos e seus derivados; (ii) possibilidade de contaminação cruzada com alimentos alergênicos ou seus derivados; e (iii) ausência de alimentos alergênicos e seus derivados.

Recentemente, a Agência publicou o Guia n ${ }^{\circ}$ 5/2016 sobre Programa de Controle de Alergênicos, em vigor desde o dia 01 de abril de 2016. Esse Guia objetiva oferecer orientações às indústrias de alimentos e ao Sistema Nacional de Vigilância Sanitária (SNVS) sobre os aspectos mais importantes a serem tratados em um Programa de Controle de Alergênicos (PCAL), uma condição para a aplicação da Resolução de Diretoria Colegiada (RDC) $n^{\circ} 26$, de 2 de julho de 2015. No capítulo 3, esses aspectos serão retomados, como base para a proposição de indicadores e métricas de monitoramento e avaliação da regulamentação em foco.

\section{4 \\ Considerações finais sobre o capítulo}

O número crescente de controles associados à segurança de alimentos e a exigências dos consumidores reforçam a preocupação das empresas ao estabelecerem metodologias para uma efetiva gestão das questões e aspectos relacionados a essa temática. $\mathrm{O}$ advento das redes sociais e a grande oferta de produtos alimentícios são fatores que colaboram para a urgência na integridade desses produtos. Unida à gestão da qualidade em toda a cadeia produtiva de alimentos, a segurança do alimento deve ser garantida da mesma forma.

A globalização está presente na distribuição de alimentos e um produto potencialmente perigoso à saúde dos consumidores pode causar um impacto generalizado à saúde pública.

Neste capítulo, buscou-se apresentar os fundamentos e opiniões de especialistas e organismos internacionais, tais como a FAO e a WHO, acerca da segurança de alimentos e qualidade na cadeia produtiva de alimentos. Destacaram-se os principais referenciais normativos internacionais adotados pelas indústrias alimentícias para alcançar um padrão elevado de qualidade e confiabilidade, como as Boas Práticas de Fabricação (BPF), o Programa de 
Análise de Perigos e Pontos Críticos de Controle (APPCC) e a norma ISO 22.000:2005.

A segurança está profundamente associada à possível presença de perigos, no momento do consumo do alimento e à entrada dos mesmos na cadeia de produção pode dar-se em qualquer etapa. Por conseguinte, é primordial que haja um controle apropriado no decorrer de toda a cadeia, visando garantir a segurança do alimento, além de combinar esforços de todas as partes que integram o processo. Logo, é neste contexto que, a rastreabilidade se aponta como um instrumento importante para a identificação da origem das matérias primas e dos cenários em que se produzem os alimentos. Ademais, a rastreabilidade contribui para a identificação de lotes contaminados, facilitando sua retirada do mercado; e a demarcação de respectivas responsabilidades.

O objetivo da regulamentação voltada para a segurança de alimentos está pautado na adequação das empresas para o fornecimento de produtos de elevada qualidade e totalmente seguros para os consumidores. As metodologias e ferramentas da qualidade aqui abordadas têm sido amplamente usadas pelas organizações para, simultaneamente, atenderem a requisitos legais e garantirem a segurança e a satisfação do consumidor. Como abordado, as ferramentas essenciais são as Boas Práticas de Fabricação e o Programa APPCC, que constituem pré-requisitos para a adoção da norma ISO 22000:2005. Percebe-se que os temas estão concatenados e cooperam para a mesma finalidade: a fabricação e o fornecimento de alimentos seguros para os consumidores.

Finalmente, ressaltou-se o papel da Anvisa no contexto da segurança de alimentos no Brasil, com destaque para a atenção especial que essa Agência tem dado ao controle de alergênicos e à definição dos requisitos para rotulagem obrigatória dos principais alimentos que causam alergias alimentares. 


\section{3 \\ Regulamentação sobre rotulagem de alimentos alergênicos no Brasil}

Aborda-se a experiência recente do Brasil relacionada à regulamentação sobre rotulagem de alimentos alergênicos, desde os antecedentes até a proposta de Resolução (RDC) pela Anvisa. Apresentam-se as referências básicas da Resolução n $n^{\circ}$ 26/2015, que estabeleceu as regras para as declarações de rotulagem relativas à: (i) presença intencional de alimentos alergênicos e seus derivados; (ii) possibilidade de contaminação cruzada com alimentos alergênicos ou seus derivados; e (iii) ausência de alimentos alergênicos e seus derivados. Identificamse os principais fatores de contexto da regulamentação em foco e os aspectos da Norma que deveriam ser objeto de monitoramento e avaliação por parte da Anvisa. Complementa-se essa visão com uma síntese dos resultados da Consulta Pública 29/2014 sobre a proposta de RDC, realizada no início do segundo semestre de 2014.

\section{1}

\section{Antecedentes}

Diversas limitações na regulamentação da rotulagem de alimentos embalados prejudicavam a identificação da presença de constituintes alergênicos, a saber: (i) terminologia técnica ou científica empregada na lista de ingredientes dificulta o entendimento do consumidor; (ii) muitos ingredientes são declarados por meio de termos genéricos, que não identificam sua origem; (iii) os componentes de ingredientes compostos e os coadjuvantes de tecnologia, em muitos casos, não são declarados, podendo ocultar a presença de alergênicos; (iv) a legibilidade da rotulagem tem se mostrado insuficiente para garantir que o consumidor consiga visualizar e ler as informações declaradas (Anvisa, 2015).

Particularmente, em função da ausência de estudos nacionais sobre o tema e do aumento de casos de alergias alimentares, a Anvisa apresentou, em 2011, uma proposta no âmbito do Mercosul, que incluía regras específicas para a declaração de ingredientes alergênicos na rotulagem dos alimentos. 
Após quatro anos, as discussões sobre a proposta de revisão do regulamento técnico de rotulagem geral avançaram muito pouco. Assim, a Diretoria Colegiada (Dicol) da Anvisa, durante a Reunião Ordinária Interna n. 009/2014, ocorrida em 27/03/2014, aprovou por unanimidade que a Gerência Geral de Alimentos (GGALI) adotasse as providências necessárias para concluir com urgência uma proposta de Resolução sobre a rotulagem de alimentos alergênicos para ser submetida à Consulta Pública (Anvisa, 2013).

Naquele ano, a GGALI realizou uma revisão bibliográfica sobre o tema (Taylor e Helfe, 2006; Hattersley e Chan, 2010; Barnett et al., 2011; Crevel, 2013; Zurzolo et al., 2013; Allen et al., 2014; Hattersley e Ward, 2014; Muraro et al., 2014) e analisou a regulamentação de outros países (EUA, Canadá, Japão, Comunidade Europeia, Austrália e Nova Zelândia) sobre rotulagem de alimentos alergênicos, com o objetivo de caracterizar o problema e identificar alternativas regulatórias

Em uma reunião com representantes de diferentes segmentos da sociedade realizada em abril de 2014, a GGALI fez uma apresentação sobre a proposta de regulamentação da rotulagem de alimentos alergênicos e derivados, abordando aspectos críticos como prevalência de alergia alimentar, severidade e impacto das manifestações clínicas, alimentos envolvidos, limites de segurança de alergênicos, importância da rotulagem para prevenção dos efeitos adversos e problemas relacionados à falta ou baixa qualidade da rotulagem.

Essa iniciativa veio ao encontro das demandas da sociedade recebidas pela Agência nos últimos anos. De fato, foram inúmeras ações civis públicas pleiteando que a Anvisa regulamentasse a declaração obrigatória de alergênicos e derivados nos rótulos de produtos, como cereais contendo glúten, crustáceos, ovos, peixe, amendoim, soja, leite (incluindo lactose), castanhas, mostarda e gergelim. Ilustra-se com a Campanha Põe no Rótulo, que clamava pela regulamentação sobre a rotulagem de alergênicos, de forma clara, completa e legível.

Todos esses movimentos levaram a Diretoria Colegiada da Anvisa, em reunião realizada em maio de 2014, a aprovar a realização da Consulta Pública ${ }^{\circ}$ 29/2014, que teve como objetivo submeter o assunto a comentários e sugestões do público em geral. O prazo previsto para envio das contribuições foi de 60 dias, a partir do dia 16 de junho de 2014. 
A proposta de regulamentação sobre rotulagem de alimentos alergênicos e derivados visava estabelecer os requisitos para a declaração obrigatória na rotulagem de alimentos embalados das fontes reconhecidas por causarem alergias ou intolerâncias alimentares em pessoas sensíveis. Os requisitos aplicavam-se aos alimentos, ingredientes, aditivos alimentares, coadjuvantes de tecnologia e matérias-primas embalados na ausência dos consumidores, inclusive aqueles destinados exclusivamente ao processamento industrial e os destinados aos serviços de alimentação (Anvisa, 2013).

Complementava a Resolução RDC no 259, de 20 de setembro de 2002, que aprova o regulamento técnico para rotulagem de alimentos embalados, e a Lei ${ }^{\circ}$ 10.674, de 16 de maio de 2003, que estabelece a obrigatoriedade de informação sobre a presença ou ausência de glúten em produtos alimentícios comercializados.

No Relatório de Consolidação da Consulta Pública no 29/2014 e da Audiência Pública $n^{\circ}$ 1/2015, a Anvisa reforçou “a necessidade de uma intervenção regulatória para garantir que os consumidores tenham acesso a informações de rotulagem claras, simples e precisas sobre a presença dos principais alimentos que causam alergias alimentares” (Anvisa, 2015).

\section{2 \\ Proposta de Resolução (RDC) pela Anvisa}

A Anvisa elaborou a RDC $n^{\circ} 26 / 2015$ com o objetivo de garantir aos consumidores o acesso a informações corretas, compreensíveis e visíveis sobre a presença dos principais alimentos alergênicos e seus derivados, estabelecendo regras para as declarações de rotulagem relativas à: (i) presença intencional de alimentos alergênicos e seus derivados; (ii) possibilidade de contaminação cruzada com alimentos alergênicos ou seus derivados; e (iii) ausência de alimentos alergênicos e seus derivados.

Esse regulamento técnico abrange todos os fornecedores de alimentos, ingredientes, aditivos alimentares e coadjuvantes de tecnologia, que sejam embalados na ausência dos consumidores, inclusive aqueles destinados exclusivamente para fins industriais. Essa ampla abrangência foi definida em função da complexidade atual da cadeia produtiva de alimentos e da responsabilidade de cada ator no controle de ingredientes potencialmente 
alergênicos e na transmissão de informações adequadas sobre a composição de seus produtos.

Estabeleceu-se uma relação com os principais alimentos alergênicos e derivados pela sua relevância para a saúde pública, considerando-se os dados científicos e as referências legais existentes. Assim, a RDC n 26/2015 engloba 18 tipos de alimentos alergênicos, com destaque para ovos, leite, peixes, crustáceos, castanhas, amendoim, trigo e soja.

Os fabricantes e importadores de alimentos constantes dessa relação deverão seguir obrigatoriamente a padronização da Norma RDC n 26/2015 para as advertências inseridas na rotulagem de alimentos alergênicos e seus derivados por eles ofertados no mercado brasileiro. Conforme essa regulamentação, as advertências contidas nos rótulos devem iniciar sempre com o termo "alérgicos" seguidos das respectivas declarações de conteúdo e do nome comum dado ao produto alergênico. Além disso, os fabricantes e importadores deverão seguir ainda os requisitos de legibilidade da localização das exigências e da advertência nos rótulos.

Há requisitos específicos da Norma para os alimentos alergênicos com embalagem pequena. Nesse caso, fica estabelecido que a altura mínima dos caracteres utilizados nas advertências é de $1 \mathrm{~mm}$. Já para os produtos sem lista de ingredientes, que são aqueles compostos por um único elemento, as advertências não precisam estar imediatamente após a lista. Os fabricantes e importadores não devem colocá-las em local encoberto, de difícil visualização ou que possa ser removidas pela abertura do lacre.

A RDC $n^{\circ}$ 26/2015 prevê um prazo de 12 meses para as empresas promoverem as adequações necessárias na rotulagem de alimentos alergênicos. $\mathrm{O}$ descumprimento representa infração sanitária, conforme a Lei ${ }^{\circ}$ 6.437, de 20 de agosto de 1977.

Como resultado, a Anvisa espera que os produtos tenham informações claras e específicas em seus rótulos sobre alimentos alergênicos e seus derivados. Desse modo, sempre que necessário o consumidor poderá identificar os alimentos alergênicos contidos em determinado alimento embalado e fazer a melhor escolha na hora da compra, sem riscos para sua saúde.

No Anexo 3, apresenta-se o documento objeto da Consulta Pública na íntegra. 


\section{3 Identificação dos fatores de contexto da regulamentação}

A identificação dos fatores relevantes de contexto contribui para uma reflexão das possíveis influências, tanto positivas quanto negativas, relacionadas às ações de implementação da regulamentação sobre rotulagem de alimentos alergênicos.

Dentre os aspectos favoráveis, ressaltam-se: (i) cenário regulatório internacional e alternativas regulatórias existentes em diversos países sobre rotulagem de alimentos alergênicos e derivados; (ii) conscientização e apoio por parte da Anvisa e órgãos de vigilância locais; (iii) oportunidade de monitoramento e avaliação efetivo da implementação da regulamentação sobre rotulagem de alimentos alergênicos e seus derivados no país; (iii) respaldo da sociedade, especialmente das associações e movimentos criados para alertar o consumidor em relação ao risco à saúde devido à ingestão de alimentos alergênicos e seus derivados, como por exemplo, o movimento "Põe no Rótulo" e a Associação Brasileira de Alergia e Imunopatologia.

Como fatores desfavoráveis ou limitantes, citam-se: (i) início da curva de aprendizado, por se tratar de regulamentação recente; (ii) necessidade de um período de adaptação das empresas para cumprimento da regulamentação; (iii) inexistência de estudos que avaliem a real prevalência de alergia alimentar no Brasil (ex. questões metodologias, variabilidade populacional, alimentos envolvidos); e (iv) necessidade de adoção de outras ações para garantir o direito à alimentação adequada dos indivíduos afetados.

\section{4}

\section{A Consulta Pública no 29 de 2014}

A proposta da regulamentação sobre rotulagem de alimentos alergênicos no Brasil foi submetida à Consulta Pública ${ }^{\circ} 29$ de 2014, publicada no Diário Oficial da União no dia 05 de junho de 2014, para comentários e sugestões do público em geral.

Ficou estabelecido um prazo de 60 dias para o envio das opiniões sobre o texto da proposta, contribuições essas consideradas públicas, por meio eletrônico (formulário disponibilizado no site da Anvisa) ou por meio físico (cartas encaminhadas à Agência) (Anvisa, 2014a). 
Foi adotado o uso do formulário eletrônico (FormSUS) do Departamento de Informática do Sistema Único de Saúde (DataSUS) para facilitar e agilizar a compilação, análise das contribuições da consulta pública e resposta da Agência aos respondentes, assim como possibilitar a visualização em tempo real das sugestões e críticas recebidas.

A Consulta Pública contemplou os artigos do texto inicial da proposta de regulamentação, individualmente, para que sugestões e críticas fossem feitas item a item da Norma. Solicitava os dados pessoais do respondente, como nome, declaração de cor, localidade e segmento que representava.

Finalmente, algumas questões sobre a proposta em si foram abordadas, como a opinião do respondente sobre a norma em discussão, alternativa à proposta (caso o respondente em questão discorde da necessidade da regulamentação), a avaliação dos impactos da proposta sobre a rotina e as atividades do respondente, a intensidade dos impactos identificados e, ao final, a questão que inspirou a presente pesquisa:

"Em sua opinião, quais aspectos da norma proposta necessitam de monitoramento e avaliação após sua implementação? Como isso pode ser feito (inclua sugestão de indicadores, se achar pertinente".

A Anvisa consolidou as informações obtidas e disponibilizou aos interessados uma planilha completa, reunindo todas as contribuições recebidas. Foram 5.475 contribuições, oriundas de 3.531 participantes no total, sendo 96,5\% pessoas físicas e 3\% representantes de instituições. Além disso, em 2015, foi realizada uma Audiência Pública no 1/2015, que contou com 119 participantes e 1.788 acessos virtuais (Anvisa, 2014d).

Especificamente em relação à questão objeto da presente dissertação, foram preenchidos 748, representando 21,18\% do total de respondentes (Anvisa, 2014c).

\section{5}

\section{Considerações finais sobre o capítulo}

Buscou-se neste capítulo alcançar um dos objetivos específicos da pesquisa, qual seja: “identificar os aspectos da regulamentação sobre rotulagem de alimentos alergênicos e derivados que necessitam de monitoramento e avaliação, após sua implementação", conforme a questão posta na Consulta Pública n 29 de 2014. 
Para fins da presente pesquisa, consideram-se como aspectos da Norma que necessitam de monitoramento e avaliação por parte da Anvisa cinco categorias de requisitos legais da regulamentação sobre rotulagem de alimentos alergênicos e outras complementares aplicáveis, como a Resolução RDC n² 259, de 20 de setembro de 2002 e a Lei $n^{\circ} 10.674$, de 16 de maio de 2003.

O Quadro 3.1 apresenta as cinco categorias de requisitos legais da regulamentação técnica aplicáveis a alimentos embalados que causam alergias e seus derivados.

Quadro 3.1 - Categorias de requisitos legais da regulamentação técnica aplicável a alimentos embalados que causam alergias e seus derivados

\begin{tabular}{|c|c|c|}
\hline Categoria de requisitos legais & Descrição & Regulamento Técnico \\
\hline $\begin{array}{l}\text { Presença das informações } \\
\text { obrigatórias nos rótulos de } \\
\text { alimentos embalados, incluindo } \\
\text { alergênicos e derivados }\end{array}$ & $\begin{array}{l}\text { Informações referentes a: (i) } \\
\text { denominação de venda do alimento; (ii) } \\
\text { lista de ingredientes; (iii) conteúdos } \\
\text { líquidos; (iv) identificação da origem; (v) } \\
\text { nome ou razão social e endereço do } \\
\text { importador, nos casos de alimentos } \\
\text { importados; (vi) identificação do lote; } \\
\text { (vii) prazo de validade; (viii) instruções } \\
\text { sobre o preparo e uso do alimento. }\end{array}$ & $\begin{array}{l}\text { Resolução RDC no 259, } \\
\text { de } 20 \text { de setembro de } \\
2002 \text {. }\end{array}$ \\
\hline
\end{tabular}

\begin{tabular}{|c|c|c|}
\hline \multirow{6}{*}{$\begin{array}{l}\text { Presença intencional de } \\
\text { alimentos alergênicos e seus } \\
\text { derivados, conforme Resolução } \\
\text { RDC no } 26 \text {, de } 02 \text { de julho de } \\
2015 \text {. }\end{array}$} & $\begin{array}{l}\text { Declaração "Alérgicos: Contém [nomes } \\
\text { comuns dos alimentos que causam } \\
\text { alergias alimentares]" }\end{array}$ & \multirow[t]{2}{*}{$\begin{array}{l}\text { Resolução RDC no 26, } \\
\text { de } 02 \text { de julho de } 2015 .\end{array}$} \\
\hline & $\begin{array}{l}\text { Nomes comuns referem-se aos } \\
\text { alimentos constantes do Anexo da RDC } \\
\text { no 26/2015 (18 alimentos). }\end{array}$ & \\
\hline & $\begin{array}{l}\text { Declaração "Alérgicos: Contém derivados } \\
\text { de [nomes comuns dos alimentos que } \\
\text { causam alergias alimentares]" }\end{array}$ & \multirow[t]{2}{*}{$\begin{array}{l}\text { Resolução RDC no 26, } \\
\text { de } 02 \text { de julho de } 2015 \text {. }\end{array}$} \\
\hline & $\begin{array}{l}\text { Nomes comuns referem-se aos } \\
\text { alimentos constantes do Anexo da RDC } \\
\text { no 26/2015 ( } 18 \text { alimentos). }\end{array}$ & \\
\hline & $\begin{array}{l}\text { Declaração "Alérgicos: Contém [nomes } \\
\text { comuns dos alimentos que causam } \\
\text { alergias alimentares] e derivados", } \\
\text { conforme o caso. }\end{array}$ & \multirow[t]{2}{*}{$\begin{array}{l}\text { Resolução RDC no 26, } \\
\text { de } 02 \text { de julho de } 2015 .\end{array}$} \\
\hline & $\begin{array}{l}\text { Nomes comuns referem-se aos } \\
\text { alimentos constantes do Anexo da RDC } \\
\text { no } 26 / 2015 \text { ( } 18 \text { alimentos). }\end{array}$ & \\
\hline $\begin{array}{l}\text { Possibilidade de contaminação } \\
\text { cruzada com alimentos } \\
\text { alergênicos e seus derivados }\end{array}$ & $\begin{array}{l}\text { Declaração "Alérgicos: Pode Conter } \\
\text { [nomes comuns dos alimentos que } \\
\text { causam alergias alimentares]". }\end{array}$ & $\begin{array}{l}\text { Resolução RDC no 26, } \\
\text { de } 02 \text { de julho de } 2015 .\end{array}$ \\
\hline $\begin{array}{l}\text { Presença da declaração } \\
\text { obrigatória nos rótulos de } \\
\text { alimentos embalados - "Contém } \\
\text { Glúten" ou "Não Contém Glúten" }\end{array}$ & $\begin{array}{l}\text { Declaração “Contém Glúten" ou “Não } \\
\text { Contém Glúten", conforme o caso. }\end{array}$ & $\begin{array}{l}\text { Lei } n \text { o } 10.674 \text {, de } 16 \text { de } \\
\text { maio de } 2003 \text {. }\end{array}$ \\
\hline
\end{tabular}

Continua... 
Quadro 3.1 - Categorias de requisitos legais da regulamentação técnica aplicável a alimentos embalados que causam alergias e seus derivados (cont.)

\begin{tabular}{|c|c|c|}
\hline Categoria de requisitos legais & Descrição & Regulamento Técnico \\
\hline \multirow{9}{*}{$\begin{array}{l}\text { Adequação da informação } \\
\text { obrigatória nos rótulos de } \\
\text { alimentos embalados alergênicos } \\
\text { e derivados em relação aos } \\
\text { parâmetros das regulamentações } \\
\text { aplicáveis }\end{array}$} & $\begin{array}{l}\text { "Expressão": informação sem apresentar } \\
\text { ambiguidade, vocábulos, sinais, símbolos } \\
\text { que induzam o consumidor ao equívoco }\end{array}$ & \multirow{9}{*}{$\begin{array}{l}\text { Resolução RDC no } 259 \text {, } \\
\text { de } 20 \text { de setembro de } \\
2002 \text {. } \\
\text { Resolução RDC no } 26 \text {, } \\
\text { de } 02 \text { de julho de } 2015 \\
\text { Lei no } 10.674 \text {, de } 16 \text { de } \\
\text { maio de } 2003 \text {. }\end{array}$} \\
\hline & $\begin{array}{l}\text { sobre a verdadeira natureza do produto } \\
\text { e com correta ortografia. }\end{array}$ & \\
\hline & & \\
\hline & $\begin{array}{l}\text { "Clareza": informação de fácil } \\
\text { interpretação, sem confundir a sua } \\
\text { correta leitura, com uma linguagem } \\
\text { clara. }\end{array}$ & \\
\hline & $\begin{array}{l}\text { "Visibilidade": informação disposta no } \\
\text { rótulo de forma nítida e em local visível } \\
\text { para que o consumidor consiga ver com } \\
\text { facilidade. }\end{array}$ & \\
\hline & $\begin{array}{l}\text { "Tamanho da letra": para as informações } \\
\text { obrigatórias de alimentos embalados, o } \\
\text { tamanho de letra deve ser igual ou } \\
\text { superior a } 1 \mathrm{~mm} \text {. }\end{array}$ & \\
\hline & $\begin{array}{l}\text { Para as declarações referentes a } \\
\text { alimentos alergênicos e derivados, o } \\
\text { tamanho da letra deve ser igual ou } \\
\text { superior a } 2 \text { mm e nunca inferior à altura } \\
\text { de letra utilizada na lista de ingredientes. }\end{array}$ & \\
\hline & $\begin{array}{l}\text { "Contraste de cor": informação disposta } \\
\text { no rótulo com contraste de cor que } \\
\text { assegure sua perfeita visibilidade, sem } \\
\text { prejuízo das informações e sem } \\
\text { atrapalhar a localização e leitura da } \\
\text { mesma. }\end{array}$ & \\
\hline & $\begin{array}{l}\text { "Realce": informação deve apresentar } \\
\text { realce ou destaque que atraia a atenção } \\
\text { do consumidor. }\end{array}$ & \\
\hline
\end{tabular}

Fonte: Elaboração própria.

Finalmente, as respostas à pergunta da Consulta Pública de interesse para a presente pesquisa foram de caráter geral, sem indicação de indicadores de MA, como solicitava a Anvisa. Esse fato vem confirmar o potencial de aplicação pela Agência dos resultados desta pesquisa - um conjunto de indicadores para monitoração e avaliação da regulamentação em foco, construídos com base na abordagem metodológica concebida pelo Ministério de Planejamento, Orçamento e Gestão, mas tendo como suporte de dois métodos multicritério de apoio à decisão - AHP e TOPSIS. 


\section{4 \\ Monitoramento e avaliação como instrumentos de gestão pública}

Este capítulo aborda as atividades de monitoramento e avaliação (MA) como instrumentos da gestão pública, abrangendo conceituação e função básica dos indicadores, além das diversas taxonomias descritas na literatura especializada. Descreve-se o método para construção de indicadores de MA, proposto pelo Ministério do Planejamento, Orçamento e Gestão (Brasil, 2010; 2012), como método de escolha para a fase aplicada da presente pesquisa. $\mathrm{Na}$ sequência, apresenta-se uma visão geral dos principais métodos multicritério de apoio à decisão, com destaque para o método analítico hierárquico (sigla em inglês, AHP) e a técnica TOPSIS, ambos selecionados para a fase seguinte desta pesquisa. O método AHP será aplicado para definir pesos dos critérios para classificar os indicadores de MA propostos para a regulamentação em foco; e a técnica TOPSIS apoiará a hierarquização final dos indicadores propostos para monitorar e avaliar a regulamentação de rotulagem de alimentos alergênicos e derivados no Brasil.

\section{1} Conceituação e função básica dos indicadores

Muitas são as definições de indicadores, sobretudo as contidas na literatura em MA, as quais estão próximas conceitualmente, como, Ferreira, Cassiolato e Gonzalez (2009) afirmam:

"O indicador é uma medida, de ordem quantitativa ou qualitativa, dotada de significado particular e utilizada para organizar e captar as informações relevantes dos elementos que compõem o objeto da observação. É um recurso metodológico que informa empiricamente sobre a evolução do aspecto observado."

A partir do ponto de vista do Instituto Brasileiro de Geografia e Estatística (IBGE, 2008), os indicadores são ferramentas construídas de variáveis que, relacionadas de formas distintas, podem expor e circundar significados mais completos sobre os elementos aos quais são referidos. 
Adicionalmente, Tanaka e Melo (2001) esclarecem um indicador como parte de uma variável, atributo ou característica de uma estrutura, processo ou resultado, que tem a capacidade de condensar, configurar ou dar significado às coisas que se desejam legitimar, e pode ser aceito em um contexto específico.

Conforme Bonnefoy e Armijo (2005), são duas as funções básicas dos indicadores, como segue:

- Função descritiva, que aborda informações sobre uma realidade empírica, situação social ou ação pública;

- Função valorativa, ou avaliativa, que agrega informação de valor à situação para avaliar a importância relativa ou a adequação de desempenho.

Os indicadores podem ser ainda classificados de acordo com diferentes momentos do ciclo de gestão, a saber, a partir do entendimento das funções supracitadas dessas funções:

- Ex-ante: antes da situação, dando suporte à definição do problema, ao desenho de uma política e estabelecimento das referências que se quer alterar;

- In curso: para o monitoramento e avaliação da situação, enquanto ela ocorre, revisão do planejamento inicial e correção das falhas e desvios;

- Ex-post: para avaliação do alcance de metas, resultados e impactos na sociedade.

Bonnefoy e Armijo (2005) atentam para a necessidade dos indicadores serem considerados nos diversos estágios da elaboração e na implementação propriamente dita de políticas, planos e programas. Adicionalmente, é preciso refletir a realidade do que se pretende calcular. Os critérios comumente adotados para definição e escolha de indicadores de MA são:

- Simplicidade: deve oferecer facilidade de entendimento para o público em geral nos tópicos de obtenção, construção, manutenção, comunicação;

- Clareza: é fundamental que o indicador seja objetivo nas necessidades que atende e que esteja documentado adequadamente, por mais complexo que possa parecer. Deve conter um vocabulário adequado e dentro do contexto do indicador;

- Sensibilidade: deve possuir um indicador para destacar eventuais mudanças, as quais resultam das intervenções feitas no indicador;

- Desagregabilidade: parte essencial da implementação de políticas públicas, já que, regionaliza grupos sociodemográficos; 
- Economicidade: potencialidade de o indicador otimizar os recursos para conseguir custos módicos, com resultados adquiridos favoráveis;

- Estabilidade: permite monitoramento e comparações entre variáveis de interesse, com pouca interferência causada por outras variáveis;

- Mensurabilidade: refere-se à mensuração quando é necessário, além de uma ótima precisão sem ambiguidade;

- Auditabilidade ou rastreabilidade: capacidade de averiguação do cumprimento das normas de uso dos indicadores e a adequada aplicação.

\section{2}

\section{Taxonomia dos indicadores}

Nesta seção, consideram-se como referências as classificações essenciais para o entendimento das taxonomias e uso na fase aplicada desta pesquisa.

Uma das classificações de indicadores mais importantes para os gestores de uma ação ou programa governamental é aquela referente à gestão do processo de implementação até a mensuração dos impactos para os diversos segmentos da sociedade beneficiados com os resultados da referida ação.

A Figura 3.1 apresenta uma das classificações mais importantes para a gestão de uma ação do governo. Tal classificação define indicadores adequados para cada etapa do processo, como ilustrado abaixo:

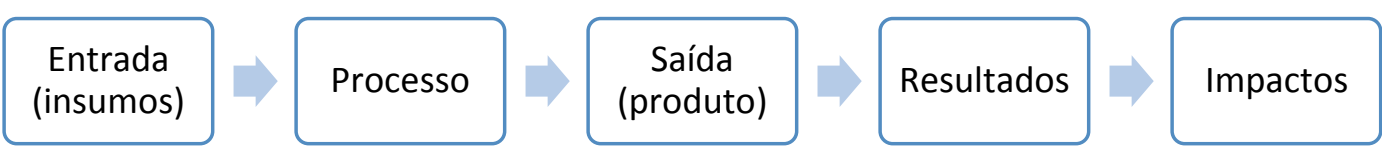

Figura 3.1 - Gestão do processo de implementação de um programa. Fontes: Armijo, 2011; Brasil, 2012.

Segundo Jannuzzi (2002), Bonnefoy e Armijo (2005) e Brasil (2012), os indicadores podem ser categorizados em:

- Indicadores de entrada: relacionados à direita com os recursos de investimentos, sejam humanos, materiais, financeiros ou outros também chamados ex-ante facto;

- Indicadores de processo: tratam-se de medidas que transcorrem no processo e resultados intermediários, medindo níveis de utilização, traduzindo a obtenção de resultados pretendidos;

- Indicadores de saída: referem-se às medidas ex-post facto, medindo metas físicas que expressam entrega, produtos e serviços a um público em específico; 
- Indicadores de resultado: citam medidas que expressam o comportamento dos proveitos direcionados direta ou indiretamente a um público específico;

- Indicadores de impacto: são indicadores abrangentes que permitem aferir estratégias governamentais de médio e longo prazo, além de serem multidimensionais.

A Figura 3.2 apresenta o ciclo de gestão de programas e iniciativas governamentais, que fundamentalmente compreendem as seguintes etapas (i) diagnóstico do problema ou demanda, (ii) planejamento, (iii) execução e monitoramento, (iv) avaliação; e (v) revisão.

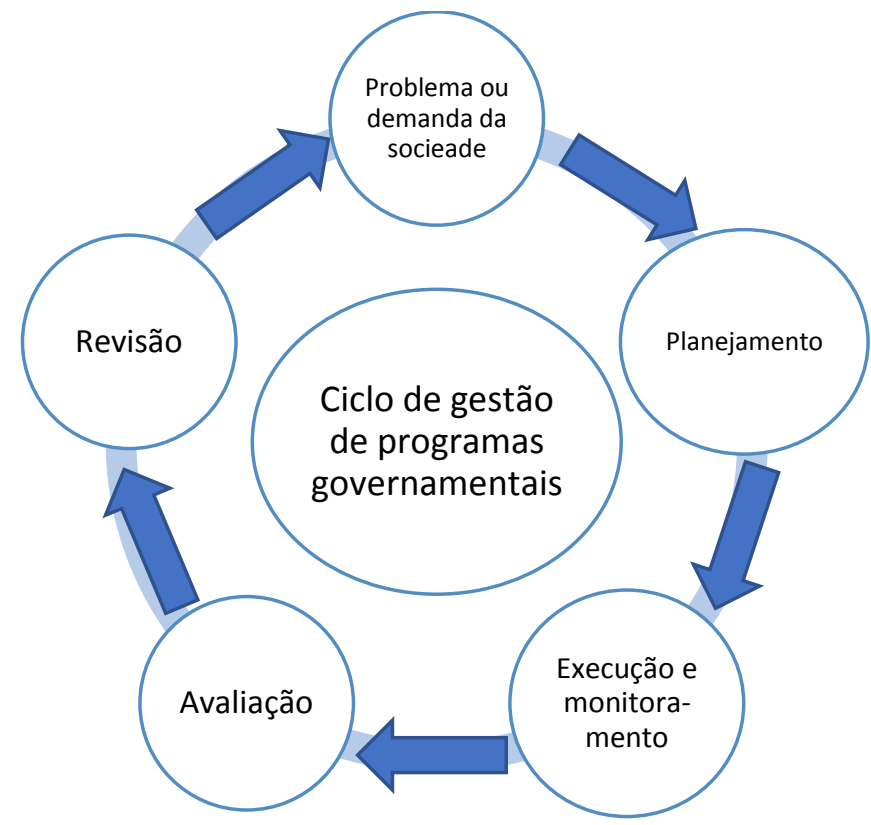

Figura 3.2 - Ciclo de gestão de programas governamentais Fonte: Brasil, 2010.

Cada etapa do ciclo apresentado na Figura 10 requer indicadores específicos, como ressaltado no Guia publicado pelo Ministério do Planejamento, Orçamento e Gestão, para construção de indicadores de MA voltados para a gestão pública (Brasil, 2010).

\section{3}

\section{Construção de indicadores}

Apresenta-se nesta seção um método genérico que visa orientar os gestores públicos na construção de indicadores de MA de programas, políticas e iniciativas 
governamentais em geral. O método foi concebido e divulgado pelo Ministério do Planejamento, Orçamento e Gestão, através do documento intitulado "Indicadores de Programas: Guia Metodológico" (Brasil, 2010).

Buscando-se incorporar conteúdos desse Guia Metodológico na construção de indicadores para monitorar e avaliar a regulamentação sobre rotulagem de alimentos alergênicos e derivados no Brasil, procedeu-se previamente a uma análise crítica desse método, comparando-o a outros trabalhos no campo de avaliação de programas (Weiss, 1972, 1998; Patton, 1978, 1980, 1982; Rich, 1977; Wholey, 1995; Stake, 1981; Alkin, Daillak e White, 1979; e Owen e Rogers, 1999).

Optou-se por adotar o método descrito no referido Guia na fase aplicada da presente pesquisa devido à inúmeros aspectos, como a confirmação da sua aplicabilidade em gestão pública e a viabildiade de construção no contexto da regulamentação em foco.. Cabe salientar que adaptações foram necessárias para a aplicação almejada (regulamentação sobre rotulagem de alimentos alergênicos e derivados).

O fluxograma da Figura 3.3 traduz esquematicamente o processo de elaboração de indicadores de um programa governamental genérico, em oito passos, conforme Brasil (2010).

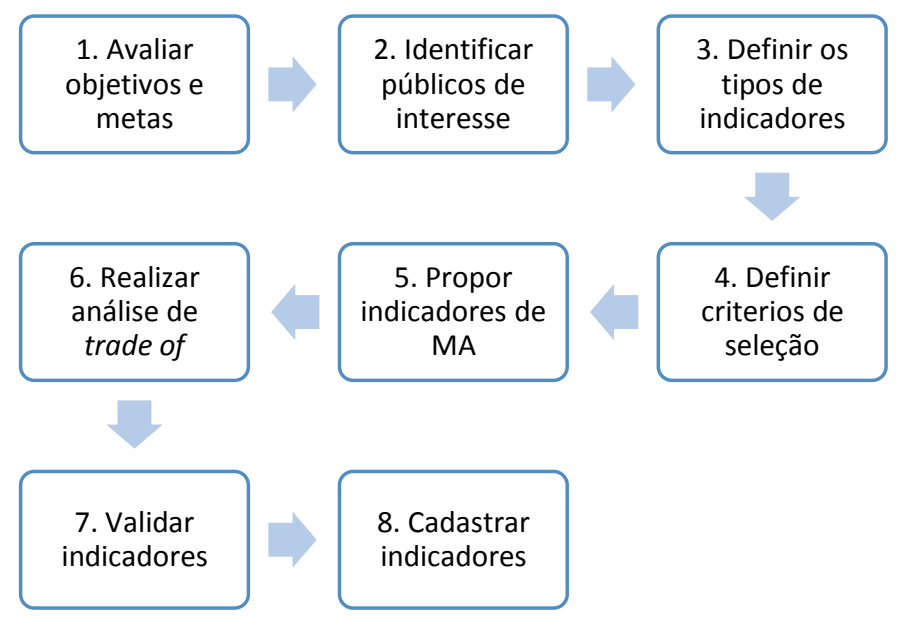

Figura 3 - Fluxograma de construção de indicadores Fonte: Brasil, 2010, p. 54.

A seguir, será descrito o processo de construção dos indicadores(oito passos), visando sua posterior execução na fase aplicada desta pesquisa (próximo capítulo). 
Para a construção de indicadores é preciso avaliar os objetivos e as metas do programa ou ação governamental, alvo de monitoramento e avaliação. A fim de garantir que os conceitos e as dimensões a serem abordados nas ações e subações sejam expressos por indicadores adequados, deve-se ter em mente entendimentos acerca dos objetivos do programa, bem como a ação governamental.

Uma vez adotado o método de construção do modelo lógico, como descrito na seção 3.1, é possível discernir diretamente as proporções de M\&A que devem ser consideradas, mediante a análise do enunciado do problema e das ações consideradas de maior pertinência.

O segundo passo está realacionado à identificação dos principais interessados nos resultados do programa/ação governamental em questão. É fundamental notar a relevância do tema para a sociedade, de maneira geral, julgando a existência de temas transversais que podem envolver outros setores do governo. Outrossim, é considerável assinalar a equipe gerencial responsável pela gestão do programa/ação, de modo que as informações essenciais para a mensuração de desempenho sejam direcionadas acertadamente.

O terceiro passo visa definir os tipos de indicadores, quais serão exigidos para a expressão dos resultados esperados e para atender aos interesses distintos dos interessados. A tipologia recomendada pelo Ministério do Planejamento, Orçamento e Gestão inclui os seguintes indicadores:

- Indicadores-chave: expressam o conceito ou a dimensão mais importante e relevante do objetivo proposto. Os programas, sobretudo os que oferecem bens e/ou serviços para a sociedade, devem apresentar, pelo menos, um indicador do tipo chave;

- Indicadores complementares: apresentam a dimensão mais importante, assim como as demais, além das contempladas nos escopo do Programa. Geralmente não devem ser interpretados isoladamente;

- Indicadores específicos: expõe as necessidades próprias de um ou outro público (identificados no passo dois) ou qualquer outra peculiaridade inerente ao conceito a ser aferido. São necessários, quando os outros dois tipos de indicadores anteriores não cumprem essa função.

O quarto passo depende da definição dos critérios de seleção, ou seja, aqueles que servirão de apoio para incluir ou descartar indicadores conforme os objetivos e conjuntura do programa/ação. Esses critérios podem ser de dois tipos, de acordo com Villela et al. (2007): 
- Critérios eliminatórios: devem ser obrigatoriamente atendidos pelo indicador candidato, tendo que ser descartado caso não atenda;

- Critérios classificatórios: usados para hierarquização dos indicadores, a partir de uma análise quantitativa ponderada.

Alguns dos critérios comumente utilizados para a seleção de indicadores são apresentados no Quadro 3.1.

Quadro 3.1 - Exemplos de critérios para seleção de indicadores

\begin{tabular}{l}
\hline Critérios para seleção de indicadores \\
\hline Atendimento às necessidades de informação dos interessados \\
\hline Confiabilidade da fonte \\
\hline Confiabilidade metodológica \\
\hline Desagregabilidade sociodemográfica \\
\hline Desagregabilidade espacial \\
\hline Disponibilidade quando necessário \\
\hline Economicidade de obtenção \\
\hline Estabilidade ao longo do tempo \\
\hline Existência de suporte técnico \\
\hline Facilidade de obtenção \\
\hline Mensurabilidade \\
\hline Objetividade \\
\hline Rastreabilidade ao longo do tempo \\
\hline Representatividade (em relação ao objetivo do programa) \\
\hline Sensibilidade à intervenção \\
\hline Simplicidade de construção e entendimento \\
\hline Tempestividade \\
\hline
\end{tabular}

Fonte: Brasil, 2010, p. 54.

Nota-se que são critérios universais e aplicáveis a qualquer realidade. Posto isto, quando aplicável, deverão ser definidas outras normas específicas e úteis ao conceito a ser medido.

Para instrumentalizar a aplicação dos critérios classificatórios, é preciso definir (i) o grau de atendimento dos indicadores candidatos aos critérios estabelecidos; (ii) atribuição de pesos aos critérios classificatórios, que podem variar de ação para ação, em conformidade com as especificidades de cada realidade.

Um exemplo da aplicação dos critérios classificatórios será apresentado adiante na descrição do sexto passo. 
O quinto passo serve para mapear indicadores 'candidatos' e deve-se, inicialmente, pesquisar, a temática em questão, indicadores e métricas prontas que apontem, com a maior proximidade possível, os conceitos postos nas intenções do programa/ação e que devem ser expressos na mensuração dos resultados aguardados.

Recomenda-se como boa prática a utilização do conhecimento e da experiência de especialistas nos temas abordados pelo programa/ação. Outras práticas, como o uso da técnica de brainstorming e grupos focais e análise de situações análogas, podem ser aplicados neste passo. Obtem-se, enquanto resultado, um repertório de indicadores 'candidatos', originários de várias fontes. A partir desse repertório realiza-se uma análise trade-off, que caracteriza o sexto passo

Para otimizar os resultados de uma análise desse tipo, realizam-se, em geral, duas análises encadeadas: uma quantitativa, seguida de outra qualitativa. Para tanto, é preciso escolher entre duas ou mais opções de indicadores. Ganha-se com a escolha de um indicador candidato, mas perde-se com a não escolha de outro. Conforme descrito no quarto passo, a análise quantitativa baseia-se na adoção de critérios objetivos. A ferramenta recomendada pelo Ministério do Planejamento, Orçamento e Gestão para viabilizar esse tipo de análise é a 'Matriz de avaliação quantitativa de indicadores', composta pelos seguintes elementos:

- Linhas: contemplam os indicadores que são candidatos à avaliação do comportamento do programa/ação;

- Colunas: contém informações sobre o tipo do indicador (se chave, complementar de resultado e/ou específico); a natureza do critério de seleção (se eliminatório ou classificatório); os julgamentos associados a cada indicador candidato quanto ao atendimento aos critérios eliminatórios e classificatórios; e o somatório dos pontos obtidos pelo indicador candidato, com sua posição na hierarquização final.

Para aplicação dos critérios eliminatórios, recomenda-se o preenchimento das células que representam a interseção da linha do indicador 'candidato' com a coluna do critério eliminatório, da seguinte forma: (i) não atende, indicado por $\mathbf{0}$; e (ii) atende, indicado por $\mathbf{1}$.

Acerca dos critérios classificatórios situam-se em duas colunas que representam (i), o grau de importância do critério (peso) no contexto do 
programa/ação; e (ii), o grau de atendimento do indicador candidato ao critério classificatório. Os autores do guia do Ministério do Planejamento, Orçamento e Gestão recomendam as seguintes escalas:

- Grau de importância do critério (peso): baixa (3); média (5); alta (7) e muito alta (9).

- Grau de atendimento do indicador ao critério: nenhum (0); atende parcialmente (1); e atende totalmente (2).

Para fins da aplicação da ferramenta "Matriz de avaliação quantitativa de indicadores" no âmbito desta pesquisa, optou-se pelas escalas sugeridas pelos autores de dois métodos multicritério de apoio à decisão, como será apresentado adiante.

A ferramenta apresentada permite que os indicadores sejam organizados em forma de um ranking, em ordem decrescente de pontos obtidos, em conformidade com o atendimento aos critérios pré-definidos (de $\mathrm{C} 1$ a C6).

A fórmula proposta pelo Minstério do Planejamento, Orçamento e Gestão para cálculo do total de pontos alcançado para cada indicador é:

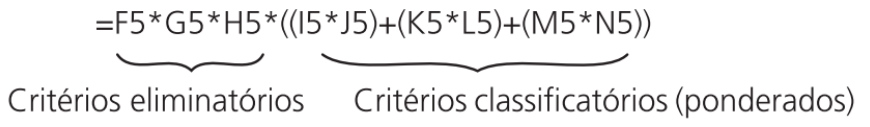

No que tange à aplicabilidade da ferramenta, "Matriz de avaliação quantitativa de indicadores" na presente pesquisa, optou-se pelo uso de uma ferramenta multicritério de apoio à decisão, intitulada TOPSIS, que será pormenorizada adiante.

A segunda análise a ser realizada é a qualitativa. A partir do ranking estabelecido pela "Matriz de avaliação quantitativa de indicadores", o gestor deve optar entre os indicadores de maior classificação, ou seja, aqueles que melhor expressam os resultados esperados pelo programa/ação em questão.

Os critérios utilizados geralmente são subjetivos, segundo experiências anteriores; opinião especializada; comparação com outros programas; indicações de instituições nacionais e internacionais; e quaisquer outras fontes consideradas relevantes.

Considerando-se ainda a perspectiva de melhoria contínua da gestão do programa/ação, ressalta-se que a análise qualitativa pode (i) verificar indicadores candidatos inicialmente ideais, mas que terminaram mal classificados ou mesmo 
eliminados pela análise quantitativa; (ii) checar as razões pelas quais esses indicadores foram reprovados e quais os critérios que não foram atendidos; (iii) realizar um plano de ação para excluir as restrições de uso desses indicadores; e (iv) comprometer-se na revisão dos indicadores do programa/ação, para que esses indicadores ideais possam ser aprovados e operacionalizados em um ciclo seguinte.

O sétimo passo refere-se à validação dos indicadores selecionados. Nesse passo, realiza-se uma verificação final da conformidade e pertinência dos indicadores, conforme o atendimento aos requisitos, optando pela seguinte lista de verificação: (i) os indicadores escolhidos são válidos para expressar os resultados esperados?; (ii) eles têm relação direta com os objetivos da ação governamental?; (iii) são originários de fontes confiáveis?; (iv) são mensuráveis?; (v) são em quantidade suficiente para expressar as dimensões envolvidas?; (vi) consideram a dimensão territorial quando necessária?; (vii) expressam questões transversais quando existirem?; (viii) as limitações inerentes aos indicadores foram consideradas?; e (ix) atendem ao critério de completude dos atributos exigidos para o seu cadastramento?.

Essa lista de verificação pode ser aplicada de forma total ou parcialmente, dependendo, portanto, do programa/ação. Além disso, em concordância com as respostas, é necessário examinar a pertinência dos indicadores selecionados ou revisar seu modelo lógico.

O último passo resume-se em cadastrar os indicadores escolhidos e suas respectivas métricas no sistema de informações gerenciais do órgão responsável pela gestão do programa/ação.

\section{3.}

\section{Métodos multicritério de apoio à decisão}

A tomada de decisão, principalmente no contexto da atual sociedade, no qual a competitividade é intensa e exige que os gestores utilizem instrumentos eficientes e flexíveis, é um dos grandes desafios apresentados a executivos e líderes, seja do setor público, seja do setor privado. Tal desafio torna-se complexo, uma vez observada a existência de variáveis subjetivas (inerentes do ser humano de maneira geral) e julgamentos de valor. Os métodos multicritério de apoio à decisão (MMAD) têm o objetivo de proporcionar a modelagem para a 
solução de problemas de gestão, caracterizando-se como um instrumental relevante e de uso crescente nos ambientes organizacionais (Costa, 2006).

\subsection{1.}

\section{Visão geral e quadro comparativo}

MMAD trata-se de um conjunto de técnicas desenvolvidas para auxiliar um decisor (seja ele caracterizado por uma pessoa, grupo político, grupo de técnicos, entre outros) a analisar um problema complexo, de resolução trabalhosa e com distintas alternativas de solução, em concordância com determinados critérios (Sousa Junior e Mendes, 2014). Para mais, os instrumentos devem ter habilidades para tratar eventuais adversidades; com simplicidade, para que sejam acessíveis aos decisores, sem que eles tenham que empregar excesso de tempo e dinheiro para utilizá-los (Costa, 2006).

O Quadro 3.2 apresenta os principais MMAD, com a inclusão das referências bibliográficas, além das vantagens e desvantagens de sua aplicação.

Há diversos MMAD, entretanto, os mais utilizados são "Utilidade Multiatributo", "Processo Analítico Hierárquico" (sigla em inglês, AHP); Elimination et Choix Traduisant la Realite (ELECTRE) é a "Técnica para avaliar o desempenho de alternativas através de similaridade com a solução ideal" (sigla em inglês, TOPSIS) (Gomes e Freitas Junior, 2000).

$\mathrm{Na}$ fase de pesquisa aplicada, cujos resultados serão exibidos no capítulo 5, foram utilizados dois dos métodos listados, a saber, o "Processo Analítico Hierárquico" (AHP) e a "Técnica para avaliar o desempenho de alternativas, através de similaridade com a solução ideal” (TOPSIS). 
Quadro 3.2 - Quadro-resumo dos métodos multicritério de apoio à decisão

\begin{tabular}{|c|c|c|}
\hline Ferramenta AMD & Vantagens & Desvantagens \\
\hline $\begin{array}{l}\text { Processo Analítico } \\
\text { Hierárquico (Analytical } \\
\text { Hierarchy Process - AHP) } \\
\text { (Saaty, 1977; 1990; 1991; } \\
\text { 2000) }\end{array}$ & $\begin{array}{l}\text { - Modelo simples para construir; } \\
\text { - Processo lógico; } \\
\text { - Eficiente em lidar com atributos } \\
\text { qualitativos e quantitativos; } \\
\text { - Resultados de fácil entendimento. }\end{array}$ & $\begin{array}{l}\text { - Dúvidas têm sido levantadas } \\
\text { sobre a fundamentação dessa } \\
\text { teoria. Existe uma forte visão de } \\
\text { que os axiomas em que o AHP se } \\
\text { baseia não são suficientemente } \\
\text { claros para serem empiricamente } \\
\text { testados. }\end{array}$ \\
\hline $\begin{array}{l}\text { Técnica para avaliar o } \\
\text { desempenho de alternativas } \\
\text { através de similaridade com } \\
\text { a solução ideal (Technique } \\
\text { for Order Preference by } \\
\text { Similarity to Ideal Solution - } \\
\text { TOPSIS) } \\
\text { (Hwang e Yoon, 1981) }\end{array}$ & $\begin{array}{l}\text { - A consistência interna e solidez lógica; } \\
\text { - Fácil de seguir; } \\
\text { - Intuitivamente atraente; } \\
\text { - Não há cálculos complicados; } \\
\text { - Facilmente configurado em MS Excel; } \\
\text { - Os resultados são de fácil } \\
\text { entendimento; } \\
\text { - Valor do índice simples dado; } \\
\text { - Os resultados podem ser facilmente } \\
\text { demonstrados graficamente. }\end{array}$ & $\begin{array}{l}\text { - Grande número de } \\
\text { procedimentos; } \\
\text { - Grande número de cálculos; } \\
\text { - } \text { Fornece um resultado geral. }\end{array}$ \\
\hline $\begin{array}{l}\text { Preference Ranking Method } \\
\text { for Enrichment Evaluation - } \\
\text { PROMETHEE } \\
\text { (Brans e Vincke, 1984) }\end{array}$ & $\begin{array}{l}\text { - Incentiva mais interação entre o } \\
\text { decisor e o modelo, na procura de boas } \\
\text { opções; } \\
\text { - Os defensores argumentam que o seu } \\
\text { conceito outranking é mais relevante } \\
\text { para situações práticas do que o } \\
\text { conceito de dominação restritiva. }\end{array}$ & - Muito conhecimento necessário. \\
\hline 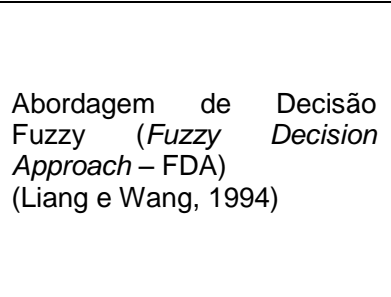 & $\begin{array}{l}\text { - É baseada em palavras e não em } \\
\text { números, expresso linguisticamente; } \\
\text { - Melhor tratamento das imprecisões; } \\
\text { - Facilidade na especificação das } \\
\text { regras; } \\
\text { - O uso de variáveis linguísticas deixa } \\
\text { mais perto do pensamento humano; } \\
\text { - Requer poucas regras, poucos valores } \\
\text { e poucas decisões. }\end{array}$ & $\begin{array}{l}\text { - Construção complexa; } \\
\text { - A lógica fuzzy é bastante } \\
\text { imprecisa; } \\
\text { - Dificuldade em prever qual será a } \\
\text { interação entre as diferentes } \\
\text { condicionantes do problema. }\end{array}$ \\
\hline $\begin{array}{l}\text { Métodos ELimination Et } \\
\text { Choix TRaduisant la rEalité - } \\
\text { ELECTRE } \\
\text { (Roy e Bouyssou, 1993) }\end{array}$ & $\begin{array}{l}\text { - Os defensores argumentam que o seu } \\
\text { conceito outranking é mais relevante a } \\
\text { situações práticas do que o conceito de } \\
\text { dominação restritiva; } \\
\text { - Pode ser usado para escolher, } \\
\text { classificar, e ordenar alternativas. }\end{array}$ & $\begin{array}{l}\text { - Muito conhecimento necessário. } \\
\text { - Não é transparente; } \\
\text { - Muito provavelmente será } \\
\text { necessário um especialista em } \\
\text { AMD para ajudar e realizar a } \\
\text { análise. }\end{array}$ \\
\hline $\begin{array}{l}\text { Measuring Attractiveness by } \\
\text { a Categorical Based } \\
\text { Evaluation Technique - } \\
\text { MACBETH } \\
\text { (Bana Costa e Vasnick, } \\
\text { 1994) }\end{array}$ & $\begin{array}{l}\text { - Julgamento comparativo dos decisores } \\
\text { entre os diversos critérios e ações; } \\
\text { - É utilizado um software especializado } \\
\text { que fornece os pesos dos critérios de } \\
\text { acordo com os julgamentos feitos; } \\
\text { - A principal vantagem desta técnica é } \\
\text { maneira como os decisores expressam } \\
\text { suas preferências, de forma qualitativa. }\end{array}$ & $\begin{array}{l}\text { - O software pode não conseguir } \\
\text { gerar resultados compatíveis com } \\
\text { as comparações realizadas e } \\
\text { sugere variações de julgamentos } \\
\text { que permitam a aproximação de } \\
\text { um resultado; } \\
\text { - A possibilidade de se tornar um } \\
\text { método cansativo caso haja } \\
\text { necessidade de um grande } \\
\text { número de comparações. }\end{array}$ \\
\hline
\end{tabular}

Fonte: Adaptado de Keeney e Raiffa (1976); Saaty (1977; 1990; 1991; 2000); Hwang e Yoon (1981); Brans, Mareschal e Vincke (1984); Liang e Wang (1994); Roy e Bouyssou (1993); Bana e Costa e Vasnick (1994), apud Sousa Junior (2013).

\subsection{2. \\ Processo Analítico Hierárquico (AHP)}

O método AHP foi proposto por Saaty nos anos 1970, sendo um dos métodos de AMD mais populares e usados. De mais a mais, é uma das ferramentas de apoio multicritério para a tomada de decisão que revela o maior número de aplicações práticas presentes na literatura, tais como engenharia, 
educação, indústria e setores do governo, para desvendar problemas pertinentes à seleção e avaliação subjetiva de alternativas (Dutra e Fogliatto, 2007).

A decomposição e a síntese das relações entre critérios são os fundamentos do método AHP que possibilita chegar a uma priorização dos critérios, que estarão mais próximos para a convergência à melhor resposta de medição única (Saaty, 1977; 1990; 1991; 2000). Resumidamente, o cerne da teoria está centrado no estudo de sistemas a partir de uma série de comparações aos pares. Saaty considera que este é o método natural de funcionamento porque a mente humana tem a mesma atividade: frente a um grande número de elementos, ela executa comparações e os agrupa conforme determinada propriedade, repetindo esse processo para outros níveis, até atingir seu máximo, quando a repetição representa o objetivo do processo decisório, revelando, então, uma hierarquia.

Através de comparações por pares, diz Saaty (1991), é a forma mais racional para realizar os julgamentos porque assim as prioridades calculadas pelo método irão capturar tanto as medidas subjetivas, quanto as objetivas, revelando fielmente a intensidade de domínio de um determinado critério (ou alternativa) em relação ao outro.

Utilizar o método é eficaz nas tomadas de decisões, porque minimiza os seus defeitos e, como são realizados julgamentos de comparações pareadas ancoradas em experiência, intuição e dados reais, trata dos aspectos quantitativos e qualitativos de um determinado problema (Saaty, 1991).

Para melhor elucidar, o método AHP converte o problema maior em avaliações mais compreensíveis e de menor relevância, mantendo, portanto, a participação desses últimos na decisão global. Ou seja, a situação-problema é dividida em partes menores e quando forem solucionadas, uma a uma (posteriormente somados), devem representar a decisão a ser tomada para a resolução do problema inicial.

Segundo Costa (2006), o método está sustentado em três princípios do pensamento analítico:

- Construção de hierarquias, que reflete o momento em que o problema é organizado a partir de níveis hierárquicos, possibilitando ser mais bem assimilado e avaliado. Caracteriza uma etapa importante do raciocínio humano no qual estão identificados os elementos chave para a tomada de decisão; 
- Definição das prioridades, fundamentada na capacidade de relacionamento do ser humano, com objetos ou situações observadas, equiparadas aos pares em relação a um determinado foco ou critério;

- Consistência lógica, que pode ser avaliada depois de aplicado o método.

O método AHP concebe quatro etapas, segundo a descrição de Saaty (1991) e Costa (2006). A descrição detalhada do método AHP encontra-se no Anexo 1.

\subsection{3. \\ Técnica para avaliar o desempenho de alternativas pela similaridade com a solução ideal (TOPSIS)}

A técnica para examinar o desempenho de opções pela similaridade com a solução ideal (em inglês, technique for order preference by similarity to ideal solution ou TOPSIS) foi introduzida por Hwang e Yoon, em 1981. Desde então, vem sendo aplicada por pesquisadores de áreas distintas, como, por exemplo, gestão da cadeia de suprimentos, design e sistemas de produção, gestão ambiental e de saúde. O método se vale de uma análise de entropia na definição dos pesos utilizados.

Uma série de características fazem com que a técnica TOPSIS seja a ferramenta de escolha para a solução de múltiplos problemas, destacados por Amiri et al. (2010):

- Autoriza a inclusão de um número ilimitado de propriedades e atributos;

- Permite, da mesma forma, trabalhar dentro de contextos específicos, nos quais cada atributo não pode ser avaliado individualmente e sim como uma troca em relação a outros;

- Estabelece as alternativas através de escores, o que facilita o entendimento das diferenças e similaridades entre elas;

- Implementa em planilha eletrônica, facilitando a sua utilização.

Assim, com essa técnica, a melhor alternativa seria aquela mais próxima da solução ideal positiva (positive ideal solution ou PIS) e a mais distante da solução ideal negativa (negative ideal solution ou NIS). A solução ideal positiva é composta por todos os melhores valores atingíveis em relação a cada critério. Todavia, a solução ideal negativa, evidencia os piores valores atingíveis em relação a cada critério de decisão (Hwang e Yoon, 1981).

A descrição detalhada do método TOPSIS encontra-se no Anexo 2. 


\section{4. \\ Considerações finais sobre o capítulo}

Os indicadores são formas quantificáveis de se representar características de produtos e processos. Os efeitos das ações devem ser aferidos de alguma forma, de modo que o gerenciamento de um dado programa ou ação governamental seja realizado de forma eficaz. Os indicadores consentem avaliar resultados positivos e negativos, servem de base para uma decisão, verificam posição em relação às metas, melhoram processos, medem desempenho, entre diversas outras funções. Os indicadores devem ser bem definidos, acompanhados sistematicamente para tomada de decisão e aplicáveis ao que de fato for relevante para serem utilizados da melhor maneira possível.

Destacaram-se neste capítulo a metodologia para elaboração do modelo lógico, proposta pelo Instituto de Pesquisa Econômica Aplicada (Ipea) para organizar avaliações dos programas que integram o Plano Plurianual (PPA) e o método de construção de indicadores de MA, divulgado pelo Ministério do Planejamento, Orçamento e Gestão.

Cabe ressaltar que o método para construção da matriz de indicadores de MA foi concebido para dar suporte à definição de indicadores e métricas para avaliar o desempenho de Programas do PPA do Governo Federal. Poderá ser adotado com pequenas adequações, na construção de indicadores para monitorar e examinar a regulamentação sobre rotulagem de alimentos alergênicos e derivados no Brasil - objeto desta dissertação.

Espera-se o resultado de cada etapa da aplicação da regulamentação da Anvisa e como esses resultados poderão ser mensurados e aferidos em tempo hábil. Particularmente, o "Guia para Construção de Indicadores de MA", difundido pelo Ministério do Planejamento, Orçamento e Gestão, mostrou-se extremamente proficiente para a compreensão e escolha de indicadores e métricas iniciais, na perspectiva de que de fato pudessem expressar os resultados esperados com a regulamentação sobre rotulagem de alimentos alergênicos e derivados no Brasil.

A parte final do capítulo abordou métodos multicritério de apoio à decisão, para fins de opção daqueles a serem adotados na fase de pesquisa aplicada, sobretudo na definição de pesos dos critérios para classificar indicadores 
candidatos e na etapa final de hierarquização dos indicadores selecionados para monitorar e avaliar a regulamentação sobre rotulagem de alimentos alergênicos e derivados no Brasil.

Os métodos quantitativos multicritério de apoio à decisão têm sido empregados em uma série de aplicações, de acordo com o comentário da seção 4.3. A partir de uma visão comparativa de seis métodos, o AHP, desenvolvido por Thomas A. Saaty, em 1977, e a ferramenta TOPSIS, proposta por Hwang e Yoon, em 1981, mostraram-se os mais apropriados para aplicação nas referidas etapas da fase de pesquisa aplicada deste trabalho.

O método adotado, na etapa de definição dos pesos dos critérios classificatórios para hierarquização final dos indicadores de MA da regulamentação em foco (Seção 5.4), será o AHP. A técnica TOPSIS, por outro lado, será aplicada para a hierarquização final dos indicadores endereçados à ANVISA (Seção 5.5).

Finalmente, considera-se que a integração dos métodos AHP e TOPSIS à metodologia que vem sendo adotada pelo Ministério do Planejamento, Orçamento e Gestão possam cooperar para o aperfeiçoamento da prática atual, que consiste na construção de indicadores de MA em diversos contextos da gestão pública. 


\section{5 \\ Indicadores para monitoramento e avaliação da regulamentação sobre rotulagem de alimentos alergênicos e derivados}

Este capítulo tem por objetivo relatar e discutir os resultados da fase aplicada da pesquisa até a proposição de um conjunto de indicadores para monitoramento e avaliação (MA) da regulamentação sobre rotulagem de alimentos alergênicos e derivados no Brasil, respondendo a questão principal da dissertação.

Inicialmente, apresenta-se o processo de construção da matriz quantitativa de indicadores de MA para a regulamentação em foco, que seguiu a abordagem metodológica apresentada e discutida no capítulo anterior. Em particular, descreve-se como foram propostos os indicadores de MA iniciais, a partir da análise das categorias de requisitos legais constantes da RDC $\mathrm{n}^{\circ}$ 26/2015 e de outros regulamentos de rotulagem aplicáveis, incluindo-se a realização de um préteste da ferramenta. Na sequência, apresentam-se os resultados da aplicação do método de processo analítico hierárquico (sigla em inglês, AHP) para definição dos pesos dos critérios de classificação dos indicadores propostos na etapa anterior e do uso da técnica TOPSIS para hierarquizar, por categoria de requisitos legais, os indicadores de MA da regulamentação em foco.

\section{1}

Construção da matriz de indicadores de MA para a regulamentação em foco

Embora a abordagem metodológica do Ministério do Planejamento, Orçamento e Gestão (Brasil, 2010) tenha sido voltada para a definição de indicadores de monitoramento e avaliação para o Plano Plurianual (PPA) do Governo Federal, pode-se tomar o documento "Indicadores de Programas: Guia Metodológico" (Brasil, 2010) como referência para a construção da matriz inicial de avaliação quantitativa de indicadores de MA para a regulamentação em foco. Dessa forma e com algumas adaptações, foram realizados na fase aplicada da 
presente pesquisa os passos 1 a 6 do processo de construção da matriz, como descrito no capítulo 4. É importante ressaltar que os passos 7 e 8 (validação e cadastramento dos indicadores) não integram o escopo desta pesquisa, uma vez que deverão ser realizadas posteriormente pelo órgão regulador - Anvisa.

A construção da matriz de avaliação quantitativa de indicadores de MA teve como ponto de partida a caracterização das categorias de requisitos legais de rotulagem, identificando-se as questões relevantes a serem avaliadas em cada categoria. Os indicadores inicialmente propostos para cada categoria foram posteriormente selecionados e hierarquizados com suporte de métodos multicritério de apoio à decisão, como o AHP e a técnica TOPSIS (ver seções 5.3 e 5.4).

O Quadro 5.1 reúne as bases para a construção da matriz de avaliação quantitativa de indicadores de MA para a regulamentação sobre rotulagem de alimentos alergênicos e derivados no Brasil.

Quadro 5.1 - Bases para a construção da matriz de indicadores de MA da regulamentação sobre rotulagem de alimentos alergênicos e derivados no Brasil

\begin{tabular}{|c|c|c|}
\hline $\begin{array}{l}\text { Objetivo da } \\
\text { regulamentação }\end{array}$ & $\begin{array}{l}\text { Categoria de requisitos } \\
\text { legais }\end{array}$ & $\begin{array}{l}\text { Informação a ser apresentada no rótulo do } \\
\text { alimento alergênico }\end{array}$ \\
\hline \multirow{12}{*}{$\begin{array}{l}\text { Garantir que os } \\
\text { consumidores } \\
\text { tenham acesso a } \\
\text { informações } \\
\text { corretas, } \\
\text { compreensíveis e } \\
\text { visíveis dos } \\
\text { principais } \\
\text { alimentos } \\
\text { embalados que } \\
\text { causam alergias } \\
\text { alimentares. }\end{array}$} & \multirow{8}{*}{$\begin{array}{l}\text { Presença das informações } \\
\text { obrigatórias nos rótulos de } \\
\text { alimentos embalados, } \\
\text { incluindo alergênicos e } \\
\text { derivados, conforme } \\
\text { Resolução RDC no } 259 \text {, de } 20 \\
\text { de setembro de } 2002 \text {. }\end{array}$} & Denominação de venda do alimento. \\
\hline & & Lista de ingredientes. \\
\hline & & Conteúdos líquidos. \\
\hline & & Identificação da origem. \\
\hline & & $\begin{array}{l}\text { Nome ou razão social e endereço do importador, } \\
\text { no caso de alimentos importados. }\end{array}$ \\
\hline & & Identificação do lote. \\
\hline & & Prazo de validade. \\
\hline & & $\begin{array}{l}\text { Instruções sobre preparo e uso do alimento, } \\
\text { quando necessário. }\end{array}$ \\
\hline & \multirow{3}{*}{$\begin{array}{l}\text { Presença intencional de } \\
\text { alimentos alergênicos e seus } \\
\text { derivados, conforme } \\
\text { Resolução RDC no } 26 \text {, de } 02 \\
\text { de julho de } 2015 \text {. }\end{array}$} & $\begin{array}{l}\text { Declaração “Alérgicos: Contém [nomes comuns } \\
\text { dos alimentos que causam alergias alimentares]". }\end{array}$ \\
\hline & & $\begin{array}{l}\text { Declaração "Alérgicos: Contém derivados de } \\
\text { [nomes comuns dos alimentos que causam alergias } \\
\text { alimentares]". }\end{array}$ \\
\hline & & $\begin{array}{l}\text { Declaração “Alérgicos: Contém [nomes comuns } \\
\text { dos alimentos que causam alergias alimentares] e } \\
\text { derivados", conforme o caso. }\end{array}$ \\
\hline & $\begin{array}{l}\text { Possibilidade de } \\
\text { contaminação cruzada com } \\
\text { alimentos alergênicos e seus } \\
\text { derivados, conforme } \\
\text { Resolução RDC no } 26 \text {, de } 02 \\
\text { de julho de } 2015 \text {. }\end{array}$ & $\begin{array}{l}\text { Declaração “Alérgicos: Pode Conter [nomes } \\
\text { comuns dos alimentos que causam alergias } \\
\text { alimentares]". }\end{array}$ \\
\hline
\end{tabular}

Continua... 
Quadro 5.1 - Bases para a construção da matriz de indicadores de MA da regulamentação sobre rotulagem de alimentos alergênicos e derivados no Brasil (cont.)

\begin{tabular}{|c|c|c|}
\hline $\begin{array}{l}\text { Objetivo da } \\
\text { regulamentação }\end{array}$ & $\begin{array}{l}\text { Categoria de requisitos } \\
\text { legais }\end{array}$ & $\begin{array}{c}\text { Informação a ser apresentada no rótulo do } \\
\text { alimento alergênico }\end{array}$ \\
\hline \multirow{7}{*}{$\begin{array}{l}\text { Garantir que os } \\
\text { consumidores } \\
\text { tenham acesso a } \\
\text { informações } \\
\text { corretas, } \\
\text { compreensíveis e } \\
\text { visíveis dos } \\
\text { principais } \\
\text { alimentos } \\
\text { embalados que } \\
\text { causam alergias } \\
\text { alimentares. }\end{array}$} & $\begin{array}{l}\text { Presença da declaração } \\
\text { obrigatória nos rótulos de } \\
\text { alimentos embalados - } \\
\text { "Contém Glúten" ou "Não } \\
\text { Contém Glúten" - conforme } \\
\text { a Lei no } 10.674 \text {, de } 16 \text { de } \\
\text { maio de } 2003 \text {. }\end{array}$ & $\begin{array}{l}\text { Declaração “Contém Glúten” ou “Não Contém } \\
\text { Glúten”, conforme o caso. }\end{array}$ \\
\hline & \multirow{6}{*}{$\begin{array}{l}\text { Adequação da informação } \\
\text { obrigatória nos rótulos de } \\
\text { alimentos embalados } \\
\text { alergênicos e derivados em } \\
\text { relação aos parâmetros das } \\
\text { regulamentações aplicáveis }\end{array}$} & $\begin{array}{l}\text { Adequação de uma ou mais informações } \\
\text { obrigatórias do rótulo em relação ao parâmetro } \\
\text { "expressão". }\end{array}$ \\
\hline & & $\begin{array}{l}\text { Adequação de uma ou mais informações } \\
\text { obrigatórias do rótulo em relação ao parâmetro } \\
\text { "clareza". }\end{array}$ \\
\hline & & $\begin{array}{l}\text { Adequação de uma ou mais informações } \\
\text { obrigatórias do rótulo em relação ao parâmetro } \\
\text { "visibilidade". }\end{array}$ \\
\hline & & $\begin{array}{l}\text { Adequação de uma ou mais informações } \\
\text { obrigatórias do rótulo em relação ao parâmetro } \\
\text { "tamanho da letra". }\end{array}$ \\
\hline & & $\begin{array}{l}\text { Adequação de uma ou mais informações } \\
\text { obrigatórias do rótulo em relação ao parâmetro } \\
\text { "contraste de cor". }\end{array}$ \\
\hline & & $\begin{array}{l}\text { Adequação de uma ou mais informações } \\
\text { obrigatórias do rótulo em relação ao parâmetro } \\
\text { "realce". }\end{array}$ \\
\hline
\end{tabular}

Fonte: Elaboração própria.

Apresentam-se, a seguir, os resultados da construção da matriz de avaliação quantitativa de indicadores de MA (passos 1 a 6 da metodologia do Ministério do Planejamento, Orçamento e Gestão (Brasil, 2010).

\subsection{1}

Avaliação do objetivo da regulamentação e resultados esperados

O primeiro passo da metodologia adotada foi avaliar o objetivo e os resultados esperados com a implementação da regulamentação sobre rotulagem de alimentos alergênicos e derivados. A partir desse entendimento, identifcaram-as os aspectos da regulamentação que deveriam ser alvo de monitoramento e avaliação, associando-os às cinco categorias de requisitos legais como apresentado no Quadro 5.1.

O Quadro 5.2 sintetiza os resultados desta avaliação, que contemplou as evidências da existência do problema; os objetivos da regulamentação como estabelecido na proposta da RDC $n^{\circ} 26$ pela Anvisa, em 2014; os principais 
resultados esperados e aspectos da regulamentação que devem ser considerados para fins de monitoramento e avaliação.

Quadro 5.2 - Síntese da avaliação dos objetivos da regulamentação e resultados esperados

\begin{tabular}{ll}
\hline Componentes & Descrição \\
\hline Casos de evidências da & - Casos recentes por alergias alimentares no Brasil; \\
existência do problema & - Código de defesa do consumidor não atinge especificidades sobre \\
& rotulagem de alimentos alergênicos; \\
& - Reclamações por parte de consumidores à autoridade sanitária local e \\
& regional; \\
& - Falta de comunicação entre os fabricantes/importadores aos \\
& consumidores; \\
& Risco de danos na saúde dos consumidores; \\
& - Consumidores com hipersensibilidade são os diretamente afetados.
\end{tabular}

Objetivo da

regulamentação

Garantir que os consumidores tenham acesso a informações corretas, compreensíveis e visíveis dos principais alimentos embalados que causam alergias alimentares.

Resultados esperados - Informações corretas, compreensíveis e visíveis para permitir o gerenciamento do risco por parte dos indivíduos alérgicos na compra e consumo de alimentos embalados;

- Redução significativa dos casos de alergias alimentares no Brasil;

- Conscientização do problema pelos atores envolvidos na cadeia de produção de alimentos;

- Menor número possível de não conformidades nos rótulos de alimentos embalados referentes a informações sobre alimentos que causam alergias.

Categorias de requisitos legais que deverão ser objeto de monitoramento e avaliação
- Presença das informações obrigatórias gerais nos rótulos de alimentos embalados alergênicos e derivados, conforme Resolução RDC no 259, de 20 de setembro de 2002.

- Presença intencional de alimentos alergênicos e seus derivados, conforme Resolução RDC no 26, de 02 de julho de 2015.

- Possibilidade de contaminação cruzada com alimentos alergênicos e seus derivados, conforme Resolução RDC no 26, de 02 de julho de 2015.

- Presença da declaração obrigatória "Contém Glúten" ou "Não Contém Glúten" nos rótulos de alimentos embalados, conforme a Lei no 10.674 , de 16 de maio de 2003.

- Adequação da informação obrigatória nos rótulos de alimentos embalados alergênicos e derivados em relação aos parâmetros das regulamentações aplicáveis.

Fonte: Elaboração própria.

Aplicando-se a lógica SMART, acrônimo em inglês que significa "eSpecífico"; "Mensurável"; "Alcançável"; "Relevante" e “Tempo" (Locke e Latham, 1979; 1990; 2002; 2006; Doran, 1981), foi possível verificar se o enunciado do objetivo da regulamentação encontrava-se expresso de forma objetiva e clara, tendo em vista sua efetiva implementação:

- ESpecífico: não se trata de um objetivo genérico. Está bem caracterizado, focado na regulamentação de rotulagem de alimentos alergênicos e é de alcance no contexto de um sistema nacional de rotulagem de alimentos embalados, como recomenda o Codex Alimentarius;

- Mensurável: é passível de aferição com indicadores e métricas que expressem realidade, como por exemplo, percentual de rótulos não 
conformes em relação ao número de rótulos de produtos embalados por categoria ou região;

- Alcancável: o objetivo é realista e viável, caso a estratégia de implementação pela Anvisa seja adequada e suficiente;

- Relevante: relaciona problemas identificados (principalmente a declaração nos rótulos das advertências de alimentos alergênicos e fiscalização por parte da Anvisa). Além disso, está alinhado às atribuições da Anvisa no que se refere à segurança alimentar;

- Tempo: o objetivo é passível de planejamento e progamação da fase de transição, podendo-se assim estimar um tempo para ser atingido.

\section{1 .2}

\section{Identificação das partes interessadas}

De acordo com a abordagem metodológica do Ministério do Planejamento, Orçamento e Gestão (Brasil, 2010), torna-se necessário identificar os principais interessados da regulamentação a ser monitorada e avaliada (passo 2 da metodologia).

A regulamentação sobre rotulagem de alimentos alergênicos traz benefícios e impactos para as seguintes partes interessadas:

- Agência Reguladora, a Anvisa, responsável pela formulação do regulamento técnico (RDC) e monitoramento e avaliação dos resultados da sua implementação;

- Órgãos de Vigilância Sanitária estaduais e municipais (Visa), que deverão realizar a fiscalização dos rótulos de alimentos embalados, especificamente das informações sobre os principais alimentos que causam alergias alimentares;

- Fabricantes e importadores de alimentos, responsáveis pela fabricação ou disponibilização de alimentos com possíveis ingredientes alergênicos. De acordo com a regulamentação em foco serão responsáveis pelas declarações requeridas de forma objetiva e legível;

- Consumidores alérgicos terão acesso a informações objetivas e legíveis sobre a presença de alimentos alergênicos nos rótulos dos alimentos embalados, de forma a gerenciar o risco à saúde.

\subsection{3}

\section{Definição dos tipos de indicadores}

No passo 3, definiram-se os tipos de indicadores que serão obrigatórios para atender diferentes interesses identificados no passo 2, além de expressar os resultados esperados. 
Seguindo-se a tipologia recomendada pelo Ministério de Planejamento, Orçamento e Gestão (Brasil, 2010), os indicadores foram classificados em:

- Indicadores-chave: refletem o conceito mais importante de um ou mais requisitos legais que deverão ser objeto de monitoramento e avaliação da rotulagem de alimentos que causam alergia;

- Indicadores complementares: complementam os indicadores- chave, proporcionando confiabilidade da mensuração e rastreabilidade da informação;

- Indicadores específicos: além de expressar necessidades próprias de determinados interessados específicos do tema em contexto, questões especificamente ao MA da regulamentação em foco.

\subsection{4}

\section{Definição dos critérios de seleção dos indicadores}

O passo 4 consistiu na definição dos critérios de seleção de indicadores. Como foi abordado na seção 4.1.4, os critérios foram classificados em:

- Critérios eliminatórios: devem ser obrigatoriamente atendidos pelo indicador proposto (caso não atenda, o indicador deve ser descartado);

- Critérios classificatórios: permitem a hierarquização dos indicadores, com suporte da técnica TOPSIS.

O Quadro 5.3 apresenta a proposta inicial de critérios eliminatórios e classificatórios, que deverão compor a matriz de avaliação quantitativa de indicadores de MA da regulamentação sobre rotulagem de alimentos alergênicos e derivados.

Essa proposta inicial foi validada durante o pré-teste com mestrandos do Programa de Pós-graduação em Metrologia, Qualidade e Inovação da PUC-Rio (ver Seção 5.2). 
Quadro 5.3 - Definição dos critérios eliminatórios e classificatórios de indicadores de MA

\begin{tabular}{|c|c|c|c|}
\hline \multicolumn{3}{|c|}{ Critérios } & $\begin{array}{l}\text { Justificativa do critério em relação à adequação } \\
\text { dos indicadores de MA }\end{array}$ \\
\hline \multirow{3}{*}{ 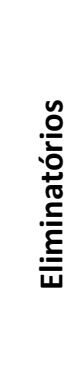 } & $\mathrm{C} 1$ & $\begin{array}{l}\text { Atendimento às } \\
\text { necessidades de } \\
\text { informação dos } \\
\text { interessados }\end{array}$ & $\begin{array}{l}\text { Deve atender às necessidades de informação dos } \\
\text { interessados, dada a efetiva implementação da } \\
\text { regulamentação. }\end{array}$ \\
\hline & $\mathrm{C} 2$ & $\begin{array}{l}\text { Rastreabilidade ao longo } \\
\text { do tempo }\end{array}$ & $\begin{array}{l}\text { Deve ser rastreável e dispor de disponíveis as } \\
\text { informações necessárias (documentos ou fontes } \\
\text { confiáveis). }\end{array}$ \\
\hline & $\mathrm{C} 3$ & $\begin{array}{l}\text { Representatividade (em } \\
\text { relação ao objetivo e } \\
\text { requisitos da norma) }\end{array}$ & $\begin{array}{l}\text { Qualidade na obtenção de resultados com } \\
\text { relação aos objetivos e aos requisitos da } \\
\text { regulamentação aplicável. }\end{array}$ \\
\hline \multirow{4}{*}{ 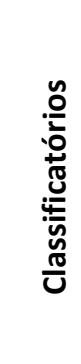 } & $\mathrm{C} 4$ & Mensurabilidade & $\begin{array}{l}\text { Deve estar disponível em qualquer momento } \\
\text { para que se possam adotar medidas preventivas } \\
\text { ou corretivas. }\end{array}$ \\
\hline & $\mathrm{C} 5$ & $\begin{array}{l}\text { Disponibilidade, quando } \\
\text { for necessário }\end{array}$ & $\begin{array}{l}\text { Deve contar com uma capacidade de mensuração } \\
\text { quando for necessário, além de uma ótima } \\
\text { precisão, sem ambiguidade. }\end{array}$ \\
\hline & $\mathrm{C6}$ & Objetividade & Imparcialidade nos resultados. \\
\hline & $\mathrm{C7}$ & Simplicidade & $\begin{array}{l}\text { Deve ser simples, claro e compreendido, para } \\
\text { facilitar a mensuração dos resultados obtidos. }\end{array}$ \\
\hline
\end{tabular}

Fonte: Elaboração própria.

\section{1 .5 \\ Proposição de indicadores iniciais}

O passo 5 consiste na proposição inicial dos indicadores, conforme recomendação do Ministério do Planejamento, Orçamento e Gestão (Brasil, 2010). Elaborou-se a lista de indicadores, com ajuda das seguintes fontes de informação:

- Proposta inicial da Resolução RDC no 26 sobre rotulagem de alimentos alergênicos (Anvisa, 2014), por acesso direto ao site da Anvisa e observação de seus anexos;

- Respostas à questão de interesse da Consulta Pública sobre MA da implementação da regulamentação de rotulagem de alimentos alergênicos, também no site da Anvisa;

- Requisitos de outras regulamentações aplicáveis - RDC no 259/2002 e Lei ${ }^{\circ}$ 10.674/2003;

- Experiências internacionais sobre rotulagem de alimentos alergênicos, descritos no capítulo 3 desta dissertação.

Nesta etapa, optou-se por desdobrar a matriz de avaliação quantitativa de indicadores de MA para a regulamentação de rotulagem de alimentos alergênicos e derivados em cinco matrizes associadas às categorias de requisitos legais da regulamentação aplicável (Quadro 5.1). 
A seguir, os Quadros 5.4 a 5.8 apresentam as propostas de indicadores que deverão compor as respectivas matrizes correspondentes às cinco categorias de requisitos legais da regulamentação em foco. Tais matrizes também foram validadas durante o pré-teste com mestrandos do Programa de Pós-graduação em Metrologia, Qualidade e Inovação da PUC-Rio (ver Seção 5.2).

Quadro 5.4 - Lista inicial de indicadores de MA para a categoria "Presença das informações obrigatórias gerais nos rótulos de alimentos embalados alergênicos e derivados"

\begin{tabular}{|c|c|}
\hline Referência & Indicadores/métricas \\
\hline Indicador 1 & Inadequação do rótulo por ausência da denominação de venda. \\
\hline Métrica 1.1 & $\begin{array}{l}\text { № de rótulos não conformes de alimentos embalados alergênicos e derivados devido à } \\
\text { ausência da denominação de venda do alimento (por categoria de alimento ou por área de } \\
\text { vigilância sanitária municipal) [s.u.]. }\end{array}$ \\
\hline Métrica 1.2 & $\begin{array}{l}\text { № de rótulos não conformes de alimentos embalados alergênicos e derivados devido à } \\
\text { ausência da denominação de venda do alimento/ total de rótulos de alimentos embalados } \\
\text { alergênicos e derivados (por categoria de alimento ou por área de vigilância sanitária } \\
\text { municipal) [\%]. }\end{array}$ \\
\hline Indicador 2 & Inadequação do rótulo por ausência da lista de ingredientes. \\
\hline Métrica 2.1 & $\begin{array}{l}\text { № de rótulos não conformes de alimentos embalados alergênicos e derivados devido à } \\
\text { ausência da lista de ingredientes (por categoria de alimento ou por área de vigilância sanitária } \\
\text { municipal) [s.u.]. }\end{array}$ \\
\hline Métrica 2.2 & $\begin{array}{l}\text { № de rótulos não conformes de alimentos embalados alergênicos e derivados devido à } \\
\text { ausência da lista de ingredientes / total de rótulos de alimentos embalados alergênicos e } \\
\text { derivados (por categoria de alimento ou por área de vigilância sanitária municipal) [\%]. }\end{array}$ \\
\hline Indicador 3 & Inadequação do rótulo por ausência de informação sobre conteúdos líquidos. \\
\hline Métrica 3.1 & $\begin{array}{l}\text { № de rótulos não conformes de alimentos embalados alergênicos e derivados devido à } \\
\text { ausência de informação sobre conteúdos líquidos (por categoria de alimento ou por área de } \\
\text { vigilância sanitária municipal) [s.u.]. }\end{array}$ \\
\hline Métrica 3.2 & $\begin{array}{l}\text { № de rótulos não conformes de alimentos embalados alergênicos e derivados devido à } \\
\text { ausência de informação sobre conteúdos líquidos / total de rótulos de alimentos embalados } \\
\text { alergênicos e derivados embalados (por categoria de alimento ou por área de vigilância } \\
\text { sanitária municipal) [\%]. }\end{array}$ \\
\hline Indicador 4 & Inadequação do rótulo por ausência de identificação da origem. \\
\hline Métrica 4.1 & $\begin{array}{l}\text { № de rótulos não conformes de alimentos embalados alergênicos e derivados devido à } \\
\text { ausência da identificação da origem (por categoria de alimento ou por área de vigilância } \\
\text { sanitária municipal) [s.u.]. }\end{array}$ \\
\hline Métrica 4.2 & $\begin{array}{l}\text { № de rótulos não conformes de alimentos embalados alergênicos e derivados devido à } \\
\text { ausência da identificação da origem / total de rótulos de alimentos embalados alergênicos e } \\
\text { derivados (por categoria de alimento ou por área de vigilância sanitária municipal) [\%.]. }\end{array}$ \\
\hline Indicador 5 & $\begin{array}{l}\text { Inadequação do rótulo por ausência do nome ou razão social e endereço do importador, no } \\
\text { caso de alimentos alergênicos e derivados embalados importados. }\end{array}$ \\
\hline Métrica 5.1 & $\begin{array}{l}\text { № de rótulos não conformes de alimentos embalados alergênicos e derivados importados } \\
\text { devido à ausência do nome ou razão social e endereço do importador (por categoria de } \\
\text { alimento ou por área de vigilância sanitária municipal) [s.u.]. }\end{array}$ \\
\hline Métrica 5.2 & $\begin{array}{l}\text { № de rótulos não conformes de alimentos embalados alergênicos e derivados importados } \\
\text { devido à ausência do nome ou razão social e endereço do importador / total de rótulos de } \\
\text { alimentos embalados alergênicos e derivados (por categoria de alimento ou por área de } \\
\text { vigilância sanitária municipal) [\%]. }\end{array}$ \\
\hline Indicador 6 & Inadequação do rótulo por ausência da identificação do lote. \\
\hline Métrica 6.1 & $\begin{array}{l}\text { № de rótulos não conformes de alimentos embalados alergênicos e derivados devido à } \\
\text { ausência da identificação do lote (por categoria de alimento ou por área de vigilância } \\
\text { sanitária municipal) [s.u.]. }\end{array}$ \\
\hline Métrica 6.2 & $\begin{array}{l}\text { № de rótulos não conformes de alimentos embalados alergênicos e derivados devido à } \\
\text { ausência da identificação do lote/ total de rótulos de alimentos embalados alergênicos e } \\
\text { derivados (por categoria de alimento ou por área de vigilância sanitária municipal) [\%]. }\end{array}$ \\
\hline
\end{tabular}

Continua... 
Quadro 5.4 - Lista inicial de indicadores de MA para a categoria "Presença das informações obrigatórias gerais nos rótulos de alimentos embalados alergênicos e derivados" (cont.)

\begin{tabular}{ll}
\hline Referência & Indicadores/métricas \\
\hline Indicador 7 & Inadequação do rótulo por ausência de informação sobre prazo de validade. \\
\hline Métrica 7.1 & $\begin{array}{l}\text { No de rótulos não conformes de alimentos embalados alergênicos e derivados devido à } \\
\text { ausência do prazo de validade (por categoria de alimento ou por área de vigilância sanitária } \\
\text { municipal) [s.u.]. }\end{array}$ \\
\hline Métrica 7.2 & $\begin{array}{l}\text { № de rótulos não conformes de alimentos embalados alergênicos e derivados devido à } \\
\text { ausência do prazo de validade / total de rótulos de alimentos embalados alergênicos e } \\
\text { derivados (por categoria de alimento ou por área de vigilância sanitária municipal) [\%]. }\end{array}$ \\
\hline Indicador 8 8 & $\begin{array}{l}\text { Inadequação do rótulo por ausência das instruções sobre preparo e uso do alimento, } \\
\text { quando necessário. }\end{array}$ \\
\hline Métrica 8.1 & $\begin{array}{l}\text { No de rótulos não conformes de alimentos embalados alergênicos e derivados devido à } \\
\text { ausência de instruções sobre preparo e uso do alimento, quando necessário (por categoria de } \\
\text { alimento ou por área de vigilância sanitária municipal) [s.u.]. }\end{array}$ \\
\hline Métrica 8.2 & $\begin{array}{l}\text { No de rótulos não conformes de alimentos embalados alergênicos e derivados devido à } \\
\text { ausência de instruções sobre preparo e uso do alimento, quando necessário / total de rótulos } \\
\text { de alimentos embalados alergênicos e derivados (por categoria de alimento ou por área de } \\
\text { vigilância sanitária municipal) [\%]. }\end{array}$ \\
\hline
\end{tabular}

Fonte: Elaboração própria.

Quadro 5.5 - Lista inicial de indicadores de MA para a categoria "Presença intencional de alimentos alergênicos e seus derivados"

\begin{tabular}{|c|c|}
\hline Referência & Indicadores/métricas \\
\hline Indicador 9 & $\begin{array}{l}\text { Inadequação do rótulo por ausência da declaração ‘Alérgicos': Contém [nomes comuns } \\
\text { dos alimentos que causam alergias alimentares]'. }\end{array}$ \\
\hline Métrica 9.1 & $\begin{array}{l}\text { № de rótulos não conformes de alimentos embalados alergênicos devido à ausência da } \\
\text { declaração 'Alérgicos: Contém [nomes comuns dos alimentos que causam alergias } \\
\text { alimentares]' (por categoria de alimento ou por área de vigilância sanitária municipal) } \\
\text { [s.u.]. }\end{array}$ \\
\hline Métrica 9.2 & $\begin{array}{l}\text { № de rótulos não conformes de alimentos embalados alergênicos devido à ausência da } \\
\text { declaração "Alérgicos: Contém [nomes comuns dos alimentos que causam alergias } \\
\text { alimentares]" / total de rótulos de alimentos alergênicos embalados [por categoria de } \\
\text { alimento ou por área de vigilância sanitária municipal]. }\end{array}$ \\
\hline Indicador 10 & $\begin{array}{l}\text { Inadequação do rótulo por ausência da declaração "Alérgicos: Contém derivados de } \\
\text { [nomes comuns dos alimentos que causam alergias alimentares]". }\end{array}$ \\
\hline Métrica 10.1 & $\begin{array}{l}\text { № de rótulos não conformes de alimentos embalados contendo derivados de alergênicos } \\
\text { devido à ausência da declaração "Alérgicos: Contém derivados de [nomes comuns dos } \\
\text { alimentos que causam alergias alimentares]" (por categoria de alimento ou por área de } \\
\text { vigilância sanitária municipal) [s.u.]. }\end{array}$ \\
\hline $\begin{array}{l}\text { Métrica } \\
10.2\end{array}$ & $\begin{array}{l}\text { № de rótulos não conformes de alimentos embalados contendo derivados de alergênicos } \\
\text { devido à ausência da declaração "Alérgicos: Contém derivados de [nomes comuns dos } \\
\text { alimentos que causam alergias alimentares]"/total de rótulos de alimentos embalados } \\
\text { contendo derivados de alergênicos (por categoria de alimento ou por área de vigilância } \\
\text { sanitária municipal) [\%]. }\end{array}$ \\
\hline $\begin{array}{l}\text { Indicador } \\
11\end{array}$ & $\begin{array}{l}\text { Inadequação do rótulo por ausência da declaração "Alérgicos: Contém [nomes } \\
\text { comuns dos alimentos que causam alergias alimentares] e derivados", conforme } \\
\text { o caso. }\end{array}$ \\
\hline $\begin{array}{l}\text { Métrica } \\
11.1\end{array}$ & $\begin{array}{l}\text { № de rótulos não conformes de alimentos embalados alergênicos e derivados devido à } \\
\text { ausência da declaração "Alérgicos: Contém [nomes comuns dos alimentos que causam } \\
\text { alergias alimentares] e derivados", conforme o caso (por categoria de alimento ou por área } \\
\text { de vigilância sanitária municipal) [s.u.]. }\end{array}$ \\
\hline $\begin{array}{l}\text { Métrica } \\
11.2\end{array}$ & $\begin{array}{l}\text { № de rótulos não conformes de alimentos embalados alergênicos e derivados devido à } \\
\text { ausência da declaração "Alérgicos: Contém [nomes comuns dos alimentos que causam } \\
\text { alergias alimentares] e derivados", conforme o caso/ total de rótulos alimentos embalados } \\
\text { alergênicos e derivados (por categoria de alimento ou por área de vigilância sanitária } \\
\text { municipal) [\%]. }\end{array}$ \\
\hline
\end{tabular}

Fonte: Elaboração própria. 
Quadro 5.6 - Lista inicial de indicadores de MA para a categoria "Possibilidade de contaminação cruzada com alimentos alergênicos e seus derivados"

\begin{tabular}{ll}
\hline Referência & Indicadores/métricas \\
\hline Indicador 12 & $\begin{array}{l}\text { Inadequação do rótulo por ausência da declaração 'Alérgicos: Pode Conter } \\
\text { [nomes comuns dos alimentos que causam alergias alimentares]' }\end{array}$ \\
\hline Métrica 12.1 & $\begin{array}{l}\text { No de rótulos não conformes de alimentos embalados alergênicos e derivados } \\
\text { devido à ausência da declaração 'Alérgicos: Pode Conter [nomes comuns dos } \\
\text { alimentos que causam alergias alimentares]' (por categoria de alimento ou por } \\
\text { área de vigilância sanitária municipal) [s.u.]. }\end{array}$ \\
\hline Métrica 12.2 & $\begin{array}{l}\text { № de rótulos não conformes de alimentos embalados alergênicos e derivados } \\
\text { devido à ausência da declaração 'Alérgicos: Pode Conter [nomes comuns dos } \\
\text { embalados alergênicos e derivados (por categoria de alimento ou por área de } \\
\text { vigilância sanitária municipal) [\%]. }\end{array}$ \\
\hline
\end{tabular}

Fonte: Elaboração própria.

Quadro 5.7 - Lista inicial de indicadores de MA para a categoria "Presença da declaração obrigatória 'Contém Glúten' ou 'Não Contém Glúten' nos rótulos de alimentos embalados"

\begin{tabular}{ll}
\hline Referência & Indicadores/métricas \\
\hline Indicador 13 13 & $\begin{array}{l}\text { Inadequação do rótulo por ausência da declaração 'Contém Glúten' ou 'Não } \\
\text { Contém Glúten', conforme o caso. }\end{array}$ \\
\hline Métrica 13.1 & $\begin{array}{l}\text { No de rótulos não conformes de alimentos embalados devido à ausência da } \\
\text { declaração 'Contém Glúten' ou 'Não Contém Glúten', conforme o caso (por } \\
\text { categoria de alimento ou por área de vigilância sanitária municipal) [s.u.]. }\end{array}$ \\
\hline Métrica 13.2 & $\begin{array}{l}\text { No de rótulos não conformes de alimentos embalados devido à ausência da } \\
\text { declaração 'Contém Glúten' ou 'Não Contém Glúten', conforme o caso/ total de } \\
\text { rótulos de alimentos embalados (por categoria de alimento ou por área de } \\
\text { vigilância sanitária municipal) [\%]. }\end{array}$ \\
\hline
\end{tabular}

Fonte: Elaboração própria.

Quadro 5.8 - Lista inicial de indicadores de MA para a categoria "Adequação da informação obrigatória nos rótulos de alimentos embalados alergênicos e derivados em relação aos parâmetros das regulamentações aplicáveis"

\begin{tabular}{ll}
\hline Referência & Indicadores/métricas \\
\hline Indicador 14 & $\begin{array}{l}\text { Inadequação de uma ou mais informações obrigatórias do rótulo em relação ao } \\
\text { parâmetro "expressão". }\end{array}$ \\
\hline Métrica 14.1 & $\begin{array}{l}\text { No de rótulos não conformes por inadequação de uma ou mais informações } \\
\text { obrigatórias em relação ao parâmetro “expressão" (por categoria de alimento ou } \\
\text { por área de vigilância sanitária municipal) [s.u.]. }\end{array}$ \\
\hline Métrica 14.2 & $\begin{array}{l}\text { Percentual de rótulos não conformes por inadequação de uma ou mais } \\
\text { informações obrigatórias em relação ao parâmetro "expressão"/ total de rótulos } \\
\text { de alimentos embalados alergênicos e derivados (por categoria de alimento ou } \\
\text { por área de vigilância sanitária municipal) [\%]. }\end{array}$ \\
\hline Indicador 15 15 & $\begin{array}{l}\text { Inadequação de uma ou mais informações obrigatórias do rótulo em relação ao } \\
\text { parâmetro "clareza". }\end{array}$ \\
\hline Métrica 15.1 & $\begin{array}{l}\text { No de rótulos não conformes por inadequação de uma ou mais informações } \\
\text { obrigatórias em relação ao parâmetro "clareza" (por categoria de alimento ou por } \\
\text { área de vigilância sanitária municipal) [s.u.]. }\end{array}$ \\
\hline Métrica 15.2 & $\begin{array}{l}\text { Percentual de rótulos não conformes por inadequação de uma ou mais } \\
\text { informações obrigatórias em relação ao parâmetro “clareza"/ total de rótulos de } \\
\text { alimentos embalados alergênicos e derivados (por categoria de alimento ou por } \\
\text { área de vigilância sanitária municipal) [\%]. }\end{array}$ \\
\hline
\end{tabular}

Continua... 
Quadro 5.8 - Lista inicial de indicadores de MA para a categoria "Adequação da informação obrigatória nos rótulos de alimentos embalados alergênicos e derivados em relação aos parâmetros das regulamentações aplicáveis" (cont.)

\begin{tabular}{|c|c|}
\hline Indicador 16 & $\begin{array}{l}\text { Inadequação de uma ou mais informações obrigatórias do rótulo em relação ao } \\
\text { parâmetro "visibilidade". }\end{array}$ \\
\hline Métrica 16.1 & $\begin{array}{l}\text { № de rótulos não conformes por inadequação de uma ou mais informações } \\
\text { obrigatórias em relação ao parâmetro "visibilidade" (por categoria de alimento ou } \\
\text { por área de vigilância sanitária municipal) [s.u.]. }\end{array}$ \\
\hline Métrica 16.2 & $\begin{array}{l}\text { Percentual de rótulos não conformes por inadequação de uma ou mais } \\
\text { informações obrigatórias em relação ao parâmetro "visibilidade"/ /total de } \\
\text { rótulos de alimentos embalados alergênicos e derivados (por categoria de } \\
\text { alimento ou por área de vigilância sanitária municipal) [\%]. }\end{array}$ \\
\hline Indicador 17 & $\begin{array}{l}\text { Inadequação de uma ou mais informações obrigatórias do rótulo em relação ao } \\
\text { parâmetro "tamanho da letra". }\end{array}$ \\
\hline Mét & $\begin{array}{l}\text { № de rótulos não conformes por inadequação de uma ou mais informações } \\
\text { obrigatórias em relação ao parâmetro "tamanho da letra" (por categoria de } \\
\text { alimento ou por área de vigilância sanitária municipal) [s.u.]. }\end{array}$ \\
\hline Mét & $\begin{array}{l}\text { Percentual de rótulos não conformes por inadequação de uma ou mais } \\
\text { informações obrigatórias em relação ao parâmetro "tamanho da letra"/total de } \\
\text { rótulos de alimentos embalados alergênicos e derivados (por categoria de } \\
\text { alimento ou por área de vigilância sanitária municipal) [\%]. }\end{array}$ \\
\hline Indic & $\begin{array}{l}\text { Inadequação de uma ou mais informações obrigatórias do rótulo em relação ao } \\
\text { parâmetro "contraste de cor". }\end{array}$ \\
\hline Métı & $\begin{array}{l}\text { № de rótulos não conformes por inadequação de uma ou mais informações } \\
\text { obrigatórias em relação ao parâmetro "contraste de cor" (por categoria de } \\
\text { alimento ou por área de vigilância sanitária municipal) [s.u.]. }\end{array}$ \\
\hline Métı & $\begin{array}{l}\text { Percentual de rótulos não conformes por inadequação de uma ou mais } \\
\text { informações obrigatórias em relação ao parâmetro "contraste de cor"/ total de } \\
\text { rótulos de alimentos embalados alergênicos e derivados (por categoria de } \\
\text { alimento ou por área de vigilância sanitária municipal) [\%]. }\end{array}$ \\
\hline Indicador 19 & $\begin{array}{l}\text { Inadequação de uma ou mais informações obrigatórias do rótulo em relação ao } \\
\text { parâmetro "realce". }\end{array}$ \\
\hline Mét & $\begin{array}{l}\text { № de rótulos não conformes por inadequação de uma ou mais informações } \\
\text { obrigatórias em relação ao parâmetro "realce" (por categoria de alimento ou por } \\
\text { área de vigilância sanitária municipal) [s.u.]. }\end{array}$ \\
\hline Métrica 19.2 & $\begin{array}{l}\text { Percentual de rótulos não conformes por inadequação de uma ou mais } \\
\text { informações obrigatórias em relação ao parâmetro "realce"/ total de rótulos de } \\
\text { alimentos embalados alergênicos e derivados (por categoria de alimento ou por } \\
\text { área de vigilância sanitária municipal) [\%]. }\end{array}$ \\
\hline
\end{tabular}

Fonte: Elaboração própria.

\section{2}

\section{Pré-teste da matriz de avaliação quantitativa de indicadores de MA}

Realizou-se o pré-teste das cinco "matrizes de avaliação quantitativa de indicadores de MA" com quatro mestrandos do Programa de Pós-graduação em Metrologia para Qualidade e Inovação da PUC-Rio (Pós-MQI). Os objetivos do pré-teste foram dimensionar o tempo necessário para preenchimento da matriz e melhorar a ferramenta com relação aos seguintes aspectos:

- Objetividade da mensagem introdutória;

- Clareza e precisão dos termos e das orientações;

- Estrutura da matriz e quantidade de itens a serem respondidos;

- Formato dos indicadores e métricas apresentadas. 
Todos os participantes do pré-teste consideraram o formato das matrizes adequado para aplicação posterior, mas sugeriram a retirada da indicação das respectivas métricas abaixo dos títulos dos indicadores propostos. Mencionaram um tempo médio de preenchimento de 60 minutos, partindo do pressuposto que os campos de critérios classificatórios seriam previamente preenchidos pela pesquisadora.

A definição dos pesos dos critérios classificatórios que integram as respectivas matrizes foi realizada logo após o pré-teste, com suporte do método AHP e com a participação de cinco especialistas, como descrito a seguir. O formato genérico das matrizes resultantes do pré-teste é apresentado no Apêndice 1.

\section{3}

\section{Aplicação do método AHP para definição dos pesos dos critérios classificatórios}

O método AHP, descrito no Anexo 1, foi o método de escolha para a definição de pesos dos quatro critérios classificatórios, a saber; (i) mensurabilidade; (ii) disponibilidade, quando for necessário; (iii) objetividade; e (iv) simplicidade de construção e entendimento. Esse método já havia sido adotado em pesquisa anterior do Programa Pós-MQI da PUC-Rio, referente à regulamentação de recolhimento de alimentos, gerando resultados confiáveis (Melo, 2015).

Tal escolha deveu-se aos seguintes fatores:

- Modelagem em hierarquias e as comparações pareadas facilitam o entendimento geral do problema;

- Aplicável a julgamentos subjetivos, que é o caso dos questionamentos a serem gerados para a definição dos pesos dos critérios classificatórios para escolha final dos indicadores de MA da implementação da regulamentação da rotulagem de alimentos alergênicos;

- Processo que pode ser documentado e repetido, caso haja necessidade de uma eventual inclusão de novos indicadores de MA;

- O uso do método é apropriado para grupos de decisão, como é o caso da aplicação futura pela Anvisa.

Para a aplicação do método AHP, foram consultados três especialistas da área de alimentos, um representante do grupo de consumidores com alergia a leite e derivados e dois mestrandos do Programa Pós-MQI, que não haviam participado 
do pré-teste das matrizes iniciais de avaliação dos indicadores de MA da regulamentação em foco. A Tabela 5.1 apresenta o perfil dos participantes desta etapa da pesquisa.

Tabela 5.1 - Perfil dos participantes da etapa de definição dos pesos dos critérios classificatórios

\begin{tabular}{ll}
\hline Perfil & Número \\
\hline Profissionais na indústria de alimentos & 1 \\
\hline Representantes da academia que atuam na área de alimentos & 2 \\
\hline Representante do grupo de consumidores com alergia a leite e derivados & 1 \\
\hline Mestrandos do Programa Pós-MQI da PUC-Rio & 2 \\
\hline Total & 6 \\
\hline
\end{tabular}

Fonte: Elaboração própria.

As comparações foram realizadas à luz dos focos principais da regulamentação em foco, que correspondem a cinco categorias de requisitos legais, definidas anteriormente. Partiu-se do pressuposto de que os pesos dos critérios classificatórios não sofreriam variação em função das diferentes categorias de requisitos.

A Tabela 5.2 mostra a matriz quadrada e recíproca, construída com os resultados das comparações pareadas dos critérios classificatórios, tendo em vista a escolha de indicadores para cada uma das categorias de requisitos legais da regulamentação em foco.

Os valores da diagonal da matriz serão sempre 1, pois refletem a comparação de um critério com ele mesmo. A leitura deve ser realizada a partir do critério indicado na linha em relação ao indicado na coluna. Por fim, o recíproco de cada elemento da matriz recebe o valor inverso da avaliação. Por exemplo, se C3 em relação a C4 é muito forte, recebendo pontuação 7, então $\mathrm{C} 4$ em relação a C3 receberá o valor inverso, 1/7. 
Tabela 5.2 - Comparação pareada dos critérios para classificação de indicadores de MA da regulamentação sobre rotulagem de alimentos alergênicos e derivados

\begin{tabular}{|c|c|c|c|c|}
\hline $\begin{array}{l}\text { Critérios para } \\
\text { classificação dos } \\
\text { indicadores de } \\
\text { MA }\end{array}$ & $\begin{array}{l}\text { C4: } \\
\text { Mensurabilidade }\end{array}$ & $\begin{array}{l}\text { C5: } \\
\text { Disponibilidade }\end{array}$ & $\begin{array}{l}\text { C6: } \\
\text { Objetividade }\end{array}$ & $\begin{array}{l}\text { C7: } \\
\text { Simplicidade }\end{array}$ \\
\hline $\begin{array}{l}\text { C4: } \\
\text { Mensurabilidade }\end{array}$ & 1 & 1 & 5 & 5 \\
\hline $\begin{array}{l}\text { C5: } \\
\text { Disponibilidade, } \\
\text { quando for } \\
\text { necessário }\end{array}$ & 1 & 1 & 3 & 3 \\
\hline C6: Objetividade & $1 / 5$ & $1 / 3$ & 1 & 1 \\
\hline $\begin{array}{l}\text { C7: Simplicidade } \\
\text { de construção e } \\
\text { entendimento }\end{array}$ & $1 / 5$ & $1 / 3$ & 1 & 1 \\
\hline
\end{tabular}

Fonte: Elaboração própria.

Com a matriz já preenchida (Tabela 5.2), utilizou-se o sistema computacional IPÊ, versão 1.0, para cálculo dos pesos dos critérios, visando a hierarquização dos indicadores de cada uma das categorias de requisitos legais da regulamentação em foco.

O sistema computacional IPÊ versão 1.0 é um sistema que possibilita o desenvolvimento e implementação de modelos de auxilio multicritério à decisão, fundamentados no Método de Análise Hierárquica (AHP) (Costa, 2004). Esse sistema foi desenvolvido pela Universidade Federal Fluminense (UFF), com o propósito de disseminar o uso do algoritmo do AHP proposto por Thomas L. Saaty (Costa, 2004).

A Tabela 5.3 mostra os pesos obtidos para cada um dos critérios classificatórios, juntamente com a "Razão de Consistência" (RC) das avaliações realizadas. De acordo com a descrição do método AHP (Anexo 1), os valores para a "Razão de Consistência" (RC) devem ser sempre menores que 0,1. 
Tabela 5.3 - Pesos dos critérios classificatórios e RC dos julgamentos pelos especialistas

\begin{tabular}{lll}
\hline Critério & Peso & RC \\
\hline C4: Mensurabilidade & 0,448 & 0,012 \\
\cline { 1 - 2 } C5: Disponibilidade, quando for necessário & 0,348 & Valor dentro do padrão \\
\cline { 1 - 2 } C6: Objetividade & 0,102 & $R C=0,1$ \\
\cline { 1 - 2 } C7: Simplicidade de construção e entendimento & 0,102 &
\end{tabular}

Fonte: Elaboração própria.

Os valores RC estão de acordo com o esperado, com valores menores a 0,1, indicando que as comparações entre critérios foram adequadas.

\section{4 \\ Aplicação da técnica TOPSIS para hierarquização final dos indicadores selecionados por categoria de requisitos legais}

Avaliou-se no passo 6 a existência de conflitos de escolha entre duas ou mais opções de indicadores, mediante uma análise quantitativa, com suporte da ferramenta TOPSIS, apresentada no capítulo anterior e descrita em detahe no Anexo 2. Para fins desta dissertação, considera-se a técnica TOPSIS como híbrida, pois foram utilizados pesos definidos anteriormente pelo método AHP.

Para a análise quantitativa, utilizaram-se cinco matrizes correspondentes às categorias de requisitos legais aplicáveis, conforme modelo lógico apresentado no Quadro 6. Essas matrizes são compostas pelos seguintes elementos:

- Linhas: contemplam os indicadores que foram propostos para MA da regulamentação em foco;

- Colunas: contém informações sobre o tipo do indicador (se chave, complementar ou específico); a natureza do critério de seleção (se o critério é eliminatório ou classificatório); e pesos (grau de importância) dos critérios classificatórios.

O preenchimento foi conduzido pelos cinco especialistas que partiparam da etapa anterior (ver Tabela 1), tendo como suporte a técnica TOPSIS, descrita no capítulo anterior. Os resultados da hierquização serão apresentados, respectivamente, nos itens 5.5.1 a 5.5.5, a seguir. Atendendo à recomendação do guia metodológico do Ministério do Planejamento, Orçamento e Gestão (Brasil, 2010), realizou-se ainda uma segunda análise, de natureza qualitativa. Os especialistas escolheram dentre os indicadores de posição superior, aqueles que melhor expressavam os resultados esperados com a implementação da regulamentação em foco. 


\subsection{1}

Indicadores referentes à categoria "Presença das informações obrigatórias nos rótulos de alimentos alergênicos e derivados"

Os participantes desta fase da pesquisa (Tabela 5.1) definiram o grau de atendimento dos indicadores propostos para esta categoria em relação aos critérios classificatórios, conforme Tabela 5.4.

Cabe destacar que a Tabela 5.4, ao ser submetida à etapa de julgamentos dos indicadores pelos especialistas, já contemplava os pesos de cada critério (ver Tabela 5.3).

Definidos os graus de atendimento dos indicadores propostos em relação aos critérios classificatórios, foi utilizado o algoritmo proposto por Krohling e Souza (2011) para cálculo das melhores alternativas, segundo a técnica TOPSIS.

As soluções ideais (positivas e negativas) e as distâncias euclidianas para cada indicador encontram-se apresentadas nas Tabelas 5.5 e 5.6, respectivamente. A partir das distâncias euclidianas, foram calculadas as proximidades relativas de

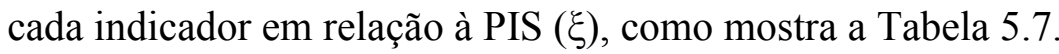




\begin{tabular}{|c|c|c|c|c|c|c|c|c|c|c|c|c|c|c|c|}
\hline \multirow{3}{*}{ 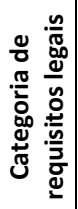 } & \multirow{3}{*}{ Indicador } & \multicolumn{3}{|c|}{ Tipo de indicador } & \multicolumn{11}{|c|}{ Natureza do indicador } \\
\hline & & \multirow[b]{2}{*}{ Chave } & \multirow[b]{2}{*}{ Complementar } & \multirow[b]{2}{*}{ Específico } & & & & \multicolumn{2}{|c|}{$\begin{array}{c}\text { C4: } \\
\text { Mensurabilidade }\end{array}$} & $\begin{array}{r}\mathrm{CS} \\
\text { Disponik }\end{array}$ & ilidade & $\begin{aligned} \mathrm{CC} & \\
\text { Objeti } & \end{aligned}$ & vidade & \multicolumn{2}{|c|}{$\begin{array}{c}\text { C7: } \\
\text { Simplicidade }\end{array}$} \\
\hline & & & & & C1 & C2 & C3 & Atende & Peso & \begin{tabular}{|l||} 
Atende \\
\end{tabular} & Peso & \begin{tabular}{|l|l} 
Atende \\
\end{tabular} & Peso & Atende & Peso \\
\hline \multirow{8}{*}{ 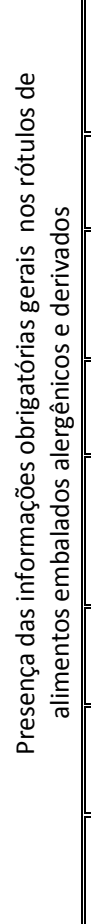 } & $\begin{array}{l}\text { Indicador 1: Inadequação do rótulo por } \\
\text { ausência da denominação de venda. }\end{array}$ & & $x$ & & 1 & 1 & 1 & 7 & 0,448 & 9 & 0,348 & 5 & 0,102 & 7 & 0,102 \\
\hline & $\begin{array}{l}\text { Indicador 2: Inadequação do rótulo por } \\
\text { ausência da lista de ingredientes. }\end{array}$ & $\mathrm{x}$ & & & 1 & 1 & 1 & 9 & 0,448 & 9 & 0,348 & 9 & 0,102 & 7 & 0,102 \\
\hline & $\begin{array}{l}\text { Indicador 3: Inadequação do rótulo por } \\
\text { ausência de informação sobre conteúdos } \\
\text { líquidos. }\end{array}$ & $\mathrm{x}$ & & & 1 & 1 & 1 & 9 & 0,448 & 9 & 0,348 & 9 & 0,102 & 7 & 0,102 \\
\hline & $\begin{array}{l}\text { Indicador 4: Inadequação do rótulo por } \\
\text { ausência de identificação da origem. }\end{array}$ & $x$ & & & 1 & 1 & 1 & 9 & 0,448 & 9 & 0,348 & 7 & 0,102 & 7 & 0,102 \\
\hline & \begin{tabular}{|l} 
Indicador 5: Inadequação do rótulo por \\
ausência do nome ou razão social e \\
endereço do importador, no caso de \\
alimentos importados.
\end{tabular} & & $\mathrm{x}$ & & 1 & 1 & 1 & 5 & 0,448 & 5 & 0,348 & 3 & 0,102 & 3 & 0,102 \\
\hline & $\begin{array}{l}\text { Indicador 6: Inadequação do rótulo por } \\
\text { ausência da identificação do lote. }\end{array}$ & $x$ & & & 1 & 1 & 1 & 9 & 0,448 & 7 & 0,348 & 7 & 0,102 & 7 & 0,102 \\
\hline & $\begin{array}{l}\text { Indicador 7: Inadequação do rótulo por } \\
\text { ausência de informação sobre o prazo de } \\
\text { validade. }\end{array}$ & & $\mathrm{x}$ & & 1 & 1 & 1 & 9 & 0,448 & 7 & 0,348 & 5 & 0,102 & 7 & 0,102 \\
\hline & $\begin{array}{l}\text { Indicador 8: Inadequação do rótulo por } \\
\text { ausência das instruções sobre preparo e } \\
\text { uso do alimento, quando necessário. }\end{array}$ & & $\mathrm{x}$ & & 1 & 1 & 1 & 5 & 0,448 & 7 & 0,348 & 5 & 0,102 & 3 & 0,102 \\
\hline
\end{tabular}


Tabela 5.5 - Soluções ideais PIS e NIS para os critérios classificatórios: categoria "Presença das informações obrigatórias gerais nos rótulos de alimentos embalados alergênicos e derivados"

\begin{tabular}{lll}
\hline Critério & PIS & NIS \\
\hline C4 - Mensurabilidade & 1 & 0,56 \\
\hline C5 - Disponibilidade & 1 & 0,56 \\
\hline C6 - Objetividade & 1 & 0,33 \\
\hline C7 - Simplicidade & 1 & 0,43
\end{tabular}

Legenda: PIS - solução ideal positiva; NIS- solução ideal negativa.

Fonte: Elaboração própria.

Tabela 5.6 - Distâncias euclidianas (positivas e negativas) dos indicadores para a categoria "Presença das informações obrigatórias gerais nos rótulos de alimentos embalados alergênicos e derivados"

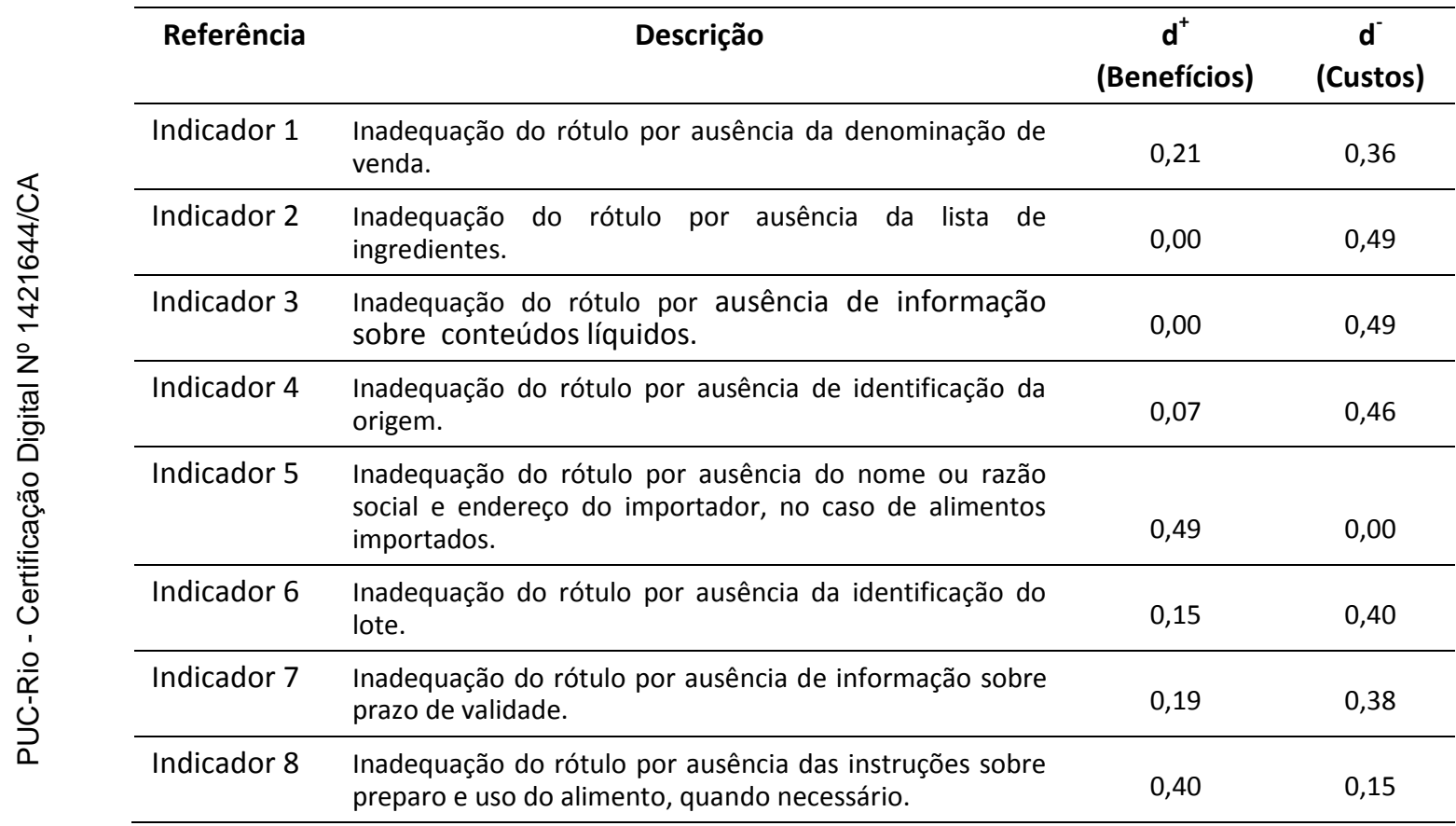

Fonte: Elaboração própria.

A partir das distâncias euclidianas, foram calculadas as proximidades relativas de cada indicador em relação à PIS $(\xi)$, que se encontram na Tabela 5.7. 
Tabela 5.7 - Proximidades relativas dos indicadores em relação à PIS para a categoria "Presença das informações obrigatórias nos rótulos de alimentos embalados, incluindo alergênicos e derivados"

\begin{tabular}{|c|c|c|}
\hline Referência & Indicador & $\begin{array}{l}\text { Proximidade } \\
\text { relativa } \xi\end{array}$ \\
\hline Indicador 1 & Inadequação do rótulo por ausência da denominação de venda. & 0,64 \\
\hline Indicador 2 & Inadequação do rótulo por ausência da lista de ingredientes. & 1,00 \\
\hline Indicador 3 & $\begin{array}{l}\text { Inadequação do rótulo por ausência de informação sobre } \\
\text { conteúdos líquidos. }\end{array}$ & 1,00 \\
\hline Indicador 4 & Inadequação do rótulo por ausência de identificação da origem. & 0,87 \\
\hline Indicador 5 & $\begin{array}{l}\text { Inadequação do rótulo por ausência do nome ou razão social e } \\
\text { endereço do importador, no caso de alimentos importados. }\end{array}$ & 0,00 \\
\hline Indicador 6 & Inadequação do rótulo por ausência da identificação do lote. & 0,73 \\
\hline Indicador 7 & $\begin{array}{l}\text { Inadequação do rótulo por ausência de informação sobre prazo de } \\
\text { validade. }\end{array}$ & 0,66 \\
\hline Indicador 8 & $\begin{array}{l}\text { Inadequação do rótulo por ausência das instruções sobre preparo e uso } \\
\text { do alimento, quando necessário. }\end{array}$ & 0,27 \\
\hline
\end{tabular}

Fonte: Elaboração própria.

A Tabela 5.8 mostra os resultados da hierarquização dos indicadores desta categoria, com o suporte da técnica TOPSIS.

Tabela 5.8 - Hierarquização dos indicadores para a categoria "Presença das informações obrigatórias gerais nos rótulos de alimentos embalados alergênicos e derivados"

\begin{tabular}{|c|c|c|}
\hline Posição & Referência & Indicador \\
\hline 10 & Indicador 2 & Inadequação do rótulo por ausência da lista de ingredientes. \\
\hline 1 은 & Indicador 3 & $\begin{array}{l}\text { Inadequação do rótulo por ausência de informação sobre } \\
\text { conteúdos líquidos. }\end{array}$ \\
\hline 20 & Indicador 4 & Inadequação do rótulo por ausência de identificação da origem. \\
\hline 30 & Indicador 6 & Inadequação do rótulo por ausência da identificação do lote. \\
\hline 4은 & Indicador 7 & $\begin{array}{l}\text { Inadequação do rótulo por ausência de informação sobre prazo de } \\
\text { validade. }\end{array}$ \\
\hline 50 & Indicador 1 & Inadequação do rótulo por ausência da denominação de venda. \\
\hline 6o & Indicador 8 & $\begin{array}{l}\text { Inadequação do rótulo por ausência das instruções sobre preparo e } \\
\text { uso do alimento, quando necessário. }\end{array}$ \\
\hline 7음 & Indicador 5 & $\begin{array}{l}\text { Inadequação do rótulo por ausência do nome ou razão social e } \\
\text { endereço do importador, no caso de alimentos importados. }\end{array}$ \\
\hline
\end{tabular}

Fonte: Elaboração própria. 


\section{4 .2}

Indicadores referentes à categoria "Presença intencional de alimentos alergênicos e derivados"

Realizou-se com os especialistas o mesmo procedimento descrito no item anterior, definindo-se o grau de atendimento dos indicadores propostos desta categoria em relação aos critérios classificatórios.

Neste caso, não foi necessário aplicar a técnica TOPSIS para hierarquização dos indicadores propostos, uma vez que todos receberam graus de atendimento máximo aos quarto critérios classificatórios. São eles: (i) indicador 9 inadequação do rótulo por ausência da declaração "Alérgicos: Contém [nomes comuns dos alimentos que causam alergias alimentares]; (ii) indicador 10 inadequação do rótulo por ausência da declaração "Alérgicos: Contém derivados de [nomes comuns dos alimentos que causam alergias alimentares]"; e (iii) indicador 11 - inadequação do rótulo por ausência da declaração "Alérgicos: Contém [nomes comuns dos alimentos que causam alergias alimentares] e derivados", conforme o caso.

\section{4 .3}

\section{Indicadores referentes à categoria "Possibilidade de contaminação cruzada com alimentos alergênicos e seus derivados"}

Para esta categoria, não houve necessidade de se aplicar a técnica TOPSIS, uma vez que foi proposto somente o indicador 12 - Inadequação do rótulo por ausência da declaração de 'Alérgicos: Pode Conter (nomes comuns dos alimentos que causam alergias alimentares)'.

\section{4 .4}

Indicadores referentes à categoria "Presença da declaração obrigatória 'Contém Glúten' ou 'Não Contém Glúten' nos rótulos de alimentos embalados"

Também neste caso, não houve necessidade de se aplicar a técnica TOPSIS, pois foi proposto somente o indicador 13 - Inadequação do rótulo por ausência da declaração de “Contém Glúten” ou “Não Contém Glúten”, conforme o caso. 


\subsection{5}

Indicadores referentes à categoria "Adequação da informação obrigatória nos rótulos de alimentos alergênicos e derivados em relação aos parâmetros das regulamentações aplicáveis"

Realizou-se o mesmo procedimento descrito no item 5.4.1, definindo-se o grau de atendimento dos indicadores propostos desta categoria em relação aos critérios classificatórios (Tabela 5.9).

As soluções ideais (positivas e negativas) e as distâncias euclidianas para cada indicador encontram-se apresentadas nas Tabelas 5.10 e 5.11, respectivamente. A partir das distâncias euclidianas, foram calculadas as proximidades relativas de cada indicador em relação à PIS $(\xi)$, como mostra a Tabela 5.12. Finalmente, a Tabela 5.13 apresenta os resultados da hierarquização dos indicadores desta categoria. 


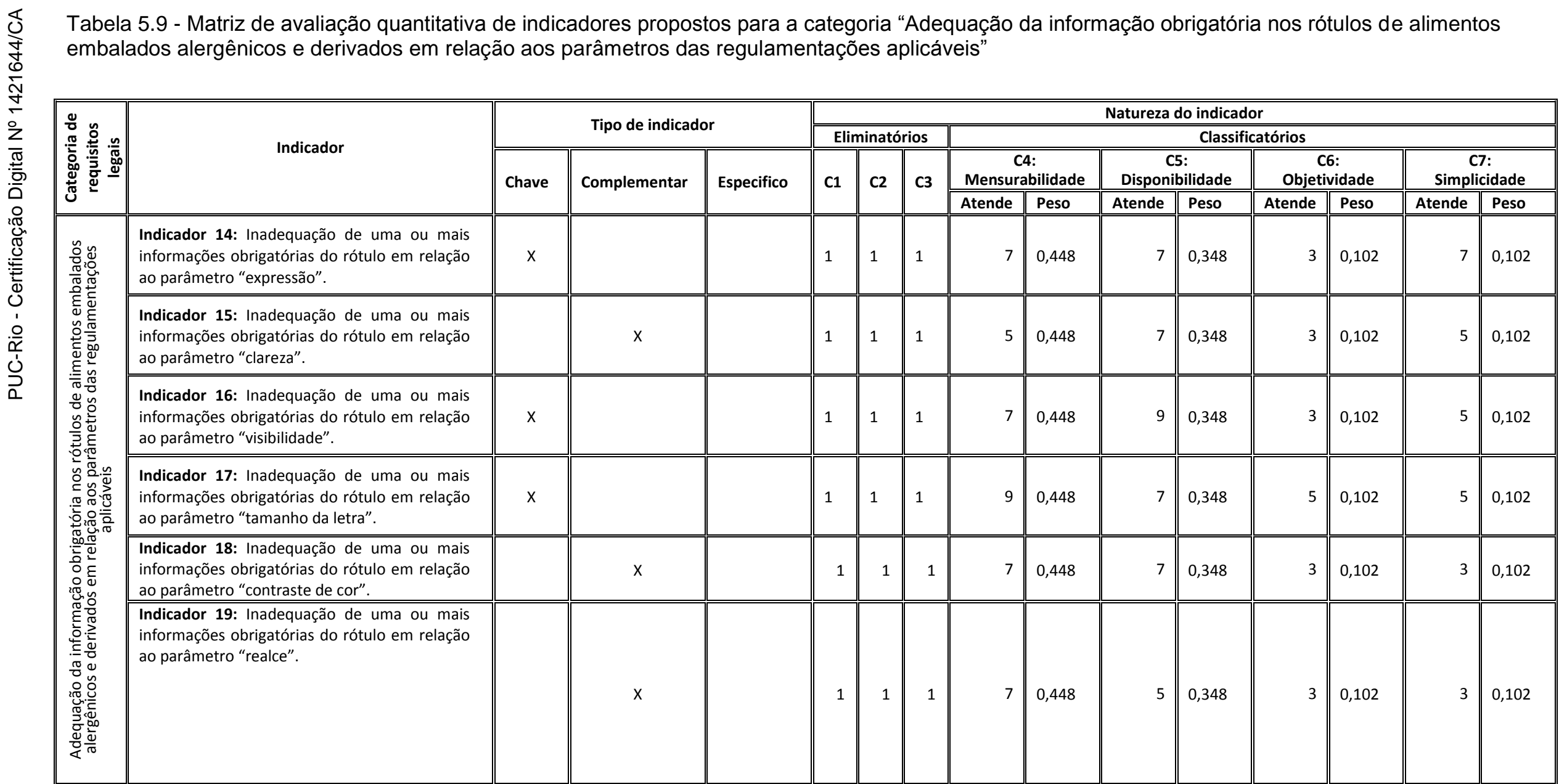


Tabela 5.10 - Soluções ideais PIS e NIS para os critérios classificatórios: categoria "Adequação das informações obrigatórias do rótulo em relação aos parâmetros das regulamentações aplicáveis"

\begin{tabular}{lll}
\hline Critério & PIS & NIS \\
\hline C4 - Mensurabilidade & 1 & 0,56 \\
\hline C5 - Disponibilidade & 1 & 0,56 \\
\hline C6 - Objetividade & 1 & 0,60 \\
\hline C7 - Simplicidade & 1 & 0,43 \\
\hline
\end{tabular}

Legenda: PIS - solução ideal positiva; NIS- solução ideal negativa.

Fonte: Elaboração própria.

Tabela 5.11 - Distâncias euclidianas (positivas e negativas) dos indicadores propostos para a categoria "Adequação das informações obrigatórias do rótulo em relação aos parâmetros das regulamentações aplicáveis"

\begin{tabular}{llcc}
\hline Referência & Indicador & $\begin{array}{l}\mathbf{d}^{+} \\
\text {(Benefícios) }\end{array}$ & $\begin{array}{c}\mathbf{d}^{-} \\
\text {(Custos) }\end{array}$ \\
\hline Indicador 14 & $\begin{array}{l}\text { Inadequação de uma ou mais informações } \\
\text { obrigatórias do rótulo em relação ao parâmetro } \\
\text { "expressão". }\end{array}$ & 0,24 & 0,27 \\
\hline Indicador 15 & $\begin{array}{l}\text { Inadequação de uma ou mais informações } \\
\text { obrigatórias do rótulo em relação ao parâmetro } \\
\text { "clareza". }\end{array}$ & 0,36 & 0,16 \\
\hline Indicador 16 & $\begin{array}{l}\text { Inadequação de uma ou mais informações } \\
\text { obrigatórias do rótulo em relação ao parâmetro } \\
\text { "visibilidade". }\end{array}$ & 0,22 & 0,31 \\
\hline Indicador 17 & $\begin{array}{l}\text { Inadequação de uma ou mais informações } \\
\text { obrigatórias do rótulo em relação ao parâmetro } \\
\text { "tamanho da letra". }\end{array}$ & 0,16 & 0,36 \\
\hline Indicador 18 & $\begin{array}{l}\text { Inadequação de uma ou mais informações } \\
\text { obrigatórias do rótulo em relação ao parâmetro } \\
\text { "contraste de cor". }\end{array}$ & 0,30 & 0,20 \\
\hline Indicador 19 & $\begin{array}{l}\text { Inadequação de uma ou mais informações } \\
\text { obrigatórias do rótulo em relação ao parâmetro } \\
\text { "realce". }\end{array}$ & 0,37 & 0,15 \\
\hline
\end{tabular}

Fonte: Elaboração própria.

Tabela 5.12 - Proximidades relativas dos indicadores em relação à PIS para a categoria "Adequação das informações obrigatórias do rótulo em relação aos parâmetros das regulamentações aplicáveis"

\begin{tabular}{|c|c|c|}
\hline Referência & Indicador & $\begin{array}{l}\text { Proximidade } \\
\text { Relativa } \xi\end{array}$ \\
\hline Indicador 14 & $\begin{array}{l}\text { Inadequação de uma ou mais informações obrigatórias do rótulo em } \\
\text { relação ao parâmetro "expressão". }\end{array}$ & 0,53 \\
\hline Indicador 15 & $\begin{array}{l}\text { Inadequação de uma ou mais informações obrigatórias do rótulo em } \\
\text { relação ao parâmetro "clareza". }\end{array}$ & 0,31 \\
\hline Indicador 16 & $\begin{array}{l}\text { Inadequação de uma ou mais informações obrigatórias do rótulo em } \\
\text { relação ao parâmetro "visibilidade". }\end{array}$ & 0,59 \\
\hline Indicador 17 & $\begin{array}{l}\text { Inadequação de uma ou mais informações obrigatórias do rótulo em } \\
\text { relação ao parâmetro "tamanho da letra". }\end{array}$ & 0,69 \\
\hline Indicador 18 & $\begin{array}{l}\text { Inadequação de uma ou mais informações obrigatórias do rótulo em } \\
\text { relação ao parâmetro "contraste de cor". }\end{array}$ & 0,40 \\
\hline Indicador 19 & $\begin{array}{l}\text { Inadequação de uma ou mais informações obrigatórias do rótulo em } \\
\text { relação ao parâmetro "realce". }\end{array}$ & 0,28 \\
\hline
\end{tabular}

Fonte: Elaboração própria. 
A Tabela 5.13 apresenta os resultados da hierarquização dos indicadores desta categoria, com o suporte da técnica TOPSIS.

Tabela 5.13 - Hierarquização dos indicadores propostos para a categoria "Adequação das informações obrigatórias do rótulo em relação aos parâmetros das regulamentações aplicáveis"

\begin{tabular}{|c|c|c|}
\hline Posição & Referência & Indicador \\
\hline 10 & Indicador 17 & $\begin{array}{l}17 \text { - Inadequação de uma ou mais informações } \\
\text { obrigatórias do rótulo em relação ao parâmetro } \\
\text { "tamanho da letra". }\end{array}$ \\
\hline 20 & Indicador 16 & $\begin{array}{l}16 \text { - Inadequação de uma ou mais informações } \\
\text { obrigatórias do rótulo em relação ao parâmetro } \\
\text { "visibilidade". }\end{array}$ \\
\hline 30 & Indicador 14 & $\begin{array}{l}14 \text { - Inadequação de uma ou mais informações } \\
\text { obrigatórias do rótulo em relação ao parâmetro } \\
\text { "expressão". }\end{array}$ \\
\hline 40 & Indicador 18 & $\begin{array}{l}18 \text { - Inadequação de uma ou mais informações } \\
\text { obrigatórias do rótulo em relação ao parâmetro } \\
\text { "contraste de cor". }\end{array}$ \\
\hline 50 & Indicador 15 & $\begin{array}{l}15 \text { - Inadequação de uma ou mais informações } \\
\text { obrigatórias do rótulo em relação ao parâmetro } \\
\text { "clareza". }\end{array}$ \\
\hline 60 & Indicador 19 & $\begin{array}{l}19 \text { - Inadequação de uma ou mais informações } \\
\text { obrigatórias do rótulo em relação ao parâmetro } \\
\text { "realce". }\end{array}$ \\
\hline
\end{tabular}

Fonte: Elaboração própria.

\section{5 Resultado final da hierarquização dos indicadores de MA para a regulamentação em foco}

O Quadro 5.10 sintetiza o resultado final da simulação feita com três especialistas da área de alimentos, dois mestrandos do Programa Pós-MQI da PUC-Rio e um representante do grupo de consumidores com alergia a leite e derivados. Essa simulação teve por objetivo demonstrar a aplicabilidade e facilidade de uso da ferramenta de seleção e hieraquização de indicadores de MA para a regulamentação em foco. Os procedimentos adotados poderão ser replicados no âmbito da Anvisa, tanto para a avaliação quantitativa de indicadores de MA para esta regulamentação, quanto para indicadores de outras regulamentações já implementadas.

Cabe destacar que nenhum indicador da proposta inicial foi excluído pelos participantes desta simulação. 
Quadro 5.9 - Lista geral dos indicadores de MA para a regulamentação em foco, hierarquizados por categoria de requisitos legais

\begin{tabular}{|c|c|c|}
\hline $\begin{array}{l}\text { Categoria de requisitos } \\
\text { legais }\end{array}$ & Indicador & Posição \\
\hline \multirow{8}{*}{$\begin{array}{l}\text { Presença das informações } \\
\text { obrigatórias gerais nos } \\
\text { rótulos de alimentos } \\
\text { embalados alergênicos e } \\
\text { derivados }\end{array}$} & $\begin{array}{l}2 \text { - Inadequação do rótulo por ausência da lista de } \\
\text { ingredientes. }\end{array}$ & 10 \\
\hline & $\begin{array}{l}3 \text { - Inadequação do rótulo por ausência de informação } \\
\text { sobre conteúdos líquidos. }\end{array}$ & 10 \\
\hline & $\begin{array}{l}4 \text { - Inadequação do rótulo por ausência de identificação da } \\
\text { origem. }\end{array}$ & 20 \\
\hline & $\begin{array}{l}6 \text { - Inadequação do rótulo por ausência da identificação do } \\
\text { lote. }\end{array}$ & 30 \\
\hline & $\begin{array}{l}7 \text { - Inadequação do rótulo por ausência de informação } \\
\text { sobre prazo de validade. }\end{array}$ & 40 \\
\hline & $\begin{array}{l}1 \text { - Inadequação do rótulo por ausência da denominação } \\
\text { de venda. }\end{array}$ & 50 \\
\hline & $\begin{array}{l}8 \text { - Inadequação do rótulo por ausência das instruções } \\
\text { sobre preparo e uso do alimento, quando necessário. }\end{array}$ & 60 \\
\hline & $\begin{array}{l}5 \text { - Inadequação do rótulo por ausência do nome ou razão } \\
\text { social e endereço do importador, no caso de alimentos } \\
\text { importados. }\end{array}$ & 70 \\
\hline \multirow[t]{3}{*}{$\begin{array}{l}\text { Presença intencional de } \\
\text { alimentos alergênicos e } \\
\text { seus derivados. }\end{array}$} & $\begin{array}{l}10 \text { - Inadequação do rótulo por ausência da declaração } \\
\text { "Alérgicos: Contém derivados de [nomes comuns dos } \\
\text { alimentos que causam alergias alimentares]" }\end{array}$ & 10 \\
\hline & $\begin{array}{l}9 \text { - Inadequação do rótulo por ausência da declaração } \\
\text { "Alérgicos: Contém [nomes comuns dos alimentos que } \\
\text { causam alergias alimentares]" }\end{array}$ & 10 \\
\hline & $\begin{array}{l}11 \text { - Inadequação do rótulo por ausência da declaração de } \\
\text { "Alérgicos: Contém [nomes comuns dos alimentos que } \\
\text { causam alergias alimentares] e derivados, conforme o } \\
\text { caso". }\end{array}$ & 10 \\
\hline $\begin{array}{l}\text { Possibilidade de } \\
\text { contaminação cruzada com } \\
\text { alimentos alergênicos e } \\
\text { seus derivados. }\end{array}$ & $\begin{array}{l}12 \text { - Inadequação do rótulo por ausência da declaração de } \\
\text { 'Alérgicos: Pode Conter (nomes comuns dos alimentos que } \\
\text { causam alergias alimentares)'. }\end{array}$ & 10 \\
\hline $\begin{array}{l}\text { Presença da declaração } \\
\text { obrigatória "Contém } \\
\text { Glúten" ou “Não Contém } \\
\text { Glúten" nos rótulos de } \\
\text { alimentos embalados. } \\
\end{array}$ & $\begin{array}{l}13 \text { - Inadequação do rótulo por ausência da declaração de } \\
\text { "Contém Glúten" ou "Não Contém Glúten", conforme o } \\
\text { caso. }\end{array}$ & 10 \\
\hline \multirow{6}{*}{$\begin{array}{l}\text { Adequação da informação } \\
\text { obrigatória nos rótulos de } \\
\text { alimentos embalados } \\
\text { alergênicos e derivados em } \\
\text { relação aos parâmetros das } \\
\text { regulamentações aplicáveis }\end{array}$} & $\begin{array}{l}17 \text { - Inadequação de uma ou mais informações } \\
\text { obrigatórias do rótulo em relação ao parâmetro } \\
\text { "tamanho da letra". }\end{array}$ & 10 \\
\hline & $\begin{array}{l}16 \text { - Inadequação de uma ou mais informações } \\
\text { obrigatórias do rótulo em relação ao parâmetro } \\
\text { "visibilidade". }\end{array}$ & 20 \\
\hline & $\begin{array}{l}14 \text { - Inadequação de uma ou mais informações } \\
\text { obrigatórias do rótulo em relação ao parâmetro } \\
\text { "expressão". }\end{array}$ & 3응 \\
\hline & $\begin{array}{l}18 \text { - Inadequação de uma ou mais informações } \\
\text { obrigatórias do rótulo em relação ao parâmetro } \\
\text { "contraste de cor". }\end{array}$ & 40 \\
\hline & $\begin{array}{l}15 \text { - Inadequação de uma ou mais informações } \\
\text { obrigatórias do rótulo em relação ao parâmetro } \\
\text { "clareza". }\end{array}$ & 5은 \\
\hline & $\begin{array}{l}19 \text { - Inadequação de uma ou mais informações } \\
\text { obrigatórias do rótulo em relação ao parâmetro } \\
\text { "realce". }\end{array}$ & 60 \\
\hline
\end{tabular}

Fonte: Elaboração própria. 


\section{6}

\section{Considerações finais sobre o capítulo}

Pelos resultados apresentados neste capítulo, pode-se demonstrar a aplicabilidade da ferramenta para definição de indicadores e respectivas métricas desenvolvida para a regulamentação sobre rotulagem de alimentos alergênicos e derivados no Brasil.

Com o suporte da abordagem metodológica proposta no documento "Indicadores de Programas: Guia Metodológico" (Brasil, 2010), foi possível desenvolver uma matriz inicial de avaliação quantitativa de indicadores, que, por sua vez, foi submetida a um pré-teste junto a mestrandos do Programa Pós-MQI da PUC-Rio. Todos os participantes do pré-teste consideraram o formato e os conteúdos da matriz adequado para aplicação posterior, sugerindo apenas a retirada das métricas.

Optou-se pela abordagem de categorização de requisitos legais para o desenho da referida matriz. Desse modo, foi possível identificar com objetividade os aspectos da regulamentação proposta pela Anvisa que deveriam ser alvo de monitoramento e avaliação, refletindo-se diretamente na proposição posterior de 19 indicadores e respectivas métricas (Quadros 5.4 a 5.8).

Buscando contribuir para o refinamento e melhoria contínua da abordagem metodológica proposta pelo Ministério do Planejamento, Orçamento e Gestão, adotaram-se dois métodos multicritério de apoio à decisão, a saber: método AHP para definição dos pesos dos critérios classificatórios e a técnica TOPSIS para a hierarquização final dos indicadores selecionados (por categoria de requisitos legais). Assim, o resultado final da pesquisa consiste de uma lista 19 indicadores, hierarquizados pelo grau de atendimento aos critérios classificatórios, por categoria de requisitos legais (Quadro 5.10). 


\section{6 \\ Conclusões e recomendações}

A presente pesquisa contribuiu para o avanço do conhecimento sobre ferramentas de monitoramento e avaliação (MA) como instrumentos de gestão pública, focalizando uma aplicação referente à regulamentação no Brasil sobre rotulagem de alimentos que causam alergias e seus derivados. Nesse sentido, uma ferramenta de avaliação quantitativa de indicadores de MA foi desenvolvida especificamente para responder a uma das questões da Consulta Pública 29/2014 da Anvisa sobre a proposta de Resolução para a regulamentação em foco.

Os resultados obtidos ao longo da pesquisa aqui relatada permitiram que o objetivo geral da dissertação fosse alcançado. Foi possível, com uso da matriz quantitativa de indicadores e de dois métodos multicritério de apoio à decisão, propor indicadores e respectivas métricas para o monitoramento e avaliação da regulamentação abordada.

Os marcos conceituais e metodológicos discutidos nos capítulos 2 a 4 fundamentaram o desenvolvimento e aplicação deste ferramental, contribuindo de forma significativa para que os objetivos específicos da dissertação fossem alcançados.

Pelos aspectos descritos e resultados gerados na fase aplicada da pesquisa, considera-se que eles propiciarão ao órgão regulador, bem como aos diversos atores envolvidos na implementação dessa regulamentação, o ferramental adequado para o monitoramento dos procedimentos e avaliação de seus resultados. Quando aplicados pela Anvisa em toda sua abrangência, poderá ser considerada como uma inovação organizacional.

Com relação ao primeiro objetivo específico - "Discutir a importância da regulamentação de rotulagem de alimentos alergênicos e derivados para a segurança de alimentos", foi possível contextualizar a experiência recente do Brasil relacionada à essa regulamentação, desde os antecedentes até a proposta de Resolução $n^{\circ}$ 26/2015, que estabeleceu as regras para as declarações de rotulagem relativas à: (i) presença intencional de alimentos alergênicos e seus derivados; (ii) 
possibilidade de contaminação cruzada com alimentos alergênicos ou seus derivados; e (iii) ausência de alimentos alergênicos e seus derivados.

$\mathrm{O}$ segundo e o terceiro objetivos - "Identificar os aspectos da regulamentação sobre rotulagem de alimentos alergênicos e derivados que necessitam de monitoramento e avaliação após sua implementação" e "Elaborar a matriz inicial de indicadores de MA da regulamentação em foco" - foram plenamente atingidos, mediante a construção do modelo lógico da regulamentação baseada na metodologia desenvolvida pelo Ministério de Planejamento, Orçamento e Gestão (Brasil, 2010). A análise do objetivo e dos resultados esperados da regulamentação propiciou a identificação objetiva das categorias de requisitos legais que deveriam ser objeto de MA, conforme solicitação pela Anvisa na Consulta Pública 29/2014.

Com suporte de métodos multicritério de apoio à decisão, particularmente do método AHP e da técnica TOPSIS, foi possível desenvolver e demonstrar a ferramenta para avaliação quantitativa dos indicadores propostos inicialmente, por simulação que contou com a participação de três especialistas da área de alimentos, dois mestrandos do Programa Pós-MQI da PUC-Rio e um representante do grupo de consumidores com alergia a leite e derivados. Atingiuse, assim, o quarto objetivo específico - "Desenvolver a ferramenta de seleção e classificação de indicadores de MA, com suporte de métodos de apoio à decisão multicritério".

Finalmente, como resultado da simulação da avaliação quantitativa e qualitativa dos indicadores candidatos, chegou-se a um conjunto de 19 indicadores de MA, hierarquizados pelo método TOPSIS por categoria de requisitos legais aplicáveis (Seção 5.5 do capítulo 5). Assim, o quinto objetivo específico "Propor indicadores e métricas para o monitoramento e avaliação da regulamentação sobre rotulagem de alimentos alergênicos e derivados no Brasil, após sua implementação".

Para fins de integração dos indicadores aqui propostos a uma sistemática de monitoramento e avaliação da regulamentação em foco, pela Anvisa, recomendase:

- Validar os resultados da etapa 6 com representantes da Visa-RJ, pela facilidade da localização geográfica no município do Rio de Janeiro; 
- Realizar as etapas 7 e 8 da metodologia de construção de indicadores, que vem sendo adotada pelo Ministério do Planejamento, Orçamento e Gestão, ou seja validar no âmbito da Anvisa e cadastrar os indicadores em sistemas de informações gerenciais da Agência.

Para trabalhos futuros de desdobramento da pesquisa e aprofundamento dos resultados, propõem-se:

- Aplicar as ferramentas de modelo lógico e de seleção e hierarquização de indicadores de MA no contexto do Programa de Controle de Alergênicos, que é um programa para a identificação e o controle dos principais alimentos que causam alergias alimentares e para a prevenção da contaminação cruzada com alérgenos alimentares em qualquer estágio do seu processo de fabricação, desde a produção primária até a embalagem e comércio;

- Desenvolver e aplicar ferramentas de avaliação de impacto regulatório (AIR) para avaliação ex-post dos impactos da regulamentação sobre rotulagem de alimentos alergênicos e seus derivados;

- Aplicar as ferramentas de modelo lógico e de seleção e hierarquização de indicadores de MA em outros contextos regulatórios.

Finalmente, acredita-se que a ferramenta de seleção e hierarquização de indicadores de MA, com suporte dos métodos AHP e TOPSIS, bem como os indicadores e métricas resultantes de sua aplicação, poderão beneficiar as partes interessadas no processo da regulamentação sobre rotulagem de alimentos alergênicos e seus derivados no país. Principalmente, poderão contribuir para o monitoramento e avaliação do cumprimento do novo regulamento, que entrará em vigor a partir de 02 de julho de 2016. Busca-se com essa proposta de MA, minimizar a exposição do consumidor a produtos que possam representar um risco para sua saúde ou que estejam em desacordo com a legislação sanitária vigente. 


\section{Referências bibliográficas}

ABNT. Sistema de gestão da segurança de alimentos - Requisitos para qualquer organização na cadeia produtiva de alimentos. Rio de Janeiro: Associação Brasileira de Normas Técnicas, 2006.

AKIYAMA, $\mathrm{H}$. et al. Japan food allergen labeling regulation - history and evaluation. Adv Food Nutr Res., v.62, p.139-71, 2011.

ALLEN, K.J. et al. Precautionary labelling of foods for allergen content: are we ready for a global framework? World Allergy Organization Journal, v. 7, n.10, p. 1-14, 2014.

ANMAT. Guía para la gestión de alérgenos en la industria alimentaria. Administración Nacional de Medicamentos, Alimentos y Tecnología Médica, República de Argentina, 2013. Disponível em: < http://www.conal.gob.ar/recomendaciones/items/alergenos.pdf >. Acesso em: 8 fev. 2016.

ANVISA. Agência Nacional de Vigilância Sanitária. Consulta pública n ${ }^{\circ}$ 29, de 05 de junho de 2014. Brasília, DF, 2014a. Disponível em: < http://portal.anvisa.gov.br>.Acesso em: 16 out.2015.

ANVISA. Agência Nacional de Vigilância Sanitária. Comitê do Codex Alimentarius. Brasília, 2015a. Disponível em: <http://s.anvisa.gov.br/wps/s/r/i4 >. Acesso em: 3.mai.16.

ANVISA. Agência Nacional de Vigilância Sanitária. Guia sobre programa de controle de alergênicos. Versão 1. Brasília, DF: Anvisa, 2016 a.

ANVISA. Agência Nacional de Vigilância Sanitária. Justificativa: Proposta de Resolução de Diretoria Colegiada que dispõe sobre rotulagem de alergênicos em alimentos. Agência Nacional de Vigilância Sanitária, 2013. Disponível em: < http://portal.anvisa.gov.br>. Acesso em: 15 out. 2015.

ANVISA. Agência Nacional de Vigilância Sanitária. Legislação de boas práticas de fabricação. Brasília, 2015b. Disponível em: < http://www.anvisa.gov.br/alimentos/bpf.htm>. Acesso em: 16 out. 2015.

ANVISA. Agência Nacional de Vigilância Sanitária. Lei n 10.674 de 16 de maio de 2003. Brasília DF, 2003a. Disponível em: < http://portal.anvisa.gov.br/wps/wcm/connect/e62b4c804745968e9e65de3fbc4c67 35/lei_10674.pdf?MOD=AJPERES >. Acesso em: 16 out. 2015. 
ANVISA. Agência Nacional de Vigilância Sanitária. Perguntas e respostas sobre rotulagem de alimentos alergênicos. Anvisa. Gerência de Avaliação de Risco e Eficácia para Alegações. Gerência Geral de Alimentos. 2016. Disponível em: < http://portal.anvisa.gov.br/documents>. Acesso em: 23 mai. 2016.

ANVISA. Agência Nacional de Vigilância Sanitária. Regulamento técnico sobre rotulagem de alimentos embalados, Resolução RDC $n^{\circ} 259$, de 20 de setembro de 2002. Brasília DF, 2002. Disponível em: < http://portal.anvisa.gov.br/wps/wcm/connect/36bf398047457db389d8dd3fbc4c67 35/RDC_259.pdf?MOD=AJPERES >. Acesso em: 16 out. 2015.

ANVISA. Agência Nacional de Vigilância Sanitária. Regulamento técnico sobre rotulagem nutricional de alimentos embalados, tornando obrigatória a rotulagem nutricional, Resolução RDC $\mathrm{n}^{\circ} 360$ de dezembro de 2003. Brasília, DF, 2003b. Disponível em: < http://portal.anvisa.gov.br>. Acesso em: 04 mai. 2016.

ANVISA. Agência Nacional de Vigilância Sanitária. Relatório de Análise de Contribuições em Consulta Pública no 29/2014 e Audiência Pública. Agência Nacional de Vigilância Sanitária. Brasília, DF, 2014d.

ANVISA. Agência Nacional de Vigilância Sanitária. Resolução - RDC n ${ }^{\circ} 26$ de 2 de Julho de 2015. Brasília: Diário Oficial da União, 2015c.

ANVISA. Agência Nacional de Vigilância Sanitária. Resultado da Consulta Pública $n^{\circ}$ 29/2014 - Rotulagem de Alergênicos em Alimentos. Agência Nacional de Vigilância Sanitária, Brasília, DF, 2014c. Disponível em: < http://formsus.datasus.gov.br/site/resultado.php?id_aplicacao=16061 >. Acesso em: 11 nov. 2015.

ARMIJO, M. Planificación estratégica e indicadores de desempeño en el sector público. Santiago de Chile: ONU Instituto Latinoamericano y del Caribe de Planificación Económica y Social (ILPES), 2011. Disponível em: < http://www.cepal.org/ilpes/publicaciones/xml/8/44008/SM_69_MA.pdf >. Acesso em: 16 out. 2015.

ASSOCIAÇÃO BRASILEIRA DE ALERGIA E IMUNOLOGIA. Alergia alimentar. http://www.asbai.org.br/secao_detalhes.asp?s=81\&id=851, p. Que é alergia, alimentos envolvidos, principais alimentos, 2015. Acesso em: 06. oct. 2015 .

BAPTISTA, P. Sistemas de segurança alimentar na cadeia de transporte e distribuição de produtos alimentares. Portugal: Forvisão, 2007. ISBN 253361/07. Disponível em: https://elearning.iefp.pt/pluginfile.php/47923/mod_resource/content/0/manualvol3.pdf >. Acesso em: 26 abr. 2016. 
BARNETT, J. et al. Using 'may contain' labelling to inform food choice: a qualitative study of nut allergic consumers. BMC Public Health, v. 11, p. 734, 2011.

BELIK, W. Perspectivas para segurança alimentar e nutricional no Brasil. Saúde e Sociedade, v. 12, p. 12-20, 2003. Disponível em: < http://www.scielo.br/pdf/sausoc/v12n1/04.pdf >. Acesso em: 8 out. 2015.

BELIK, W.; SILIPRANDI, E. Hábitos alimentares, segurança e soberania alimentar. 2010. Disponível em: < http://www.fef.unicamp.br/fef/sites/uploads/deafa/qvaf/evolucao_cap20.pdf >. Acesso em: 8 out. 2015.

BONNEFOY, J. C.; ARMIJO, M. Indicadores de desempeño en el sector público. Santiago de Chile: ONU e Instituto Latinoamericano e del Caribe de Planificación Económica y Social, 2005. ISBN 9213228007/16808878. Disponível em: http://repositorio.cepal.org/bitstream/handle/11362/5611/S05900_es.pdf >.

BRANDIMARTI, L. Comer é questão de vida ou de morte. Banas Qualidade, v. 8, n. n.85, p. 34-39, 1999.

BRASIL. Indicadores de programas. Guia Metodológico. Brasília: Ministério do Planejamento, Orçamento e Gestão: 128 p. 2010.

BRASIL. Indicadores: Orientações básicas aplicadas à gestão pública. Brasília DF: República Federativa do Brasil Ministério do Planejamento, Orçamento e Gestão. 2012.

BRASIL. Lei $\mathbf{n}^{\circ}$ 8.078, de 11 setembro de 1990. Código de Defesa do Consumidor. Brasília, DF 12. set. 1990: Diário Oficial da República Federativa do Brasil 1990.

CANADA, H. The Canadian Act for the establishment of new priority food allergens. 2010. ISSN 978-1-100-14632-4. Disponível em: <http://www.hcsc.gc.ca/fn-an/pubs/label-etiquet/crit/index-eng.php >. Acesso em: 19 out. 2015.

CAPIOTTO, G. M.; LOURENZANI, W. L. Sistema de gestão de qualidade na indústria de alimentos. Caracterização da norma ABNT NBR ISO 22.000:2006. $48^{\circ}$ Congresso SOBER - Sociedade Brasileira de Economia Administração e Sociologia Rural Tecnologia, Desenvolvimento e Integração Social, 2010.

CASSIOLATO, M.; GUERESI, S. Como elaborar modelo lógico de programas: roteiro para formular programas e organizar avaliação. Nota técnica, nº 6. Brasília. DF: Ipea 2010.

CASWELL, J. A.; NOELKE, C. M.; MOJDUSZKA, E. M. Unifying two frameworks for analyzing quality and quality assurance for food products. Global food trade and consumer demand for quality, Kluwer Academic/Plenum, p. 
43-61, 2002. Disponível em: < http://link.springer.com/chapter/10.1007\%2F978$1-4757-5329-5 \_3>$.

CHADDAD, M. C. C. Informação sobre a presença de alergênicos nos rótulos de alimentos: responsabilidade do Estado na garantia dos direitos à saúde e à alimentação adequada da população com alergia alimentar. Alimentação, Nutrição \& saúde, v. 9, p. 369-392, 2014. Disponível em: < http://www.epublicacoes.uerj.br/index.php/demetra/article/view/10350\#.Vv1bZfnhDIU >. Acesso em: 31.jan.3016.

CHEFTEL, J. C. Food and nutrition labelling in the European Union. Food Chemistry, v. 93, n. 3, p. 531-550, 12// 2005. ISSN 0308-8146. Disponível em: < http://www.sciencedirect.com/science/article/pii/S0308814604008581 >.

COSTA, H. G. Auxilio multicritério à decisão: método AHP. Rio de Janeiro: Abepro, 2006. ISBN 85-88478-30-7.

COSTA, H. G. IPÊ 1.0: Guia do Usuário. Niterói: Universidade Federal Fluminense, 2004. Disponível em: < http://www.producao.uff.br/conteudo/rpep/volume42004/RelPesq_V4_2004_05.p df $>$.

COUTINHO, G. J.; RECINE, E. Experiências internacionais de regulamentação das alegações de saúde em rótulos de alimentos. Revista Panamericana Salud Publica, v. 22, p. 437, 2007.

CREVEL, R. Food allergens: identifying thresholds and assessing the risk to consumers. New Food, v. 16, p. 60-63, 2013.

DEUS, F. J. T.; SÁ, P. F. G. Evolução da normatização de boas práticas de fabricação (BPF) e o seu impacto na qualidade de medicamentos comercializados no Brasil. Produção Científica da Pós-Graduação Lato Sensu da PUC- Goiás, 2011. Disponível em: < http://www.cpgls.pucgoias.edu.br/6mostra/artigos/SAUDE/FERNANDO\%20JUS TINO\%20TORRES\%20DE\%20DEUS.pdf >.

DORAN, G. T. There's a S.M.A.R.T. way to write management's goals and objectives. Management Review, v.70, n.11, p. 35-36, 1981.

DUTRA, C. C.; FOGLIATTO, F. S. Operacionalização do processo analítico hierárquico usando matrizes incompletas de comparações pareadas. Anais do XXXIX simpósio Brasileiro de Pesquisa Operacional, p. Fortaleza, 2007.

EUROPEIA, U. Regulamento (UE) N1169-2011 do Parlamento Europeu e do Conselho. Diario Oficial da União Europeia 2011.

FALCPA. Food Allergen Labeling and Consumer Protection Act of 200421 USC 301 note Public Law 108-282. Food Allergen Labeling and Consumer Protection 2004. 
FEDERACIÓN ESPAÑOLA DE INDUSTRIAS DE ALIMENTACIÓN E BEBIDAS, F. Guía de Gestión de Alérgenos en la Industria Alimentaria. Food Drink Europe 2013.

FERNANDEZ, M. S. Qualidade dos alimentos e bebidas. Controle de Qualidade, v. 21, p. 10-22, 1994.

FERREIRA, H.; CASSIOLATO, M.; GONZALEZ, R. Uma experiência de desenvolvimento metodológico para avaliação de programas: o modelo lógico do Programa Segundo o Tempo. Texto para discussão n ${ }^{\circ}$ 1.369. Brasília, DF: Ipea 2009.

FIGUEIREDO, V. F.; COSTA NETO, P. L. O. Implantação do HACCP na indústria de alimentos. Gestão \& Produção, v. 8, n. n.1, p. 100 - 111, 2001.

FOOD ALLERGY RESEARCH \& EDUCATION, F. Food Labels. 2006. Disponível em: < http://www.foodallergy.org/food-labels >. Acesso em: 15/Oct/2015.

FOOD ALLERGY RESEARCH \& RESOURCE PROGRAM. Componentes de un plan eficaz de control de alérgenos. Una estructura para los procesadores de alimentos. 2009.

\section{FOOD STANDARDS AUSTRALIA NEW ZEALAND, F. Allergen Collaboration. 2014. Disponível em: < http://www.foodstandards.gov.au/consumer/foodallergies/Pages/default.aspx >. Acesso em: 14/Oct/2015.}

FOOD STANDARDS AUSTRALIA NEW ZEALAND. Allergen Review. 2015a.

Disponível em:

http://www.foodstandards.gov.au/consumer/foodallergies/review/pages/default.as px >. Acesso em: 3.Mar.

FOOD STANDARDS AUSTRALIA NEW ZEALAND. Consumer study on food allergen labelling: follow-on survey 2008-09. Evaluation Report Series n. 20. 214 p. 2009.

FOOD STANDARDS AUSTRALIA NEW ZEALAND. Food Standards Code. $2015 b$. Disponível em:

http://www.foodstandards.gov.au/code/Pages/default.aspx >. Acesso em: 15.03.2016

FSANZ. Warning and Advisory Statements and Declarations User Guide to Standard 1.2.3 - Mandatory Warning and Advisory Statements and Declarations. LEGISLATION, F. R. O. 2014.

GENDEL, S. M. The regulatory challenge of food Allergens. Food Chemistry, v. 61, p. 5634 - 5637, 2013. Disponível em: < http://pubs.acs.org/doi/abs/10.1021/jf302539a >. 
GONÇALVES, R. W.; PINHEIRO, P. R.; FREITAS, M. A. D. S. Métodos multicritérios como auxílio à tomada de decisão na bacia hidrográfica do Rio Curu - estado do Ceará. 2009.

GRACIA, A.; DE-MAGISTRIS, T. Consumer preferences for food labeling: What ranks first? Food Control, v. 61, p. 39-46, 3// 2016.

HATTERSLEY, S.; CHAN, C-H. Labelling of allergenic foods of concern in Europe. Innovations in Food Labelling, v. 2010, p. 59-74, 2010.

HATTERSLEY, S.; WARD, R. Regulatory Controls for Food Allergens. Risk Management for Food Allergy, v. 2014, p. 273-289, 2014.

HAWKES, C. Informação Nutricional e Alegações de Saúde: o cenário global das regulamentações. Brasília: Organização Pan-Americana da Saúde, Agência Nacional de Vigilância Sanitária: 2006.

HEFLE, S. L.; NORDLEE, J. A.; TAYLOR, S. L. Allergenic Foods. Crit Rev Food Sci Nutr, v.36 (Suppl):S69-S89, 1996.

HWANG, C.-L.; YOON, K. Multiple attribute decision making. New York: 1981. ISBN 13:978-3-540-10558-9.

IBGE. Indicadores de desenvolvimento sustentável. Instituto Brasileiro de Geografia e Estatística. Rio de Janeiro, Brasil 2008.

INMETRO. Comite Codex Alimentarius. Brasil, 2012. Disponível em: < http://www.inmetro.gov.br/qualidade/comites/codex.asp>. Acesso em: 3.mai.2016.

ISO. ISO 22000:2005 Food Safety Management Systems. Genebra: International Organization for Standardization 2005.

JANNUZZI, P. D. M. Considerações sobre o uso, mau uso e abuso dos indicadores sociais na formulação e avaliação de políticas públicas municipais. Revista de Serviço Público, v. 36, p. 72, 2002.

KJELKEVIK, R.; EDBERG, U.; MALMHEDEN YMAN, I. Labelling of potential allergens in food. Environmental Toxicology and Pharmacology, v. 4, n. 1-2, p. 157-162, 1997.

KROHLING, R. A.; SOUZA, D. T. T. M. Dois exemplos da aplicação da técnica TOPSIS para tomada de decisão. Revista Sistemas de Informação da FSMA, v. 8, p. 31-35, 2011.

LIMA, B. T. P. D.; CARVALHO JR, L. C. D. A importância da padronização de processos e gerenciamento no sector de fast-food em Florianópolis. Universidade Federal de Santa Catarina, 2012. Disponível em: < http://www.apec.unesc.net/VI_EEC/sessoes_tematicas/Tema5-

Economia\%20Industrial/Artigo-2-Autoria.pdf > . Acesso em: 28.Abr.2016. 
LOCKE, E. A.; LATHAM, G. P. A theory of goal setting and task performance. Englewood Cliffs, NJ: Prentice-Hall, 1990.

LOCKE, E. A.; LATHAM, G. P. Building a practically useful theory of goal setting and task motivation: A 35-year odyssey. American Psychologist, v.57, n.9, p.705-717, 2002.

LOCKE, E. A.; LATHAM, G. P. Goal setting-A motivational technique that works. Organizational Dynamics, v.8, n.2, p.68-80, 1979.

LOCKE, E. A.; LATHAM, G. P. New directions in goal-setting theory. Current Directions in Psychological Science, v.15, n.5, p.265-268, 2006.

LUBER, P. The Codex Alimentarius guidelines on the application of general principles of food hygiene to the control of Listeria monocytogenes in ready-toeat foods. Food Control, v. 22, n. 9, p. 1482-1483, 2011.

MARINS, B. R.; TANCREDI, R. C. P.; GERMAL, A. L. Segurança alimentar no contexto da Vigilância Sanitária: reflexões e práticas. Brasília, 2014.

MHLW. Ministry of Health Labour and Welfare. 2011. Disponível em: < http://www.mhlw.go.jp/english/policy/health-medical/food/index.html >. Acesso em: 18.out.2015.

MURARO, A. et al. Protecting consumers with food allergies: understanding food consumption, meeting regulations and identifying unmet needs. Allergy, v.69, p. 1464-1472, 2014.

PEREIRA, R. D. A. Aplicação do método AHP na redução de multas em empresas de telecomunicações. 2010. 104 p. Centro de Ciências Exactas, Ambientales e de Tecnologías, Pontificia Universidade Católica de Campinas, Campinas.

SAATY, T. L. Desicion making by the analytic hierarchy process: Theory and applicationsPhysics as a decision theory. European Journal of Operational Research, v. 48, n. 1, p. 98-104, 1990/09/05 1990. ISSN 0377-2217. Disponível em: < http://www.sciencedirect.com/science/article/pii/037722179090066K >.

SAATY, T. L. Método de análise hierárquica. São Paulo: Mc - Graw Hill, 1991.

SAATY, T. L. A scaling method for priorities in hierarchical structures. Journal of Mathematical Psychology, v. 15, n. 3, p. 234-281, 6// 1977. ISSN 0022-2496. Disponível em: http://www.sciencedirect.com/science/article/pii/0022249677900335 >.

SAATY, T. L. Decision making for leaders. University of Pittsburgh, 2000. ISBN 0-9620317-8-X. Disponível em: < https://books.google.com.br/books?hl=es\&lr=\&id=c8KqSWPFwIUC\&oi=fnd\&pg $=\mathrm{PT} 8 \& \mathrm{dq}=\mathrm{decision}+$ making + for + leaders $+2000 \&$ ots $=2 \mathrm{KQPHmHKTm} \& \mathrm{sig}=\mathrm{viX} 4$ 
yTdv0y59tHJ-

gqi91bnF43U\#v=onepage \&q=decision\%20making\%20for\%20leaders\%202000\&f $=$ false $>$. Acesso em: 30.mai. 2016.

SAATY, T. L.; VARGAS, L. G. Models, methods, concepts \& applications of the analytic hieratchy process. Second Edition. New York: International Series in Operations Research \& Management Science, 2012. ISBN 978-1-4614-3596-9.

SILVA, L. A.; CORREIA, A. D. F. K. Manual de boas práticas de fabricação para indústria fracionadora de alimentos. Revista Ciencia \& Tecnología, v. 16, n. 32, p. $39-57,2009$.

SIMMONS, S. Reducción de las alergias alimentares. Nursing (ed. española), p. $38-45,2015$.

SOLÉ, D. et al. Consenso Brasileiro sobre Alergia Alimentar: 2007. Revista Brasileira Alergia Inmunopatologia, v. 31, n.2, p.34-38, 2008.

TANAKA, O. Y.; MELO, C. Avaliação de programas de saúde do adolescente: um modo de fazer. Universidade de São Paulo: Universidade de São Paulo, 2001.

TAYLOR, S. L.; HEFLE, S. L. Food allergen labeling in the USA and Europe. Current Opinion in Allergy and Clinical Immunology, v. 6, n. 3, p. 186-190, 2006.

TAYLOR, S. L.; HEFLE, S. L. Ingredient and labeling issues associated with allergenic foods. Allergy: European Journal of Allergy and Clinical Immunology, Supplement, v. 56, n.67, p. 64-69, 2001.

THE CENTER FOR FOOD SAFETY AND APPLIED NUTRITION; ADMINISTRATION, F. A. D.; SERVICES, U. D. O. H. A. H. Approaches to Establish Thresholds for Major Food Allergens and for Gluten in Food 2006.

TRIENEKENS, J.; ZUURBIER, P. Quality and safety standards in the food industry, developments and challenges. International Journal of Production Economics, v. 113, n. 1, p. 107-122, 5// 2008. ISSN 0925-5273. Disponível em: < http://www.sciencedirect.com/science/article/pii/S092552730700312X >. Acesso em: 28 abr. 2016.

VERGARA, S. C. Metodologia do trabalho científico. São Paulo: Cortez, 2002.

VERGARA, S. C. Métodos de pesquisa em administração. São Paulo: Atlas, 2005.

VIEIRA, C. P. A. et al. Mecanismos organizacionais como resposta à informação imperfeita - a questão da segurança dos alimentos. Informações Econômicas SP, v. 37, p. 23, 2007.

VILLELA, T. M. D. A. et al. Metodologia para desenvolvimento e seleção de indicadores para planejamento de transportes. CEFTRU, 2007. Disponível em: 
https://www.researchgate.net/publication/267962892_metodologia_para_desenvol vimento_e_selecao_de_indicadores_para_planejamento_de_transportes $>$. Acesso em: 25.mar.2016.

WHO/ FAO. Codex Alimentarius International Food Standards. WHO/FAO, 2016. Disponível em: <http://www.codexalimentarius.org/about-codex/en>. Acesso em: 3.mai.2016.

WHO/FAO. Comisión del Codex Alimentarius - Manual de procedimiento. Roma: Programa conjunto FAO/OMS sobre normas alimentárias. 2015.

WHO/FAO. Garantía de la inocuidad y calidad de los alimentos: Directrices para el fortalecimiento de los sistemas nacionales de control de los alimentos 2003.

YOO, C. W.; PARAMESWARAN, S.; KISHORE, R. Knowing about your food from the farm to the table: Using information systems that reduce information asymmetry and health risks in retail contexts. Information \& Management, v. 52, n. 6, p. 692-709, 9// 2015.

ZURZOLO, G.A. et al. Perceptions of precautionary labelling among parents of children with food allergy and anaphylaxis. J. Med J Aust., v. 198, n. 11, p. 621623, 2013. 


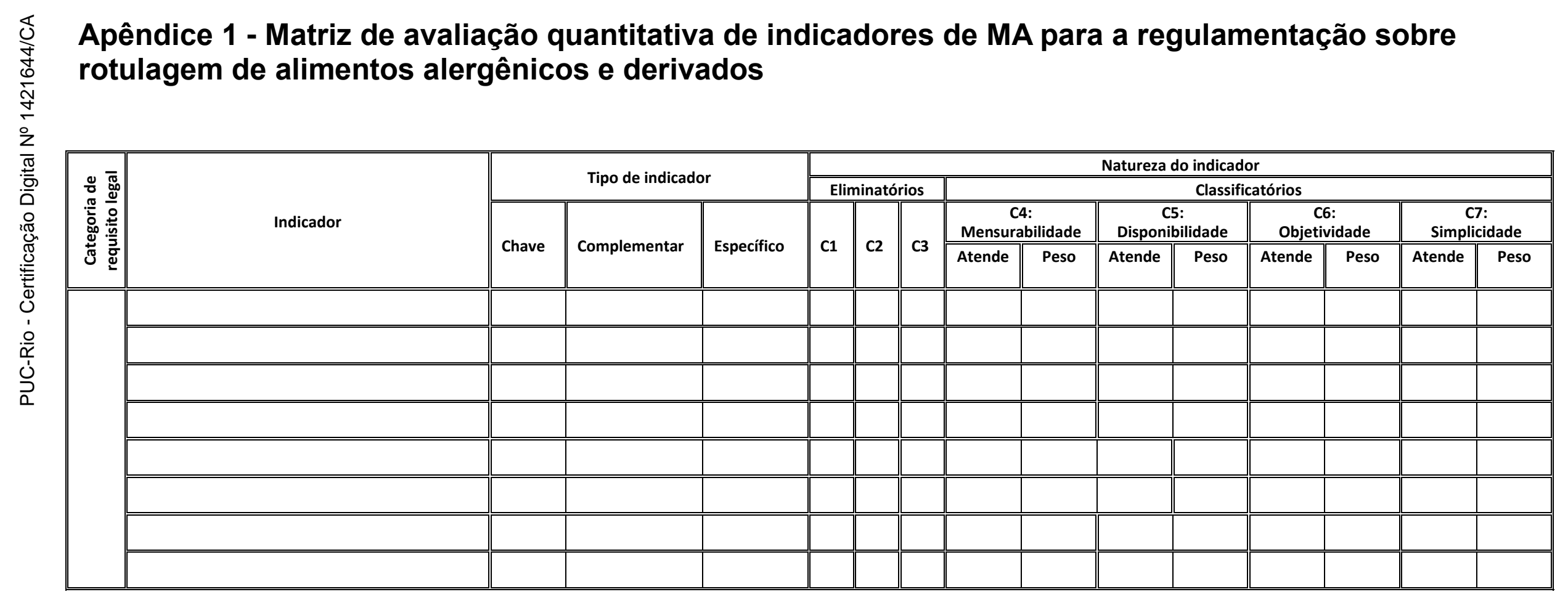

Legenda: Critérios eliminatórios: C1 - Atendimento às necessidades de informação dos interessados; C2 - Rastreabilidade ao longo do tempo; C3 - Representatividade (em relação ao objetivo e requisitos da regulamentação em foco.

Critérios classificatórios: C4 - Mensurabilidade; C5 - Disponibilidade; C6 - Objetividade; C7 - Simplicidade.

Pesos dos critérios classificatórios: calculados pelo método AHP.

Graus para o campo "atende ao critério": grau superior 9 - atende totalmente; grau inferior 1 - não atende ao critério. Graus intermediários - 7, 5 e 3. 


\section{Anexo 1 - Descrição do método analítico hierárquico - AHP}

Este anexo é parte integrante da dissertação de Ariani Mello intitulada "Monitoramento e avaliação da regulamentação sobre recolhimento de alimentos no Brasil: proposição de indicadores e métricas" (Mello, 2015). Descreve-se a seguir o método AHP conforme o proposto por Saaty (1977, 1991, 2008).

O método AHP compreende quatro etapas, de acordo com a descrição de Saaty (1991) e Costa (2006):

- Organização da estrutura hierárquica, através da identificação do foco principal, dos critérios e subcritérios (quando existirem) e das alternativas, refletindo as relações existentes entre eles;

- Aquisição dos dados e coleta de julgamentos de valor, através da comparação dos elementos dois a dois e estabelecimento das matrizes de comparações;

- Análise das matrizes de comparações geradas na fase anterior, que indicarão a prioridade de cada alternativa em relação ao foco principal;

- Análise dos indicadores de desempenho derivados, como índices de consistência por exemplo.

No AHP, os elementos de uma hierarquia para a resolução de problemas de decisão são o foco principal (ou meta), o conjunto de alternativas viáveis e o conjunto de critérios, de acordo com o ilustrado na Figura 1.

O foco principal é o objetivo global, o que a resolução do problema trará. As alternativas viáveis são as possibilidades de escolha dentro do problema para que a decisão seja tomada. Por fim, os critérios são as características ou propriedades a partir das quais as alternativas devem ser avaliadas.

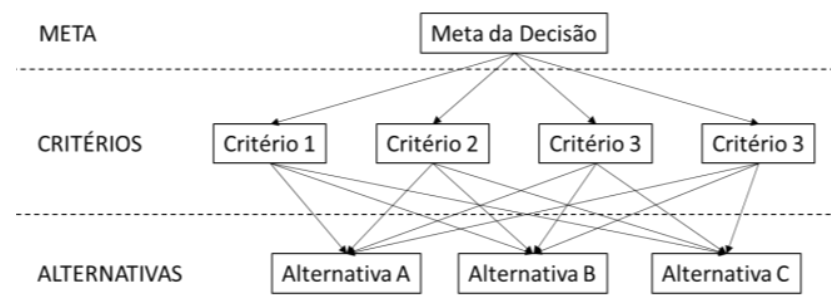

Figura 1 - Exemplo de estrutura hierárquica de problemas de decisão (em três níveis) Fonte: Saaty, 1991. 
Após a hierarquização, o método aponta para os julgamentos de valor, onde o avaliador deve comparar os elementos dois a dois à luz de um determinado critério. O julgamento é então a representação numérica dessa relação e o grupo de todos os julgamentos, considerando a comparação de todos os elementos em relação a um critério específico, pode ser representado através de uma matriz quadrada (Saaty, 1991).

Para o estabelecimento do processo de julgamento, Saaty (1990) definiu uma escala específica para padronizar os julgamentos de valor, escala essa que capta a subjetividade natural existente em variáveis qualitativas. O Quadro 14, a seguir, apresenta essa escala.

Quadro 1 - Escala para padronizar os julgamentos de valor pelo método AHP

\begin{tabular}{|c|c|c|}
\hline $\begin{array}{l}\text { Intensidade de } \\
\text { importância }\end{array}$ & Definição & Explicação \\
\hline 1 & Mesma importância & $\begin{array}{l}\text { As duas atividades contribuem } \\
\text { igualmente para o objetivo. }\end{array}$ \\
\hline 3 & $\begin{array}{l}\text { Importância moderada de uma } \\
\text { sobre a outra }\end{array}$ & $\begin{array}{l}\text { A experiência e o julgamento favorecem } \\
\text { levemente uma atividade em relação à } \\
\text { outra. }\end{array}$ \\
\hline 5 & Importância grande ou essencial & $\begin{array}{l}\text { A experiência e o julgamento favorecem } \\
\text { fortemente uma atividade em relação à } \\
\text { outra. }\end{array}$ \\
\hline 7 & $\begin{array}{l}\text { Importância muito grande ou } \\
\text { demonstrada }\end{array}$ & $\begin{array}{l}\text { Uma atividade é muito fortemente } \\
\text { favorecida em relação à outra; sua } \\
\text { dominação de importância é } \\
\text { demosntrada na prática. }\end{array}$ \\
\hline 9 & Importância absoluta & $\begin{array}{l}\text { A evidência favorece uma atividade em } \\
\text { relação à outra com o mais alto grau de } \\
\text { certeza. }\end{array}$ \\
\hline $2,4,6,8$ & $\begin{array}{l}\text { Valores intermediários entre os } \\
\text { valores adjacentes. }\end{array}$ & $\begin{array}{l}\text { Quando se procura uma condição de } \\
\text { compromisso entre as duas definições. }\end{array}$ \\
\hline
\end{tabular}

Fonte: Saaty, 1991.

O julgamento consiste no reflexo de duas perguntas: qual dos dois elementos é o mais importante, à luz do objetivo pretendido, e com qual intensidade ele é mais importante, utilizando-se a escala de 1 a 9 apresentada no Quadro 1.

Para o elemento mais importante, é utilizado um valor inteiro, enquanto que o menos importante recebe o inverso dessa unidade, como ilustrado no exemplo didático da Figura 2. 


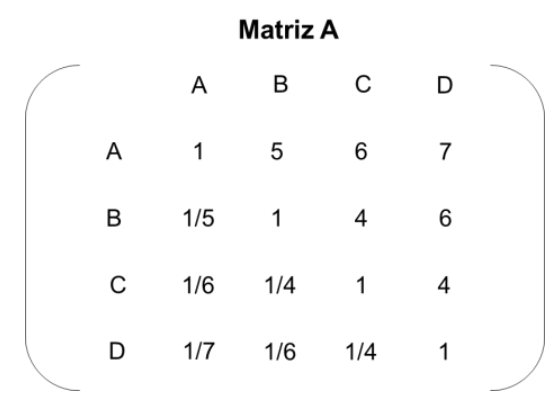

Figura 2 - Exemplo de matriz de julgamentos para o método AHP Fonte: Saaty, 1991.

As letras A, B, C e D representam os elementos a serem comparados dois a dois. A diagonal da matriz recebe sempre 1 pois é a comparação do elemento com ele mesmo. Para o preenchimento dos outros campos, são feitos os julgamentos para determinar a intensidade de importância, utilizando a escala determinada por Saaty. Para as comparações inversas, ou seja, o que está na parte inferior esquerda da matriz, são adicionados os valores recíprocos referentes à cada julgamento, que estão na parte superior direita da mesma.

Com as matrizes recíprocas devidamente estruturadas, obtém-se o vetor de prioridades, ou pesos, a partir do cálculo do autovetor normalizado do máximo autovalor. Existem métodos específicos para o cálculo aproximado desses valores (Saaty,1991). Tais aproximações foram desenvolvidas por limitações computacionais da época em que o método foi desenvolvido, sendo custoso o cálculo de autovetores e autovalores para matrizes de ordem elevada.

Para fins deste trabalho, será utilizado o valor preciso de ambas as grandezas, que são denotadas matricialmente por:

$$
A w=\lambda_{\max } w
$$

Onde:

$A$ é a matriz de julgamentos (quadrada, recíproca e positiva);

$w$ é o autovetor principal, referente aos pesos;

$\lambda_{\text {max }}$ é o autovalor principal de $A$.

Com as características das matrizes de julgamentos em mãos, através do teorema de Perron-Frobenius, Saaty (1991) afirma que a solução tem um único 
maior autovalor que corresponde a um autovetor de componentes estritamente positivos. Os teoremas e as provas acerca das características envolvendo as matrizes geradas, a partir da avaliação de especialistas, são apresentados em seu trabalho. Computados os autovalores das respectivas matrizes, é necessário realizar análise da consistência dos julgamentos para avaliar o quão afastado da consistência os julgamentos estão. Utiliza-se uma medida para avaliar a probabilidade dos julgamentos terem sido realizados puramente ao acaso e esta medida é chamada Razão de Consistência (RC). Por exemplo, um $R C=0,3 \mathrm{diz}$ que há $30 \%$ de chance do especialista responder as perguntas aleatoriamente.

Saaty (1991) apresenta um desenvolvimento simples e intuitivo para compreender a análise de consistência. Vamos supor uma matriz consistente, onde as comparações são baseadas em medidas exatas, isto é, os pesos já são conhecidos, então:

$$
a_{i j}=\frac{w_{i}}{w_{j}}
$$

Como o julgamento é perfeito para todas as comparações, tem-se que $a_{i k}=a_{i j} . a_{j k}$ para qualquer $\mathrm{i}, \mathrm{j}, \mathrm{k}$, variando de 1 até $n$, sendo $n$ a ordem da matriz.

Também vale a afirmativa:

$$
a_{i j}=\frac{w_{j}}{w_{i}}=\frac{1}{w_{i} / w_{j}}=\frac{1}{a_{i j}}
$$

Dessa forma caracteriza-se uma matriz consistente de comparações paritárias.

Considerando $x=\left(x_{1}, \ldots, x_{n}\right)$ e $y=\left(y_{1}, \ldots, y_{n}\right)$ pode-se escrever em notação matricial $A \cdot x=y$, onde A é a matriz de julgamentos:

$$
A=\left[\begin{array}{ccc}
\frac{w_{1}}{w_{1}} & \cdots & \frac{w_{1}}{w_{n}} \\
\vdots & \ddots & \vdots \\
\frac{w_{n}}{w_{1}} & \cdots & \frac{w_{n}}{w_{n}}
\end{array}\right]
$$

Algebricamente essa operação pode ser representada por:

$$
\begin{aligned}
& \sum_{j=0}^{n} a_{i j} \cdot x_{i}=y_{i} \\
& \operatorname{para} i=1, \ldots, n
\end{aligned}
$$


Como $a_{i j}=\frac{w_{i}}{w_{j}}$, obtém-se:

$$
\begin{gathered}
a_{i j} \frac{w_{j}}{w_{i}}=1 \\
\operatorname{para} i, j=1, \ldots, n
\end{gathered}
$$

Consequentemente:

$$
\begin{aligned}
& \qquad \sum_{j=0}^{n} a_{i j} \cdot w_{j} \frac{1}{w_{i}}=n \\
& \text { para } i=1, \ldots, n
\end{aligned}
$$

ou

$$
\begin{aligned}
& \sum_{j=0}^{n} a_{i j} \cdot w_{j}=n w_{i} \\
& \operatorname{para} i=1, \ldots, n
\end{aligned}
$$

Que é equivalente a equação matricial:

$$
A w=n w
$$

Em álgebra linear, esta última equação expressa o fato de que $w$ é autovetor de $A$ com autovalor $n$.

$\mathrm{Na}$ prática $a_{i j}$ são os pesos atribuídos pelo julgamento dos especialistas, baseado na escala fundamental, e de certa forma subjetivos. Assim os valores $a_{i j}$ irão se afastar do "ideal" $w_{i} / w_{j}$, fazendo com que a equação $A w=n w$ não seja mais válida.

Se $\lambda_{1}, \ldots, \lambda_{n}$ são os números que satisfazem a equação $A w=\lambda w$, então $\lambda$ é autovalor de $A$ e, se $a_{i j}=1$ para todo i, então:

$$
\sum_{i=0}^{n} \lambda_{i}=n
$$

Assim, se $A w=n w$ é válida, somente um dos autovalores é diferente de zero e valerá $n$, sendo o maior autovalor de $A$.

Caso os elementos de uma matriz recíproca positiva sofrerem pequenas variações, seus respectivos autovalores também variarão em pequenas quantidades. 
Utilizando os resultados apresentados juntamente com o axioma acima, pode-se dizer que caso a diagonal principal de uma matriz possuir os elementos iguais a 1 e for consistente, pequenas variações nos elementos $a_{i j}$ farão com que o autovalor máximo $\lambda_{\max }$ permaneça próximo de $n$ e os outros autovalores próximos de zero. Sendo $\lambda_{\max } \geq n$.

Portanto, para calcular o autovetor de prioridades de uma matriz de comparações paritárias $A$, deve-se encontrar o vetor que satisfaça a equação $A w=\lambda_{\max } w$.

O valor de interesse para o desenvolvimento da metodologia é o autovetor normalizado, de forma que a soma de $w$ seja igual a 1 . Para isso cada elemento $w_{i}$ é dividido pelo seu somatório.

Uma medida de consistência, chamada Índice de Consistência (IC), é utilizada para calcular o desvio de $\lambda_{\max }$ em relação à $n$, uma vez que a utilização da escala para os julgamentos geram variações em $a_{i j}$, alterando $\lambda_{\max }$.

$$
I C=\frac{\lambda_{\max }-n}{n-1}
$$

É comum as avaliações realizadas pelos especialistas gerarem inconsistências, pois faz parte do julgamento humano, mas deseja-se que sejam as menores possíveis. Para verificar a coerência utiliza-se, como citado anteriormente, a Razão de Consistência, tendo como definição:

$$
R C=\frac{I C}{I R}
$$

IR (Índice Randômico) é o índice de consistência de uma matriz recíproca gerada randomicamente, baseada na escala de 1 a 9, com recíprocas forçadas (Saaty, 1991). Este valor é tabelado e varia de acordo com a ordem da matriz. $\mathrm{Na}$ Tabela 1 é apresentado o valor de IR para matrizes de ordem 1 até 10.

Tabela 1 - Índice randômico

\begin{tabular}{c|cccccccccc}
$\mathbf{n}$ & 1 & 2 & 3 & 4 & 5 & 6 & 7 & 8 & 9 & 10 \\
\hline $\mathbf{I R}$ & 0 & 0 & 0,52 & 0,89 & 1,11 & 1,25 & 1,35 & 1,40 & 1,45 & 1,49
\end{tabular}

Fonte: Adaptado de Saaty e Vargas, 2012.

A avaliação final da coerência do julgamento se dá ao comparar o valor de RC. Para o presente desenvolvimento faz-se as seguintes considerações: 
a) $R C \leq 0,1$ consiste em um julgamento coerente, premissa básica do método em relação a análise de coerência, proposta inicialmente para julgar uma avaliação como satisfatória;

b) $0,1<R C<0,2$ = Julgamento questionável, considerado para que especialista reveja seus julgamentos da respectiva etapa, analisando a matriz construída e busque melhorar alguma(s) comparação(ões) que tenha(m) sido inconsistente(s). Porém não é obrigatório que se altere algum julgamento;

c) $R C \geq 0,2=$ Julgamento incoerente, indica que as comparações pareadas daquela etapa geraram um alto índice de inconsistência e o especialista é obrigado a refazer seus julgamentos.

Uma vez alcançada a consistência no julgamento, são calculados os vetores de prioridades, ou seja, os pesos relativos de cada elemento do problema. Este cálculo é realizado através da multiplicação das matrizes de prioridades. Em outras palavras, para cada alternativa, o cálculo consiste na soma ponderada da importância relativa de cada atributo pelo nível de preferência de determinada alternativa em relação ao respectivo critério (Souza, 2013). No AHP cada alternativa receberá uma pontuação através de uma função de valor aditiva. As alternativas com maior valor serão as preferíveis (Passos, 2010). Formalizando, a função de valor para cada alternativa será:

$$
F(a)=\sum_{j=1}^{n} w_{j} v_{j}(a)
$$

Onde:

$F(a)$ é o valor final de alternativa $a$;

$w_{j}$ é o peso do j-ésimo critério;

$v_{j}$ é o desempenho da alternativa em relação ao j-ésimo critério.

\section{Referências}

SAATY, T. L. A scaling method for priorities in hierarchical structures. Journal of Mathematical Psychology, v. 15, n. 3, p. 234-281, 1977.

SAATY, T. L. Decision making with the analytic hierarchy process. International Journal of Services Sciences, v.1, n.1, p. 83-98, 2008.

SAATY, T. L. Método de análise hierarquica. São Paulo: Mc - Graw Hill, 1991.

SAATY, T. L.; VARGAS, L. G. Models, methods, concepts \& applications of the analytic hieratchy process. $2^{\text {nd }}$. ed. New York: International Series in Operations Research \& Management Science, 2012. 


\section{Anexo 2 - Descrição da técnica para avaliar o desempenho de alternativas pela similaridade com a solução ideal - TOPSIS}

Este anexo é parte integrante da dissertação de Ariani Mello titulada "Monitoramento e avaliação da regulamentação sobre recolhimento de alimentos no Brasil: Proposição de indicadores e métricas” (Mello, 2015).

Descreve-se a seguir o método TOPSIS conforme o descrito por Hwang e Yoon, (1981)

Basicamente, a técnica compreende as seguintes etapas:

- Construção da matriz do problema ou matriz de decisão, que traz as alternativas e critérios selecionados juntamente com as notas e avaliações;

- Cálculo da matriz normalizada, utilizando normalização linear ou por vetor;

- Cálculo da matriz com os respectivos pesos de cada critério, definidos previamente por um ou mais decisores;

- Identificação da PIS e da NIS;

- Cálculo das distâncias entre a PIS e cada alternativa e entre a NIS e cada alternativa;

- Cálculo da similaridade para a posição ideal positiva, que vai definir a hierarquização das alternativas estudadas.

A matriz de decisão A composta por alternativas e critérios é apresentada abaixo:

$$
\begin{gathered}
C_{1} \\
A= \\
A_{1} \\
A_{m} \\
A_{m}
\end{gathered}\left(\begin{array}{ccc}
x_{11} & \ldots & C_{n} \\
\vdots & \ddots & \vdots \\
x_{m 1} & \cdots & x_{m n}
\end{array}\right)
$$

Onde $A_{1}, A_{2}, \ldots . A_{m}$ são alternativas viáveis e $C_{1}, C_{2}, \ldots . ., C_{n}$ são critérios; $x_{i j}$ indica o desempenho da alternativa $A_{i}$ segundo o ritério $C_{\mathrm{j}}$.

$\mathrm{O}$ vetor de peso $W=\left(w_{1}, w_{2}, \ldots . w_{n}\right)$ composto pelos pesos individuais para cada critério $C_{j}$ satisfaz

$$
\sum_{i=1}^{n} w_{j}=1
$$


Os dados da matriz A têm origens distintas, devendo ser normalizada com o objetivo de transformá-la em uma matriz adimensional e com isso proceder a uma comparação entre os vários critérios. Para fins de aplicação nesta pesquisa, a matriz A deve ser normalizada para cada critério $C_{j}$, de acordo com a seguinte fórmula:

$$
p_{i j}=\frac{x_{i j}}{\sum_{i=1}^{m} x_{i j}}, \operatorname{com} i=1, \ldots, m, j=1, \ldots, n
$$

Assim, uma matriz de decisão normalizada $A_{n}$ representa o desempenho relativo das alternativas e pode ser descrita por:

$$
A_{n}=\left(p_{i j}\right)_{m x n}, \operatorname{com} i=1, \ldots, m, \text { e } j=1, \ldots, n \text {. }
$$

O algoritmo para calcular a melhor alternativa segundo a técnica TOPSIS compreende os seguintes passos (Krohling e Souza, 2011):

Passo 1: Cálculo das soluções ideais positivas $A^{+}$(benefícios) e das soluções ideais negativas $A^{-}$(custos) da seguinte forma:

$$
\begin{aligned}
& A^{+}=\left(p_{1}^{+}, p_{2}^{+}, \ldots, p_{m}^{+}\right) \\
& A^{-}=\left(p_{1}^{-}, p_{2}^{-}, \ldots, p_{m}^{-}\right)
\end{aligned}
$$

Onde:

$$
\begin{gathered}
p_{j}^{+}=\left(\max _{i} p_{i j}, j \in J_{1} ; \min _{i} p_{i j}, j \in J_{2}\right) \\
p_{j}^{-}=\left(\min _{i} p_{i j}, j \in J_{1} ; \max _{i} p_{i j}, j \in J_{2}\right)
\end{gathered}
$$

Onde $j_{1} e j_{2}$ representam respectivamente o critério benefício e custo.

Passo 2: Cálculo das distâncias Euclideanas entre $A_{i}$ e $A^{+}$(benefícios) e entre $A_{i}$ e $A^{+}$(custos) da seguinte forma:

$$
\begin{gathered}
d^{+}=\sqrt{\sum_{j=1}^{n} w_{j}\left(p_{j}^{+}-p_{i j}\right)^{2}} \text { com } i=1, \ldots, m . \\
d^{-}=\sqrt{\sum_{j=1}^{n} w_{j}\left(p_{j}^{-}-p_{i j}\right)^{2}} \operatorname{com} i=1, \ldots, m .
\end{gathered}
$$


Passo 3: Calculo da proximidade relativa $\xi_{\text {i }}$ para cada alternativa $A_{i}$ em relação à solução ideal positiva $A^{+}$conforme:

$$
\xi_{i}=\frac{d_{i}^{-}}{d_{i}^{+}+d_{i}^{-}} .
$$

\section{Referências}

HWANG, C.-L.; YOON, K. Multiple Attribute Decision Making. Methods and applications New York: 1981.

KROHLING, R. A.; SOUZA, D. T. T. M. Dois exemplos da aplicação da técnica TOPSIS para tomada de decisão. Revista Sistemas de Informação da FSMA, v. 8, p. 31-35, 2011. 


\section{Anexo 3 - Proposta de Resolução (RDC) que dispõe sobre rotulagem de alergênicos em alimentos}

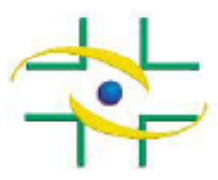

Agência Nacional de Vigilância Sanitária

www.anvisa.gov.br

Consulta Pública ${ }^{\circ}$ 29, de 05 de junho de 2014

D.O.U de 09/06/2014

A Diretoria Colegiada da Agência Nacional de Vigilância Sanitária, no uso da atribuição que lhe conferem os incisos III e IV, do art. 15, da Lei oㅜ 9.782, de 26 de janeiro de 1999, inciso III e $\S \S 1^{\circ}$ e $3^{\circ}$ do art. $5^{\circ}$ do Regimento Interno aprovado nos termos do Anexo I da Portaria no 650 da ANVISA, de 29 de maio de 2014, publicada no DOU de 02 de junho de 2014, tendo em vista o disposto nos incisos III, do art. $2^{\circ}$, III e IV, do art. $7^{\circ}$ da Lei no 9.782 de 1999, no art. 35 de Decreto no 3.029, de 16 de abril de 2009, e o programa de Melhoria do Processo de Regulamentação da Agência, instituído por meio da Portaria no 422 , de 16 de abril de 2008, em reunião realizada em 29 de maio de 2014, resolve submeter à consulta pública, para comentários e sugestões do público em geral, proposta de ato normativo, e eu, Diretor-Presidente, determino a sua publicação

Art. 1ํ Fica estabelecido o prazo de 60 (sessenta) dias para envio de comentários e sugestões ao texto da proposta de Resolução de Diretoria Colegiada que dispõe sobre Rotulagem de Alergênicos em Alimentos, conforme Anexo

Parágrafo único. O prazo de que trata este artigo terá início 7 (sete) dias após a data de publicação desta Consulta Pública no Diário Oficial da União.

Art. $2^{\circ}$ A proposta de ato normativo estará disponível na íntegra no portal da Anvisa na internet e as sugestões deverão ser enviadas eletronicamente por meio do preenchimento de formulário específico, disponível no endereço: http://formsus.datasus.gov.br/site/formulario.php?id_aplicacao=16061

$\S 1^{\circ}$ As contribuições recebidas são consideradas públicas e estarão disponíveis a qualquer interessado por meio de ferramentas contidas no formulário eletrônico, no menu "resultado", inclusive durante o processo de consulta.

$\S 2^{\circ}$ Ao término do preenchimento do formulário eletrônico será disponibilizado ao interessado número de protocolo do registro de sua participação, sendo dispensado o envio postal ou protocolo presencial de documentos em meio físico junto à Agência.

§3ํㅡㄹ Em caso de limitação de acesso do cidadão a recursos informatizados será permitido o envio e recebimento de sugestões por escrito, em meio físico, durante o prazo de consulta, para o seguinte endereço: Agência Nacional de Vigilância Sanitária/GGALI, SIA trecho 5, Área Especial 57, Brasília-DF, CEP 71.205-050.

$\S 4^{\circ}$ Excepcionalmente, contribuições internacionais poderão ser encaminhadas em meio físico, para o seguinte endereço: Agência Nacional de Vigilância Sanitária/ Núcleo de Assessoramento em Assuntos Internacionais (Naint), SIA trecho 5, Área Especial 57, Brasília-DF, CEP 71.205-050. 
Art. $3^{\circ}$ Findo o prazo estipulado no art. 1ํㅡ a Agência Nacional de Vigilância Sanitária promoverá a análise das contribuições e, ao final, publicará o resultado da consulta pública no portal da Agência.

Parágrafo único. A Agência poderá, conforme necessidade e razões de conveniência e oportunidade, articular-se com órgãos e entidades envolvidos com o assunto, bem como aqueles que tenham manifestado interesse na matéria, para subsidiar posteriores discussões técnicas e a deliberação final da Diretoria Colegiada.

DIRCEU BRÁS APARECIDO

PROPOSTA EM CONSULTA PÚBLICA

Processo no: 25351.296188/2011-21

Assunto: Proposta de Resolução de Diretoria Colegiada que dispõe sobre Rotulagem de Alergênicos em Alimentos

Agenda Regulatória 2013-2014: Tema № 22

Regime de Tramitação: Comum

Área responsável: GGALI

Relator: Renato Alencar Porto

RESOLUÇÃO DA DIRETORIA COLEGIADA - RDC № XX, DE XX DE XXXX DE 2014.

Dispõe sobre a declaração obrigatória na rotulagem de alimentos embalados das fontes reconhecidas por causarem alergias ou intolerâncias alimentares em pessoas sensíveis.

A Diretoria Colegiada da Agência Nacional de Vigilância Sanitária, no uso das atribuições que Ihe conferem os incisos III e IV, do art. 15 da Lei oㅜ 9.782, de 26 de janeiro de 1999, o inciso II, e $\S \S 1^{\circ}$ e 3 o do art. 54 do Regimento Interno aprovado nos termos do Anexo I da Portaria no 354 da ANVISA, de 11 de agosto de 2006, republicada no DOU de 21 de agosto de 2006, e suas atualizações, tendo em vista o disposto nos incisos III, do art. $2^{\circ}$, III e IV, do art. $7^{\circ}$ da Lei $n^{\circ}$ 9.782, de 1999, e o Programa de Melhoria do Processo de Regulamentação da Agência, instituído por meio da Portaria no 422, de 16 de abril de 2008, em reunião realizada em xxx de xxx de xxx, adota a seguinte Resolução de Diretoria Colegiada e eu, Diretor-Presidente, determino a sua publicação:

Art. 1ํ Fica aprovado o Regulamento Técnico que estabelece os requisitos para a declaração obrigatória, na rotulagem de alimentos embalados, das fontes reconhecidas por causarem alergias ou intolerâncias alimentares em pessoas sensíveis, nos termos desta Resolução.

Art. 2ํㅡㄹ Esta Resolução se aplica aos alimentos, ingredientes, aditivos alimentares, coadjuvantes de tecnologia e matérias-primas embalados na ausência dos consumidores, inclusive aqueles destinados exclusivamente ao processamento industrial e os destinados aos serviços de alimentação.

$\S 1^{\circ}$ Este regulamento se aplica de maneira complementar à Resolução RDC no 259 , de 20 de setembro de 2002, que aprova o regulamento técnico para rotulagem de alimentos embalados, e à Lei no 10.674, de 16 de maio de 2003, que estabelece a obrigatoriedade de informação sobre a presença de glúten em produtos alimentícios comercializados.

$\S 2^{\circ}$ Este regulamento não se aplica aos seguintes produtos: 
I - alimentos embalados que sejam preparados ou fracionados em serviços de alimentação e comercializados no próprio estabelecimento;

II - alimentos embalados nos pontos de venda na presença do consumidor;

III - alimentos comercializados sem embalagens.

Art. 3ํㅜ Para efeito desta Resolução, são adotadas as seguintes definições:

I - alimento: toda substância que se ingere no estado natural, semiprocessada ou processada, destinada ao consumo humano, incluídas as bebidas, gomas de mascar e qualquer outra substância utilizada em seu processamento, preparo ou tratamento, excluídos os cosméticos, o tabaco e as substâncias utilizadas unicamente como medicamentos;

II - embalagem: recipiente, pacote ou invólucro destinado a proteger, conservar e ou facilitar o transporte e manuseio do alimento, podendo encobri-lo total ou parcialmente;

III - consumidor: toda pessoa física ou jurídica que adquire ou utiliza o alimento;

IV - painel principal ou vista principal: área visível em condições usuais de exposição onde estão escritas em sua forma mais relevante a denominação de venda, a marca e ou o logotipo se houver;

V - rotulagem: toda inscrição, legenda, imagem ou toda matéria descritiva ou gráfica que seja escrita, impressa, estampada, gravada, gravada em relevo ou litografada ou colada sobre a embalagem;

$\mathrm{VI}$ - serviço de alimentação: estabelecimento institucional ou comercial onde o alimento é manipulado, preparado, armazenado e ou exposto à venda, podendo ou não ser consumido no local, tais como: restaurantes, lanchonetes, bares, padarias, escolas, creches.

Art. 4ำ As seguintes fontes são reconhecidas por causarem alergias ou intolerâncias alimentares em pessoas sensíveis:

I - cereais que contêm glúten, nomeadamente trigo, centeio, cevada, aveia e suas estirpes hibridizadas;

II - crustáceos;

III - ovos;

IV - peixes;

$\mathrm{V}$ - amendoim;

VI - soja;

VII - leite;

VIII - amêndoa (Prunus dulcis);

IX - avelã (Corylus spp.);

$\mathrm{X}$ - castanha de caju (Anacardium occidentale)

XI - castanha do Brasil (Bertholletia excelsa);

XII - macadâmia (Macadamia spp.);

XIII - noz (Juglans spp.);

XIV - pecã (Carya illinoensis);

$\mathrm{XV}$ - pistache (Pistacia vera L.);

$X V I$ - sulfitos (dióxido de enxofre e seus sais) em concentração igual ou superior a 10 (dez) partes por milhão (ppm), expresso em dióxido de enxofre. 
Art. 5o As alterações na lista de fontes reconhecidas por causarem alergias ou intolerâncias alimentares podem ser realizadas mediante:

I - atualização das normas do Codex Alimentarius; ou

II - evidências científicas que demonstrem a relação de causa-efeito entre o consumo do alimento e o aparecimento de efeitos adversos, sua magnitude epidemiológica e sua severidade.

Art. 6ㅇ Os alimentos, ingredientes, aditivos alimentares, coadjuvantes de tecnologia e matérias-primas embalados na ausência dos consumidores, inclusive aqueles empregados na sua produção e os destinados aos serviços de alimentação, devem conter a declaração "Contém glúten" ou "Não contém glúten", conforme o caso.

$\S 1^{\circ} \mathrm{A}$ declaração "Não contém glúten" deve ser utilizada sempre que:

I - o alimento não seja constituído de trigo, centeio, cevada, aveia e suas estirpes hibridizadas;

II - o alimento não seja derivado de trigo, centeio, cevada, aveia e suas estirpes hibridizadas;

III - o alimento não seja adicionado intencionalmente de ingredientes, aditivos alimentares, coadjuvantes de tecnologia ou matérias-primas derivadas de trigo, centeio, cevada, aveia e suas estirpes hibridizadas; e

IV - a quantidade de glúten no alimento tal como exposto a venda seja inferior a 20 (vinte) ppm

$\S 2^{\circ}$ A declaração "Contém glúten" deve ser utilizada sempre que os requisitos estabelecidos no $\S 1^{\circ}$ - deste artigo não sejam atendidos.

$\S 3$ ㅇ Para os produtos destinados exclusivamente ao processamento industrial e ou aos serviços de alimentação, a informação sobre a presença ou ausência do glúten pode ser fornecida, alternativamente, nos documentos que acompanhem o produto.

$\S 4$ ㅇ O disposto neste artigo não se aplica aos alimentos para fins especiais para dietas com restrição de glúten, os quais devem atender à Portaria no 29 , de 13 de janeiro de 1998, que aprova o regulamento técnico referente a alimentos para fins especiais.

Art. $7^{\circ}$ Os alimentos que consistam, sejam derivados ou contenham adição intencional de ingredientes, aditivos alimentares, coadjuvantes de tecnologia ou matérias-primas derivados das fontes reconhecidas por causarem alergias ou intolerâncias alimentares descritas nos incisos II a XVI do art. 4ㅜㅡ, independentemente da quantidade, devem trazer a declaração "Alérgicos: Contém (nomes das fontes)" ou "Alérgicos: Contém derivados de (nomes das fontes)", conforme o caso.

$\S 1$ ㅇ A declaração a que se refere o caput não é obrigatória para os casos em que a denominação de venda mencione claramente a fonte reconhecida por causar alergia ou intolerância alimentar com pelo menos o tamanho de letra estabelecido no Anexo desta Resolução.

$\S 2^{\circ}$ Para os produtos destinados exclusivamente ao processamento industrial ou aos serviços de alimentação, a informação pode ser alternativamente fornecida nos documentos que acompanhem o produto.

$\S 3^{\circ}$ Os produtos derivados das fontes reconhecidas por causarem alergias ou intolerâncias alimentares podem ser dispensados da exigência da declaração de que trata o caput, desde que comprovada a ausência de potencial alergênico.

$\S 4^{\circ}$ A comprovação de que trata $\circ \S 3^{\circ}$ deste artigo deve ser solicitada mediante petição de exclusão de produtos da lista de fontes reconhecidas por causarem alergias ou intolerâncias alimentares, acompanhada da seguinte documentação:

I - estudos clínicos duplo-cegos e placebo controlados de consumo que confirmem que o produto especificado não causa reações alérgicas em pacientes com alergia clínica à fonte alimentar; e 
II - especificações do produto, laudos de análise laboratorial e descrição detalhada de seu processo de fabricação que atestem a consistência do seu controle de qualidade e segurança.

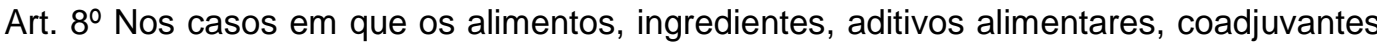
de tecnologia ou matérias-primas tenham risco de contaminação incidental pelas fontes reconhecidas por causarem alergias ou intolerâncias alimentares descritas nos incisos II a XV do art. $4^{\circ}$, deve constar no rótulo a declaração "Alérgicos: Pode conter (nomes das fontes)".

$\S 1^{\circ} \mathrm{O}$ disposto neste artigo não se aplica aos produtos que tenham a declaração prevista no art. $7^{\circ}$ para a fonte reconhecida por causar alergia ou intolerância alimentar.

$\S 2^{\circ}$ Para os produtos destinados exclusivamente ao processamento industrial ou aos serviços de alimentação, a informação pode ser alternativamente fornecida nos documentos que acompanhem o produto.

Art. 9o As declarações exigidas nos artigos $6^{\circ}, 7^{\circ}$ e $8^{\circ}$ desta Resolução devem estar agrupadas próximas à lista de ingredientes da rotulagem, em moldura de fundo branco e com caracteres de mesmo tipo e cor preta que atendam aos requisitos de altura estabelecidos no Anexo desta Resolução.

Parágrafo único. As declarações a que se refere o caput não podem estar dispostas em locais de difícil visualização, encobertos ou removíveis pelo lacre de abertura, como áreas de selagem e de torção.

Art. 10. A empresa deve encaminhar a documentação referente ao atendimento dos requisitos previstos nesta Resolução para fins de registro, quando aplicável, e mantê-la para consulta dos órgãos do Sistema Nacional de Vigilância Sanitária, quando solicitado.

Art. 11. Os estabelecimentos abrangidos por esta Resolução terão o prazo de 12 (doze) meses contados a partir da data de sua publicação para promover as adequações necessárias nos produtos que se enquadrem naqueles relacionados no art. $2^{\circ}$.

Parágrafo único. Os produtos fabricados até o final do prazo de adequação a que se refere o caput podem ser comercializados até o fim de seu prazo de validade.

Art. 12. O descumprimento das disposições contidas nesta Resolução constitui infração sanitária, nos termos da Lei no 6.437, de 20 de agosto de 1977, sem prejuízo das responsabilidades civil, administrativa e penal cabíveis.

Art. 13. Fica revogada a Resolução RDC o 40, de 8 de fevereiro de 2002, que aprova o regulamento técnico para rotulagem de alimentos e bebidas embalados que contenham glúten.

Art. 14. Esta Resolução entra em vigor na data de sua publicação.

DIRCEU APARECIDO BRÁS BARBANO

\section{Anexo}

Altura mínima dos caracteres para indicação da presença de substância que causam alergia ou intolerância alimentar

\begin{tabular}{|l|l|}
\hline Área da vista principal $\left(\mathbf{c m}^{2}\right)$ & Altura mínima dos caracteres (mm) \\
\hline Menor que 40 & 2 \\
\hline Maior ou igual a 40 e menor que 170 & 3 \\
\hline Maior ou igual a 170 e menor que 650 & 4,5 \\
\hline Maior ou igual a 650 e menor que 2600 & 6 \\
\hline Maior ou igual a 2600 & 10 \\
\hline
\end{tabular}

